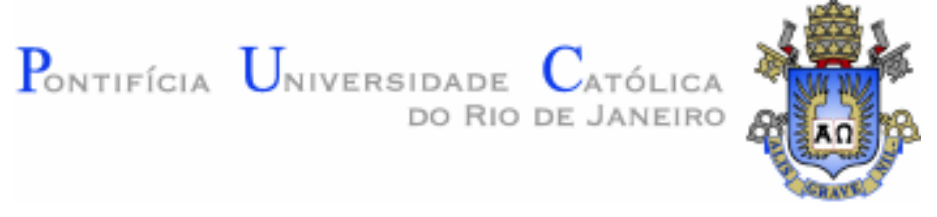

Bruno Portella Tassara

\title{
Um Jogo Multijogador Online para Identificação de Funções Executivas em Idosos
}

Dissertação de Mestrado

Dissertação apresentada como requisito parcial para a obtenção do grau de Mestre pelo Programa de Pós-graduação em Informática do Departamento de Informática da PUC-RIO.

Orientador: Prof. Bruno Feijó Co-Orientador DI: Antonio Luz Furtado Co-Orientadora PSI: Helenice Charchat Fichman 


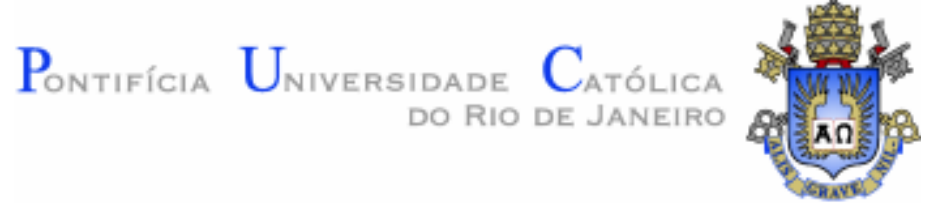

Bruno Portella Tassara

\section{Um Jogo Multijogador Online para Identificação de Funções Executivas em Idosos}

Dissertação de Mestrado

Dissertação apresentada como requisito parcial para a obtenção do grau de Mestre pelo Programa de Pós-Graduação em Informática da PUC-Rio. Aprovada pela Comissão Examinadora abaixo:

Prof. Bruno Feijó

Orientador

Departamento de Informática - PUC-Rio

Prof. Antônio Luz Furtado Co-Orientador Departamento de Informática - PUC-Rio

Profa. Helenice Charchat Fichman Co-Orientadora Departamento de Psicologia - PUC-Rio

Prof. Augusto Cesar Espíndola Baffa Departamento de Informática - PUC-Rio

Profa. Rosinda Martins Oliveira UFRJ

Rio de Janeiro 28 de Maio de 2021 
Todos os direitos reservados. A reprodução total ou parcial do trabalho é proibida sem a autorização do autor, do orientador e da universidade.

\section{Bruno Portella Tassara}

Graduou-se em Engenharia Eletrônica e de Computação pela UFRJ em 2009. Tem pós graduação em Engenharia de Petróleo pela Universidade Petrobras. Atuou em projetos envolvendo microscopia de força atômica no Laboratório de Fisica Biológica da UFRJ. Ingressou na Petrobras em 2009 como engenheiro de petróleo, tendo atuado no acompanhamento e controle da produção de campos produtores da Bacia de Campos. Participou dos projetos de desenvolvimento da produção do campo de Tupi. Atualmente dedica-se a automação de simuladores de fluxo multifásico e temas de transformação digital dentro da Petrobras.

Ficha Catalográfica

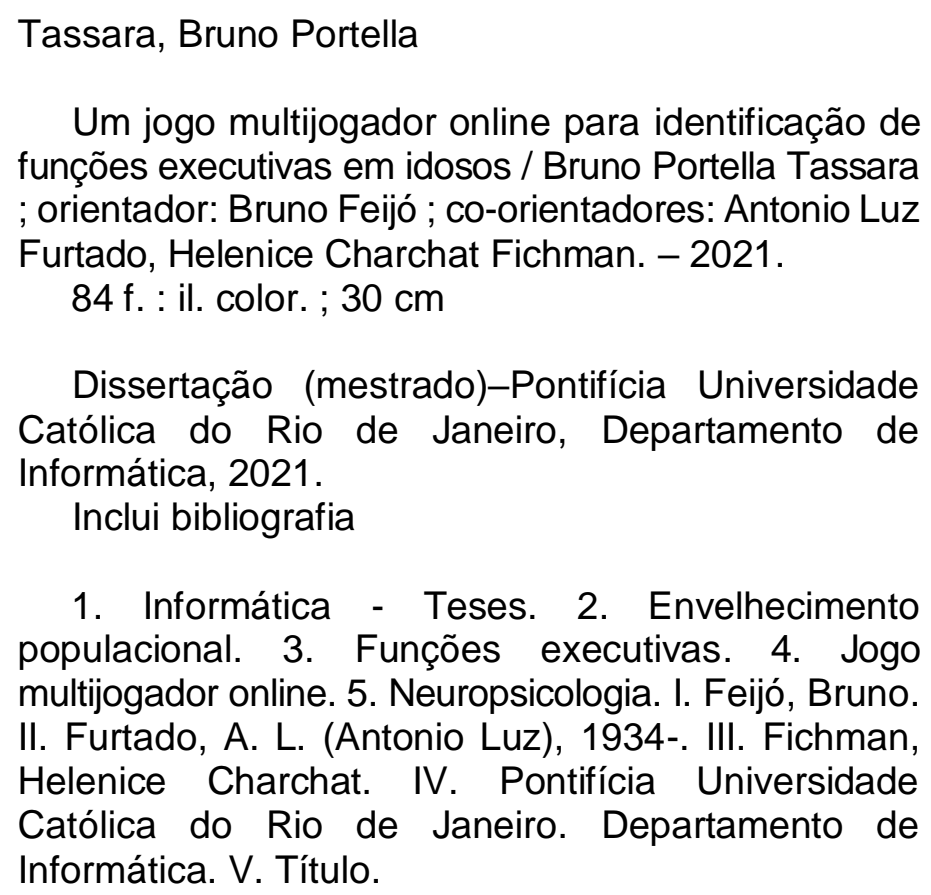

1. Informática - Teses. 2. Envelhecimento populacional. 3. Funções executivas. 4. Jogo multijogador online. 5. Neuropsicologia. I. Feijó, Bruno. II. Furtado, A. L. (Antonio Luz), 1934-. III. Fichman, Helenice Charchat. IV. Pontifícia Universidade Católica do Rio de Janeiro. Departamento de Informática. V. Título. 


\section{Agradecimentos}

À minha mãe e ao meu pai por terem despertado em mim o interesse pelos estudos e terem me ensinado que o saber é a única coisa que não podem tirar de alguém. À minha esposa, Fabiana, por todo o apoio, muitas vezes sacrificando seu próprio trabalho para que eu tivesse algumas horas livres para dedicar ao mestrado. Aos meus filhos Enzo e Bento pela compreensão que tiveram em me deixar trancado trabalhando quando queriam estar comigo. Aos meus filhos Enzo e Bento pelas vezes que invadiram o escritório e me impediram de trabalhar para ficar com eles. Aos meus amigos Sérgio e Marcelo por defenderem a retaguarda e o front quando precisei de tempo para os estudos. Agradeço imensamente e repetidamente ao meu orientador Professor Bruno Feijó por todos os conselhos, ajudas, empurrõezinhos e injeções de ânimo quando fraquejei. Ao meu coorientador Professor Antônio Furtado, pelos sábios conselhos e tiradas inteligentes. À minha coorientadora Professora Helenice Fichman, por prover orientação enquanto navegávamos por águas desconhecidas. Às nossas ajudantes Dora e Rose, por todo o suporte que deram com as crianças, tornando os momentos em que não pude lhes dar a devida atenção menos difíceis para eles. Agradeço a Deus e à Petrobras pela oportunidade. O presente trabalho foi realizado com apoio da Coordenação de Aper feiçoamento de Pessoal de Nível Superior - Brasil (CAPES) - Código de Fi nanciamento 001 


\section{Resumo}

Tassara Bruno Portella; Feijó Bruno. Um Jogo Multijogador Online para Identificação de Funções Executivas em Idosos. Rio de Janeiro, 2021. 88p. Dissertação de Mestrado - Departamento de Informática, Pontifícia Universidade Católica do Rio de Janeiro.

O envelhecimento cada vez mais acentuado das populações no Brasil (1) e no mundo (2) tem tornado mais evidente o problema do declínio cognitivo em idosos. Com o passar dos anos, alguns indivíduos podem apresentar a perda da capacidade de resolver novos problemas, ou de se adaptar a imprevistos. Na Neuropsicologia, as chamadas Funções Executivas são responsáveis pelo desempenho do indivíduo neste tipo de situação. Para detectar este tipo de dificuldade, mesmo em suas fases iniciais, há diversas baterias de testes que o psicólogo pode aplicar. E, como suporte ao tratamento, várias atividades podem estimular estas funções e melhorar o desempenho cognitivo. No mundo dos jogos digitais, diversos são os aplicativos que prometem treinar o cérebro, mas em geral estes games consistem de uma série de pequenas atividades isoladas. Há um consenso na comunidade científica de que a interação social é benéfica para a saúde mental dos idosos. A diversidade de situações enfrentadas pelo indivíduo neste tipo de interação garante que, entre outros benefícios, as habilidades de Atualização, Alternância e Inibição sejam treinadas, melhorando as funções executivas do idoso.

Este trabalho propõe a criação de um jogo sério (serious game), porém lúdico e divertido, para identificação da perda de eficiência no uso das Funções Executivas e, possivelmente, no treinamento das mesmas. O atrativo do jogo está na flexibilidade e intensidade das tarefas propostas, que se inserem em uma narrativa lúdica e contêm atividades usuais do dia a dia das pessoas. O tema de planejar e realizar uma festa virtual de 80 anos mostra-se particularmente adequado para a investigação em questão e permite a utilização de imprevistos nas tarefas propostas. Quanto ao planejamento da reatividade emocional dos idosos, o jogo permitirá que a dificuldade e o nível de imprevistos sejam ajustados de forma a evitar qualquer tipo de estresse ao idoso. O nível de dificuldade das tarefas e diversos outros ajustes 
podem ser feitos por um participante que age como controlador ou mediador do jogo, papel possivelmente exercido por um psicólogo. Outra novidade desta proposta é a implementação de um jogo em modo multiplayer, tornando-se possível observar o papel da interação social no diagnóstico e no tratamento do déficit cognitivo, ou mesmo, a relação entre a disposição do indivíduo em participar de atividades sociais e a perda de funções executivas.

\section{Palavras Chave}

Envelhecimento Populacional; Funções Executivas; Jogo Multijogador Online; Neuropsicologia. 


\section{Abstract}

Tassara Bruno Portella; Feijó Bruno. An Online Multiplayer Game for Identifying Executive Functions in Older Adults. Rio de Janeiro, 2021. 88p. Dissertação de Mestrado - Departamento de Informática, Pontifícia Universidade Católica do Rio de Janeiro.

The increasingly accentuated aging of populations in Brazil (1) and the world (2) has made the cognitive decline in the elderly more evident. As the years go by, some individuals may lose the ability to solve new problems or adapt to unforeseen events. In Neuropsychology the Executive Functions of the Brain (EF) are responsible for the performance in this kind of tasks.

The loss of efficiency in the Executive Functions is a natural result of the aging process. However, excessive loss of EF can lead to Mild Cognitive Impairment and, in more advanced stages, to neurodegenerative diseases, such as Alzheimer's disease. To detect this kind of impairment, even in its initial stages, there are several test bateries that the psychologist can apply. And, as support for treatment, several activities can stimulate these functions and improve cognitive performance. In the world of digital games, many applications promise to train the brain, but most of these games consist of small isolated tasks. There is a consensus in the scientific Community that social interaction is beneficial to the mental health of old individuals. The diversity of situations faced by the individual in this kind of interaction guarantees that, among other benefits, abilities such as Actualization, Alternance and Inibition are trained, helping improve the executive functions of the elderly.

This work proposes creating a serious game, yet ludic and fun, to help identify the loss of efficiency in the use of Executive Functions and, possibly, in their training. The game's lure is in its flexibility and the intensity of the quests presented to the player. These quests are part of a ludic narrative about everyday activities, such as getting groceries at the market or finding candles for a birthday cake. The game's central theme is to collaborate to the realization of the 80 -year birthday 
party of a friend. As for the emotional reactivity of the old adults that engage the game, it was built with the option to regulate de difficult level. The difficult level that each player faces and several other aspects of the game can be configured by a person that acts as controller or mediator of the game, probably a psychologist. Another innovation of this proposal is implementing the game as a multiplayer game, making it possible to observe the social interaction factor in diagnosing and treating cognitive deficit. Or even the relation between the individual's disposition to engage in social activities and the loss of executive functions.

\section{Keywords}

Populational Aging; Executive Functions; Online Multiplayer Game; Neuropsychology. 


\section{Sumário}

1 Introdução 10

2 Trabalhos Relacionados $\quad 18$

3 Psicologia Cognitiva, Neuropsicologia e Funções Executivas 27

3.1 Cognição 27

$\begin{array}{ll}3.2 \text { Psicologia Cognitiva } & 27\end{array}$

$\begin{array}{ll}3.3 \text { Neuropsicologia } & 28\end{array}$

3.4 Declínio Cognitivo com a Idade Avançada 29

3.5 Funções 30

3.5.1 Memória de Trabalho 32

3.5.2 Flexibilidade Cognitiva 33

3.5.3 Autocontrole Emocional 34

3.5.4 Atenção Seletiva 35

3.5.5 Planejamento 35

3.5.6 Monitoração 36

4 Conceitos, Estrutura e Uso do Jogo Proposto 37

4.1 Bem-Vindo a Lugares Divertidos 37

4.2 Conceito do Psicólogo como Controlador 39

4.3 Multijogador Online 41

4.4 Personagens 42

4.5 Tutorial de Reconhecimento e de Movimentação 44

4.6 Missão principal 45

4.7 Lista de Itens 46

$\begin{array}{ll}4.8 \text { Barra de Energia } & 47\end{array}$

4.9 Itens Compostos e Itens com Prioridade 48

4.10 Bônus em Créditos 48

4.11 Busca pelos Amigos 49

4.12 Aquisição de Itens 49 
$\begin{array}{ll}4.13 \text { Conclusão do Jogo } & 50\end{array}$

4.14 Elementos de Distração $\quad 51$

4.15 Imprevistos $\quad 51$

4.16 Missões e Funções Executivas 52

4.17 Game Analytics $\quad 54$

4.18 O protótipo e as métricas utilizadas 56

5 Sistema Computacional 59

5.1 Networking $\quad 59$

5.2 Mirror Networking 62

5.3 Diagrama de Classes 63

$\begin{array}{ll}5.4 \text { Scripts } & 64\end{array}$

$\begin{array}{ll}5.5 \text { Animações } & 67\end{array}$

6 Resultados alcançados $\quad 69$

7 Conclusões e Trabalhos Futuros 76

7.1 Conclusões 76

$\begin{array}{ll}\text { 7.2 Trabalhos Futuros } & 77\end{array}$

$\begin{array}{ll}\text { Referências } & 80\end{array}$ 


\section{Lista de Figuras}

Figura 1: Evolução da Pirâmide Etária Brasileira 10

Figura 3: Atividade de arrumar as malas no jogo usado por de Kraczyk (15) 19

Figura 4: Atividade de navegar pelo metro no jogo usado por de Kraczyk (15) 20

Figura 5: Funcionamento do sistema de realimentação neurológica (13) 21

Figura 6: Jogos utilizados no treinamento neurológico: (A) Run, (B) Sun Shine Day, (C) Cast Away, (D) Paper Plane e (E) Shoot (13)

Figura 7: (A) Mapa do Jogo. (B) Mago maldoso roubando o tesouro do reino.

(C) Protagonista. (D) Teste Stroop. (E) Pontuação adicionada na forma de poder mágico. (F) Batalha Final. (19)

Figura 8: Game desenvolvido para testar se a imersão resulta em melhores desempenhos nos testes (12)

Figura 9: Regiões do cérebro e suas funções. (7) (fonte: In Search of the Human Mind, por Robert J. Sternberg)

Figura 10: Cérebro Normal X Cérebro com Alzheimer (32)

Figura 11: Dimensional Change Card Sorting (fonte: https://en.wikipedia.org/wiki/ Cognitive_flexibility\#/media/File:Dimensional_Change_Card_Sorting_Task.jpg)

Figura 12: Vista aérea da cidade

Figura 13: Interior de uma das casas visitáveis 38

Figura 14: Visão em primeira pessoa 39

Figura 15: Configurações iniciais do psicólogo ou controlador do jogo 40

Figura 16: Mensagem do psicólogo ao jogador 41

Figura 17: Visão aérea do psicólogo ou controlador durante uma partida 41

Figura 18: Tela de seleção de personagem. 43

Figura 19: Personagens controlados pelo computador (NPCs - Non-Player Characters) 43

Figura 20: Personagens dos jogadores 44

Figura 21: (a) Tela de seleção dos personagens. (b) Tutorial de Reconhecimento 44

Figura 22: Tela de recebimento da missão 46

Figura 23: Cena de Sobrevoo $\quad 46$

Figura 24: Lista de itens exibida na tela $\quad 47$

Figura 25: Interface mostrando sorvete derretendo e outros indicadores 48

Figura 26: Seta apontando para jogador mais próximo 49

Figura 27: Máquina do cartão de crédito $\quad 50$

Figura 28: Festa ao final de uma partida

Figura 29: Família de soluções de rede do Photon 61

Figura 30: Modelo de conexão do Mirror (fonte: do autor) 62

Figura 31: Diagrama de Classes (WIP) 64

Figura 32: Controlador de Animação dos personagens dos jogadores, usando
a interface do Unity

Figura 33: Teste com 3 instâncias no mesmo computador $\quad 69$

Figura 34: Desempenho Gráfico no teste com 3 instância $\quad 70$

Figura 35: Uso intenso de mesh colliders, o que reduz o desempenho do processamento 72

Figura 36: Teste de latência $\quad 74$ 


\section{Introdução}

Além da doença de Alzheimer, o comprometimento cognitivo leve (CCL) é uma entidade nosológica ${ }^{1}$ que tem grande prevalência na população idosa. Este conceito mostra uma fase de possível transição entre o declínio cognitivo esperado para o processo de envelhecimento e um processo demencial. (3) (4)

O tema se mostra relevante pois afeta uma grande parte da população e não se restringe a idosos aposentados. $\mathrm{O}$ aumento da expectativa de vida tem tornado cada vez mais frequente a presença de pessoas de idade avançada no mercado de trabalho. A evolução da pirâmide etária esperada do Brasil é uma prova contundente do tema (Figura 1). Melhorar o desempenho cognitivo destes indivíduos, além de ser um problema de saúde pública, se mostra benéfico às empresas por duas razões: (i) aumenta a eficiência de seus colaboradores mais idosos e experientes; (ii) contribui para uma aposentadoria saudável de seus funcionários, o que está alinhado com a prática da responsabilidade social das corporações modernas.

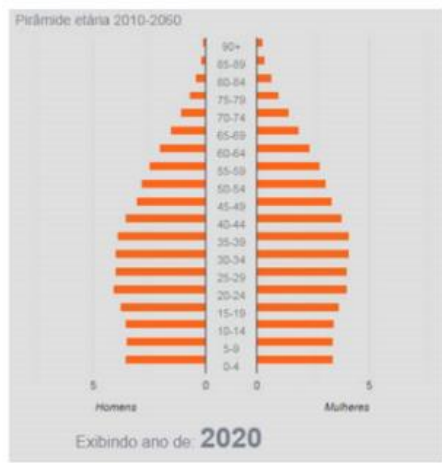

a

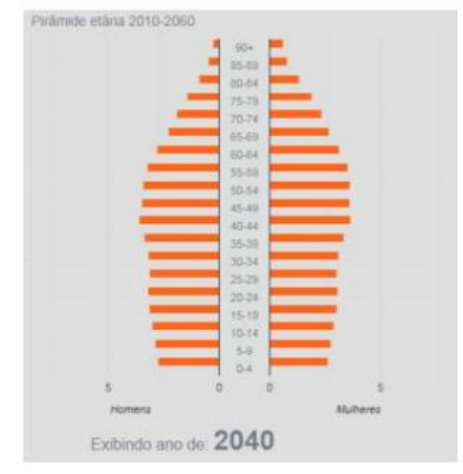

b

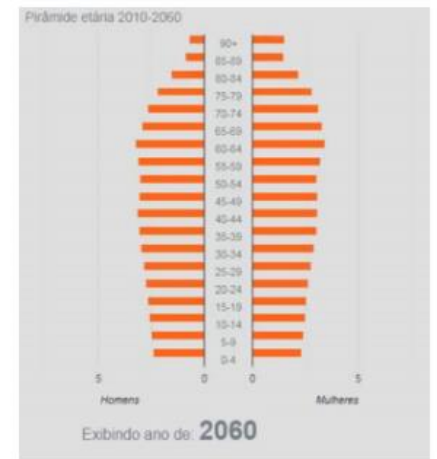

C

Figura 1: Evolução da Pirâmide Etária Brasileira

Dentro do campo da neuropsicologia, um dos aspectos muito importantes quanto à saúde mental de um indivíduo são as chamadas Funções Executivas (FE) (5) (6) (7). Estas habilidades são responsáveis pela capacidade de um indivíduo de realizar atividades do dia a dia, indispensáveis à sua vida, desde compreender a leitura de um texto (8), até andar pelo mercado colocando itens da lista de compras no carrinho. As FE englobam o controle cognitivo para realizar um objetivo específico, permitindo que o indivíduo defina metas, inicie ações, iniba outras,

\footnotetext{
${ }^{1}$ Nosologia é o ramo da ciência médica que trata da classificação das doenças.
} 
planeje, alterne e monitore resultados. Estas funções são diretamente afetadas em idosos com déficit cognitivo, como aqueles acometidos pela doença de Alzheimer por exemplo. São Funções executivas:

- Memória de Trabalho - Capacidade de manter de forma transitória uma informação verbal ou visuoespacial necessárias para realização de uma atividade.

- Autocontrole Emocional- Capacidade de superar um obstáculo ou desafio que promova uma reatividade emocional.

- Atenção Seletiva-Capacidade de focar em uma atividade específica e inibir estímulos de distração.

- Flexibilidade Cognitiva - Capacidade de mudar o procedimento necessário para realizar uma tarefa em função de algum imprevisto

- Planejamento - Capacidade de organizar e planejar os passos necessários para a realização de uma determinada atividade.

Há ainda muitas outras funções executivas, como por exemplo: Iniciativa, Fluência Verbal, Atenção Seletiva Dividida e Alternada, Cognição Social, Regulação Emocional do Comportamento. Ainda assim, esta lista não é exaustiva, havendo ainda outras funções a depender do autor. No entanto, as funções aqui destacadas são as mais comumente citadas. (9) (5)

Nos dias atuais, há uma pressão cada vez maior da sociedade, dos empregadores, e de praticamente todos os lados para que o indivíduo seja mais eficiente, mais rápido e mais ágil em todos os aspectos de sua vida. Este anseio coletivo pela eficiência colaborou para a extraordinária variedade de pequenos aplicativos de celular que prometem aumentar, melhorar, treinar e catapultar o cérebro. A esmagadora maioria destes ditos treinos do cérebro consiste de pequenos jogos de memória e de velocidade de raciocínio. Embora possam dar uma falsa impressão de progresso ao transitar pelos níveis do jogo, não necessariamente eles estão deixando o jogador mais inteligente, eficiente ou mesmo treinando as funções executivas.

No levantamento bibliográfico e de aplicativos, foram encontrados diversos trabalhos dedicados a medir as capacidades cognitivas, avaliar funções executivas, diagnosticar declínio cognitivo em pessoas de mais idade, como também a propor treinamentos para melhorar as capacidades cognitivas de um indivíduo. Muitos 
destes trabalhos recorrem a jogos simples, que acessam uma ou outra habilidade específica do cérebro. Este tipo de abordagem, embora em muitos casos tenha se mostrado eficiente, carece de contexto, pois é feito sem ter relação direta com a vida diária do indivíduo.

As funções executivas são uma parte importantíssima do processo cognitivo do indivíduo e são acessadas constantemente ao longo de um dia normal, como quando se organiza mentalmente os itens a buscar na geladeira para o café da manhã, passando pelo ato de dirigir até o trabalho e até o momento do retorno para casa, quando não se pode esquecer de passar na padaria para buscar o pão. Uma abordagem contextualizada em atividades normais da vida de uma pessoa saudável tem grande potencial de mensurar ou mesmo treinar as FE com sucesso (10).

Segundo a professora Sabine Doebel da George Mason University: "Treinamentos cerebrais não vão melhorar suas funções executivas em um aspecto amplo pois envolvem se exercitar de maneira restrita, fora do contexto da vida real, na qual nós realmente usamos as funções executivas. Se você realmente quer melhorar suas funções executivas, você precisa entender como elas são afetadas pelo contexto.”. (11)

Por estas razões, o contexto é um dos dois pilares em que o jogo Lugares Divertidos, desenvolvido no presente trabalho, se apoia. Por meio do contexto da vida diária espera-se obter sucesso em avaliar as funções executivas do cérebro e, em um futuro próximo, até mesmo treiná-las. A proposta do jogo é levar o jogador para uma situação lúdica, mas não completamente alheia ao seu dia a dia. Para isso, Lugares Divertidos, trata da preparação para uma festa de aniversário, para a qual o jogador deve assumir o controle de um avatar e andar por uma cidade nova e desconhecida, buscando os itens necessários para a realização da festa. A cidade por onde o jogador viaja, é calma e agradável e contém casas, piscinas, postos de gasolina e até mesmo um shopping center. Durante o jogo, diversas atividades podem ser usadas para avaliar funções executivas. Na versão atual, o jogo está implementado para ser apenas uma forma de medição das funções executivas, mas estabeleceu-se o terreno para que, em versões futuras, o jogo possa ser usado para o treinamento destas funções. Todas as atividades do jogo são inseridas assim como ocorrem no dia a dia de uma pessoa, tais como fazer a conta de quanto precisa pagar, já que um pote de sorvete custa 5 unidades monetárias e o jogador precisa levar 3 
potes de sorvete para a festa (memória de trabalho); ou ter a necessidade de seguir as instruções do vendedor da loja, que pode informar ao jogador que o sorvete acabou, mas que ele vai encontrar mais no posto de gasolina no final da rua (flexibilidade cognitiva). Outros aspectos do jogo se somam a este, como por exemplo a necessidade de monitorar a vitalidade do avatar (que pode se "cansar" e começar a andar devagar) e a possibilidade de interagir com o cenário (e.g., fazer um gato sair correndo de baixo de um carro ao clicar nele). Este ambiente - lúdico, complexo, familiar ao dia a dia de um indivíduo - é o primeiro diferencial de Lugares Divertidos.

O segundo pilar em que Lugares Divertidos se apoia é o da socialização. O ser humano é coletivo por natureza. Busca-se instintivamente a companhia de outros quando se está amedrontado ou sozinho. Humanos formam grupos desde a préhistória para garantir a sobrevivência e, em muitos casos, ficam deprimidos quando privados do convívio social (vide cenário atual do mundo hoje). A interação social é um aspecto importante da saúde mental do indivíduo. O convívio social no dia a dia de um adulto ajuda a manter o cérebro saudável. A exposição natural que este convívio traz a novas situações, imprevistos e ajustes é um campo fértil para o uso de funções executivas. Infelizmente, com a tendência de alguns idosos de se isolarem, seja por dificuldade de locomoção, seja pela aposentadoria e consequente saída do mercado de trabalho, o exercício natural das funções executivas fica reduzido.

Baseando-se neste pilar de socialização, Lugares Divertidos é um jogo multijogador online. A atividade de busca de objetos para a realização da festa é feita simultaneamente com outros jogadores. A interação social entre eles é encorajada por meio de bonificações como velocidade de movimento aumentada, acréscimo de pontuação do jogo e aumento do dinheiro disponível para obter itens. A disposição do indivíduo para este tipo de interação pode ser medida por diversos fatores, como quantidade de vezes que o botão que fornece uma dica da localização do jogador mais próximo é acionado.

Com base nestes dois pilares (contexto e socialização), Lugares Divertidos traz o jogador para um mundo lúdico e aberto a interações sociais, que pode ser diferente, mas que não está fora de contexto em relação ao dia a dia do idoso. Estas características não são encontradas em jogos de exercícios mentais oferecidos pela indústria. 
Do ponto de vista técnico, o jogo foi desenvolvido usando a Engine Unity combinada com diversos assets (componentes adicionais, adquiridos ou gratuitos). Estes assets consistem de bibliotecas para a implementação do modelo online do jogo (cliente-servidor) ou modelos 3D usados para os personagens e para a ambientação. Um modelo demonstração de um destes pacotes foi usado descrevendo a própria cidade onde ocorrem as aventuras dos personagens. Embora a arquitetura original do jogo seja no modelo cliente-servidor com um dos clientes agindo como host, o jogo pode facilmente ser modificado para rodar em uma arquitetura de servidor dedicado e com funcionalidades de matchmaking ${ }^{2}$, caso chegue a ser disponibilizado para o público em geral.

O Jogo desenvolvido e abordado neste trabalho é o primeiro protótipo do Lugares Divertidos e deve funcionar como uma prova de conceito. O grande objetivo aqui é torná-lo disponível para o uso controlado por profissionais da psicologia, que podem atuar como um "mestre do jogo", controlando diversos aspectos da jogabilidade e supervisionando a participação dos jogadores. Tanto quanto sabemos, nenhum outro jogo online para avaliação psicológica, no mercado ou na academia, implementa esta funcionalidade de ajuste e controle. Na sua primeira versão, espera-se que Lugares Divertidos sirva como uma ferramenta de avaliação de funções executivas em idosos, bem como de coleta de dados. A avaliação se baseia em cálculos realizados com os dados coletados, de forma a quantificar o desempenho em cada função executiva avaliada. Futuramente, com uso do jogo tanto por pacientes saudáveis quanto por pacientes com declínio cognitivo, espera-se calibrar melhor as fórmulas propostas e traçar-se uma linha de base que ajude a identificar alterações e desvios nas funções executivas, podendo assim, o próprio jogo detectar pacientes com declínio cognitivo. Em versões futuras do jogo, espera-se poder "treinar" as funções executivas do cérebro e possivelmente diagnosticar déficit cognitivo em seus diferentes graus.

Este trabalho encontra-se assim distribuído. O capítulo 2 trata de trabalhos relacionados, que utilizam jogos com os objetivos desta dissertação, alguns focados no diagnóstico e alguns focados no treinamento de funções executivas. Em seguida, no capítulo 3, é feita uma abordagem dos conceitos de Psicologia Cognitiva e de

\footnotetext{
${ }^{2}$ Matchmaking é o processo de conectar os jogadores para sessões de jogo online. A principal tarefa de um sistema de matchmaking é encontrar outra pessoa disposta a jogar (45).
} 
Neuropsicologia que nortearam o desenvolvimento das mecânicas do jogo. Nesse capítulo, disserta-se mais detalhadamente sobre o funcionamento do cérebro e das funções executivas e são abordadas metodologias para identificar e treinar tais funções. Na sequência, o capítulo 4 mostra os conceitos e estrutura do jogo, abordando o gameplay, as missões e todas as formas de interação do jogador com o jogo. Esse capítulo também aborda como as funções executivas discutidas no capítulo anterior são tratadas durante uma partida. Dando continuidade, a parte da computação é apresentada no capítulo 5, onde as tecnologias utilizadas, arquitetura do sistema, classes e implementação do jogo são discutidas. Esse capítulo também discute a questão de quais dados devem ser coletados para a avaliação das funções executivas. A seguir, o capítulo 6 mostra o estado atual do jogo desenvolvido, ilustrando algumas cenas do jogo e propondo métricas, a serem mais precisamente calibradas com o uso do protótipo, para mensurar as funções executivas. O capítulo 7 conclui o trabalho e lança algumas ideias de como o jogo pode evoluir para uma solução completa que, futuramente, espera-se poder auxiliar no treino de funções executivas e na melhoria da qualidade de vida das pessoas, se possível tornando-se um jogo amplamente distribuído. 


\section{Trabalhos Relacionados}

No levantamento bibliográfico e de aplicações, foram encontrados trabalhos relacionados, envolvendo jogos com finalidade análoga à da presente dissertação, que podem ser classificados em dois tipos de ênfase de abordagem: os que tratam de aspectos de treinamento cognitivo e os que tratam da coleta de dados. De todo modo, o levantamento realizado deixou clara a expectativa que já se tinha de que a parceria entre a psicologia e a informática pode ser muito frutífera e benéfica para o avanço nos tratamentos mitigadores do declínio cognitivo, como pode ser visto em mais detalhes em (12) (13) (14).

No trabalho de Valladares et al. (12), o uso de jogos digitais foi combinado com aprendizado de máquina (Machine Learning) para permitir a detecção precoce do declínio cognitivo e da doença de Alzheimer. Este trabalho propôs uma bateria de testes chamada Panoramix, que consistiu de uma série de jogos sérios (serious games) com o intuito de detectar marcadores, tais como funções executivas, atenção e memória. A proposta da bateria de testes Panoramix é ser uma alternativa aos testes tradicionais que consomem tempo e são afetados por distorções na percepção, como nos testes que consistem em questionários respondidos pelo idoso ou por um acompanhante. Os resultados apontaram uma taxa de 100 por cento de sucesso em diferenciar indivíduos que sofrem de Alzheimer e comprometimento cognitivo leve (CCL) de indivíduos saudáveis. Ainda de autoria de Valladares, o jogo sério Episodix (Error! Reference source not found.) foi usado, em combinação com mais dois jogos e com a utilização de aprendizado de máquina, para classificar os indivíduos em três categorias: saudáveis, com déficit cognitivo leve e com Mal de Alzheimer. Os jogos foram administrados de forma a reproduzir o CVLT (California Verbal Learning Test), mas usando um jogo sério em vez de papel e caneta. A validade dos jogos sérios foi testada por comparação com testes clássicos de avaliação cognitiva e foram usadas métricas amplamente usadas em estudos médicos como a medida F1, Coeficiente Kappa de Cohen, revocação e precisão. As variáveis coletadas para avaliação, em sua maioria, têm relação com a quantidade de erros, repetições ou omissões por parte do jogador. 


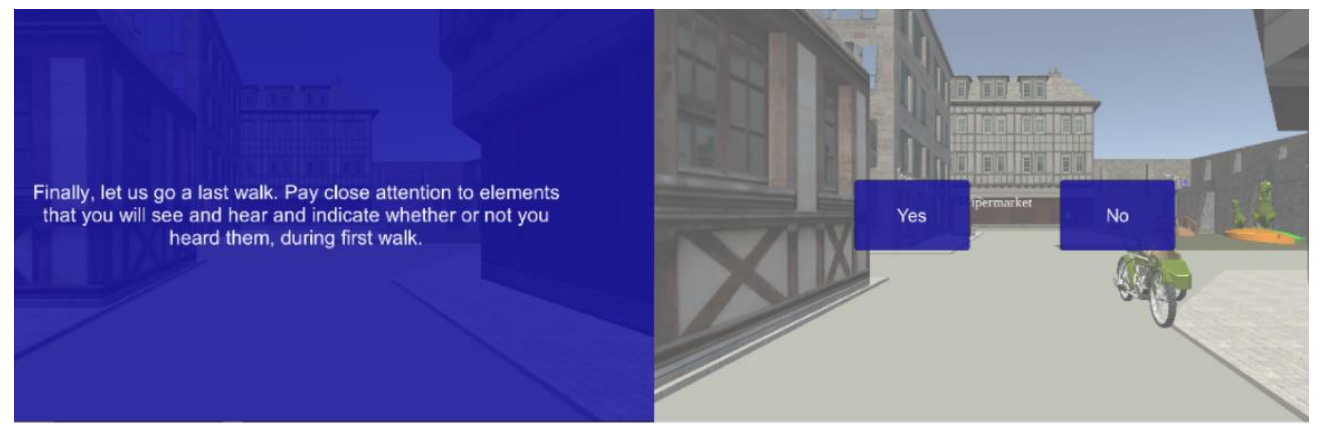

:O trabalho de Kraczyk (15) usou um jogo com contexto de atividades diárias, como a arrumação de uma mala para uma viagem, a navegação por estações de metrô e ida a museus, para treinar as funções executivas de pacientes com traumas cerebrais crônicos. Este foi um dos únicos trabalhos onde o contexto com o dia a dia foi observado e também foi aquele que mostrou a melhor qualidade gráfica do jogo (Figura 2 e Figura 3).

\section{PACKING FOR A TRIP:}

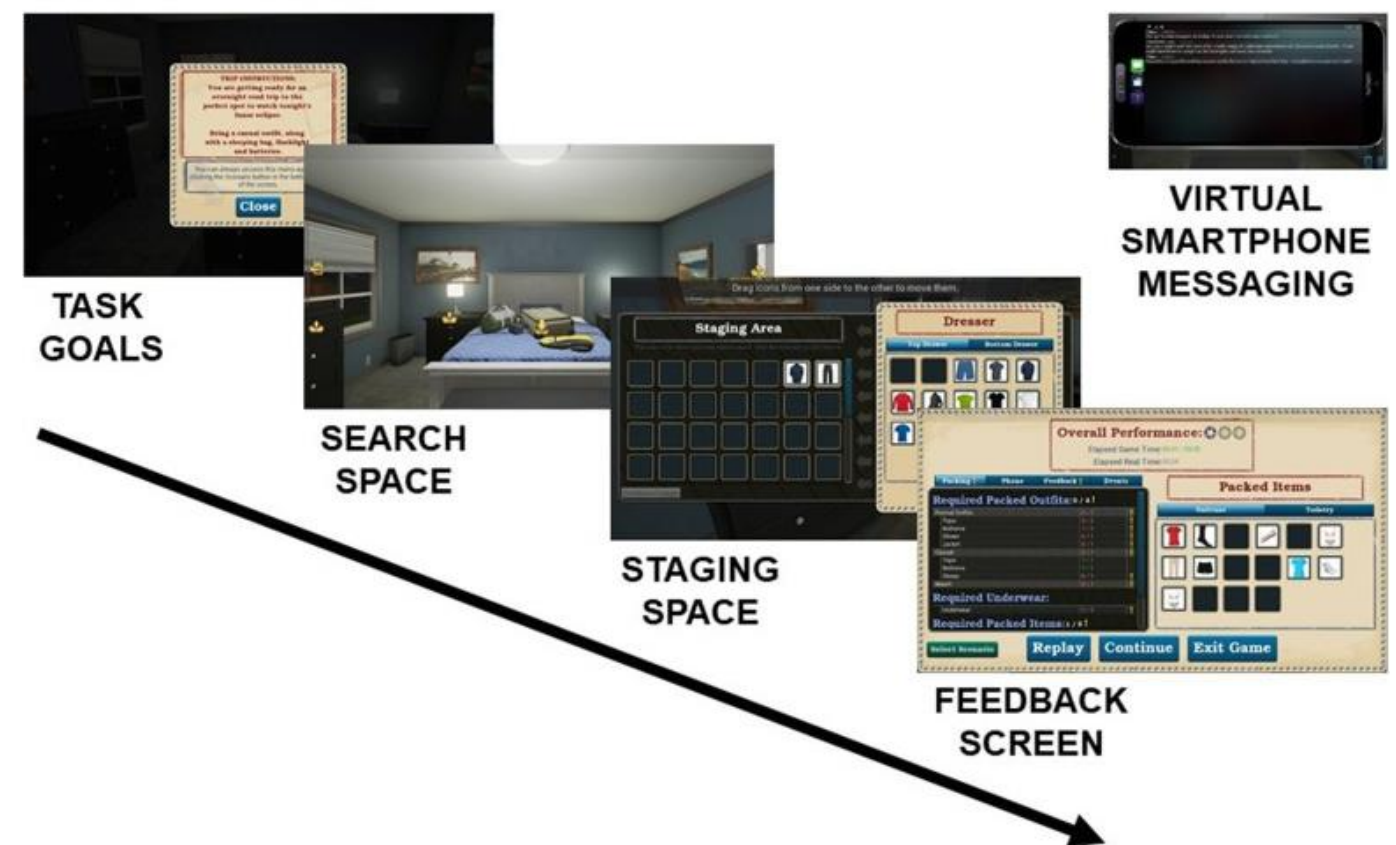

Figura 2: Atividade de arrumar as malas no jogo usado por de Kraczyk (15) 
GETTING AROUND TOWN:

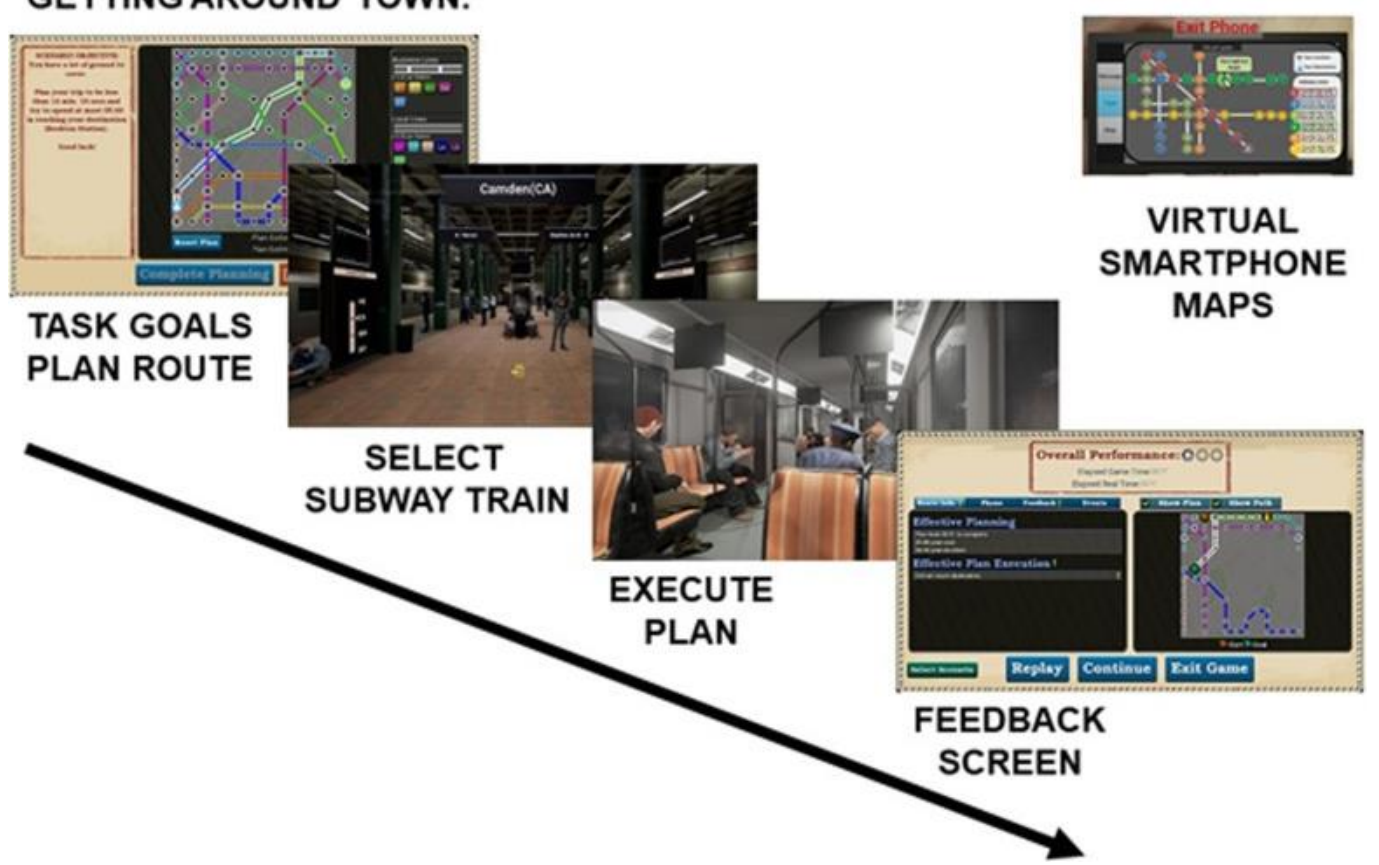

Figura 3: Atividade de navegar pelo metro no jogo usado por de Kraczyk (15)

Parong (16) mostrou que foi possível melhorar significativamente a performance de estudantes em tarefas que envolviam atenção seletiva, usando um jogo especialmente desenvolvido para o treino desta função executiva. A comparação foi feita com um grupo de jogadores que jogou outro jogo, não desenvolvido especificamente para tanto.

Hagler (17) implementou uma versão computadorizada do Teste de Trilhas (TMT) e desenvolveu um modelo computacional do teste, baseado em uma decomposição em diversos processos independentes. Este modelo tem com o objetivo estimar a performance do jogador no TMT e, assim, ajudar na detecção precoce do déficit cognitivo.

Bonnechère et al. (13) usaram jogos de dispositivos móveis para medição da capacidade cognitiva de idosos com e sem déficit cognitivo. Este trabalho focou na proliferação de jogos para o treino do cérebro. Segundo estes pesquisadores, há muita falta de informações que relacionem o desempenho nestes jogos com o desempenho cognitivo dos pacientes. Foi feita uma correlação de 7 jogos de dispositivos móveis com o desempenho no MMSE (Mini Mental State Exam) e com o ACE-R (Addenbrooke's Cognitive Evaluation revised). O trabalho concluiu que o uso dos jogos testados poderia ser uma alternativa ao MMSE e ao ACE-R, para avaliar as funções cognitivas, pelo menos quando o MMSE for maior do que 20/30. 
Ainda com o foco em jogos, o trabalho de Jirayucharoensak et al. (14) usou um sistema de treinamento baseado em um jogo com feedback neurológico para melhorar o desempenho cognitivo de idosos saudáveis e em pacientes com déficit cognitivo amnésico leve. O sistema utiliza um dispositivo de eletroencefalograma (EEG) portátil e 5 jogos desenvolvidos para aumentar a atenção e a performance cognitiva. O nível de atenção foi medido a partir do espectro de potência de ondas Alpha e Beta. O estudo tratou um grupo de mulheres idosas com déficit cognitivo amnésico leve e um grupo saudável. Todos os pacientes receberam o tratamento convencional para este distúrbio e uma parcela dos grupos foi tratada com o sistema baseado nos jogos. Os resultados mostraram que o uso dos jogos, conjugado ao tratamento convencional, foi mais eficaz do que o tratamento convencional na melhoria da atenção sustentada e da memória espacial de trabalho. Porém, este trabalho não mostrou resultado para melhorar o reconhecimento de padrões e a memória visual de curto prazo. No entanto, isto pode ser um resultado do tipo de jogo utilizado e não da metodologia de retroalimentação neurológica. A Figura 4 e a Figura 5 mostram, respectivamente, o sistema de retroalimentação e os jogos utilizados em (13).

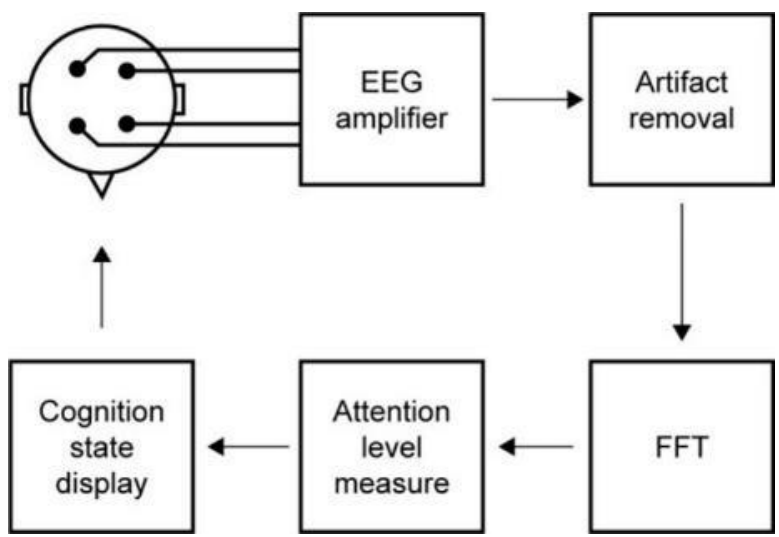

Figura 4: Funcionamento do sistema de realimentação neurológica (13) 


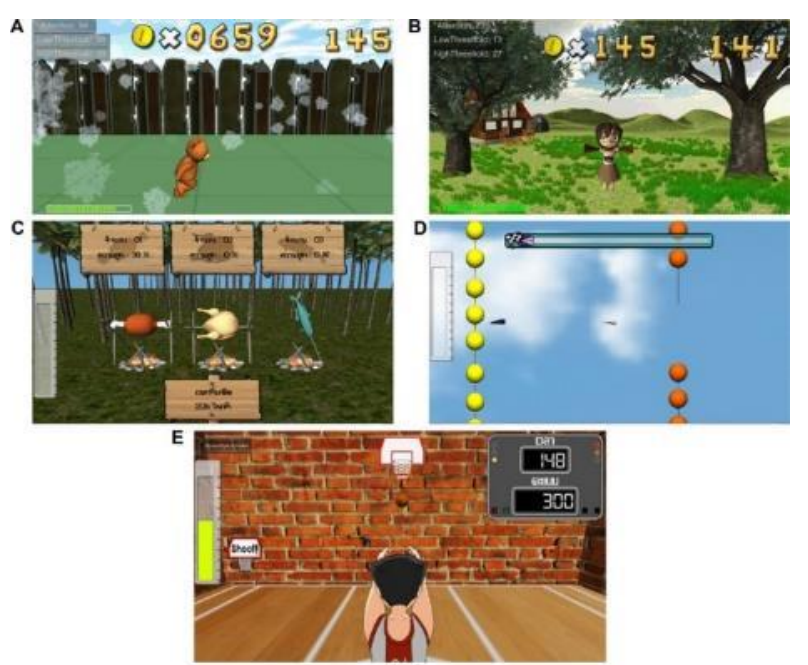

Figura 5: Jogos utilizados no treinamento neurológico: (A) Run, (B) Sun Shine Day, (C) Cast Away, (D) Paper Plane e (E) Shoot (13)

Verena E. Johann e Julia Karback (18), tentaram desenvolver e validar novas abordagem para avaliar funções executivas em crianças com tarefas baseadas em jogo. Neste trabalho, foram comparados o desempenho e a percepção pessoal dos participantes em duas versões de testes, uma em formato de jogo e outra em formato tradicional. O trabalho focou em crianças do terceiro e quarto ano (média de 9,3 anos) e coletou relatos pessoais dos participantes quanto ao interesse nos testes, concluindo que a percepção de interesse competência e motivação foi maior na versão baseada no jogo. Quanto ao desempenho na tarefa, não houve diferença entre a tradicional e a gamificada, embora a identificação com a tarefa fosse maior na versão gamificada do que na versão tradicional. O jogo utilizado apresentava uma introdução onde ao jogador era apresentada a história de um mago bondoso que precisa reunir poder para derrotar o mago malvado que dominou o reino. Depois de expostos à introdução, os jogadores precisavam realizar diversas tarefas, como, por exemplo, um teste tipo Stroop no qual são mostradas diversas figuras em que a parte de cima pode ou não ser congruente com a parte de baixo e o participante precisa nomear a figura baseando-se apenas em uma das metades, inibindo a informação da outra parte. Outro exemplo é um teste de memória de trabalho, n-Back Task, onde após apresentado a figuras como uma capa mágica, uma vassoura voadora ou uma varinha mágica, o participante precisa dizer se o objeto atual combina com o objeto mostrado n-passos antes. Ao final de cada tarefa, uma quantidade de pontos era atribuída na forma do aumento do poder mágico do protagonista, para aumentar 
o sentimento de recompensa e a imersão.

As tarefas oferecidas no jogo foram idênticas às oferecidas fora dele, e foram fornecidas pelo NeuroNation (http://www.neuronation.com), um site desenvolvido por um time de cientistas e que fornece minijogos para treinar funções especificas do cérebro. A Figura 6 mostra algumas das imagens extraídas do jogo.

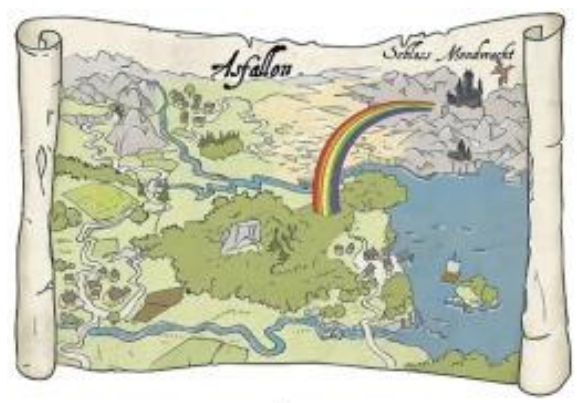

A

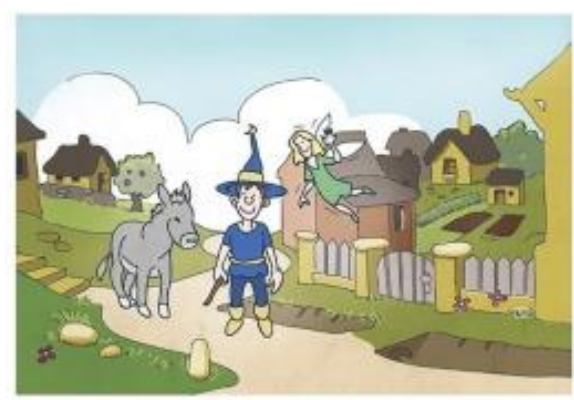

$\mathrm{C}$

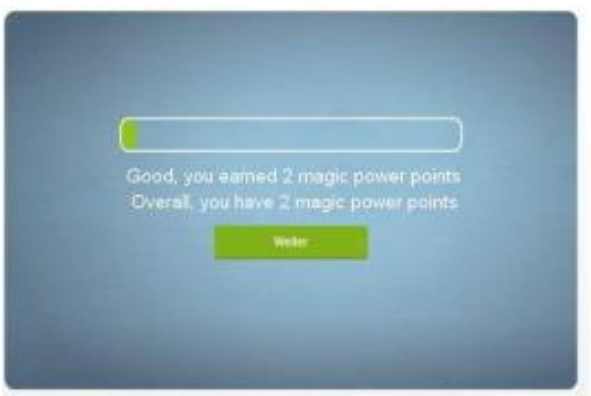

E

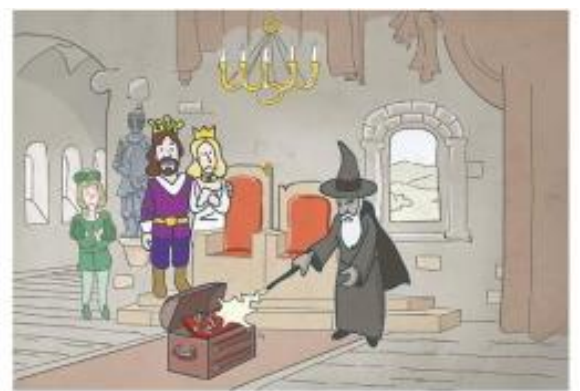

B

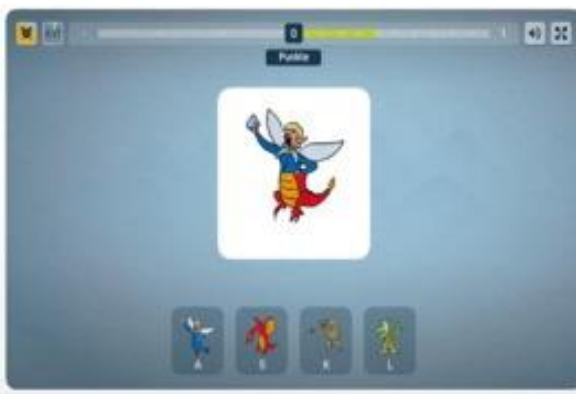

D

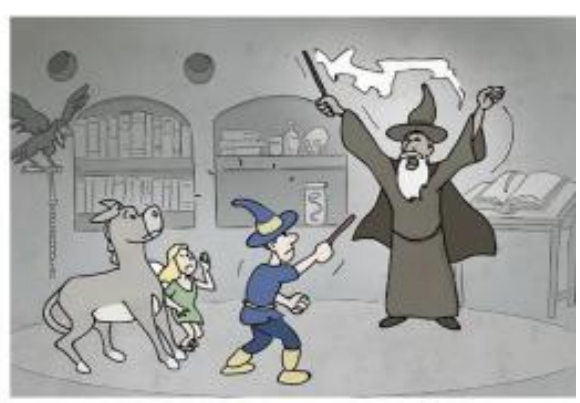

$\mathrm{F}$

Figura 6: (A) Mapa do Jogo. (B) Mago maldoso roubando o tesouro do reino. (C) Protagonista. (D) Teste Stroop. (E) Pontuação adicionada na forma de poder mágico. (F) Batalha Final. (19)

No trabalho de Tiffany Tong et al. (19), os idosos participantes do jogo deveriam acertar alvos (toupeiras) enquanto eram distraídos por borboletas e deviam evitar bater em toupeiras com chapéus em uma tarefa do tipo (go / no go).

Chicchi Giglioli IA et al. (20) avaliaram que os jogos sérios são uma nova metodologia, alternativa aos testes tradicionais ou mesmo a testes computadorizados, para avaliar funções executivas em simulações de ambientes 
reais. Além disso, este trabalho ressalta o que os jogos sérios podem fazer em termos de tecnologia e forma de interação. De fato, os jogos sérios podem ser renderizados via um ambiente não imersivo em 2D (i.e. bidimensional) ou em um ambiente imersivo de realidade virtual 3D (i.e., tridimensional). Partindo de tal premissa, foi feita uma comparação de jogo sério contextualizado com narrativa em 2D e em realidade virtual (RV). Apesar dos resultados não apontarem em definitivo para $2 \mathrm{D}$ ou $\mathrm{RV}$, ambas as tecnologias mostraram respostas com maiores tempos de latência e mais respostas corretas do que tarefas tradicionais. A Figura 7 ilustra o jogo desenvolvido para o trabalho.

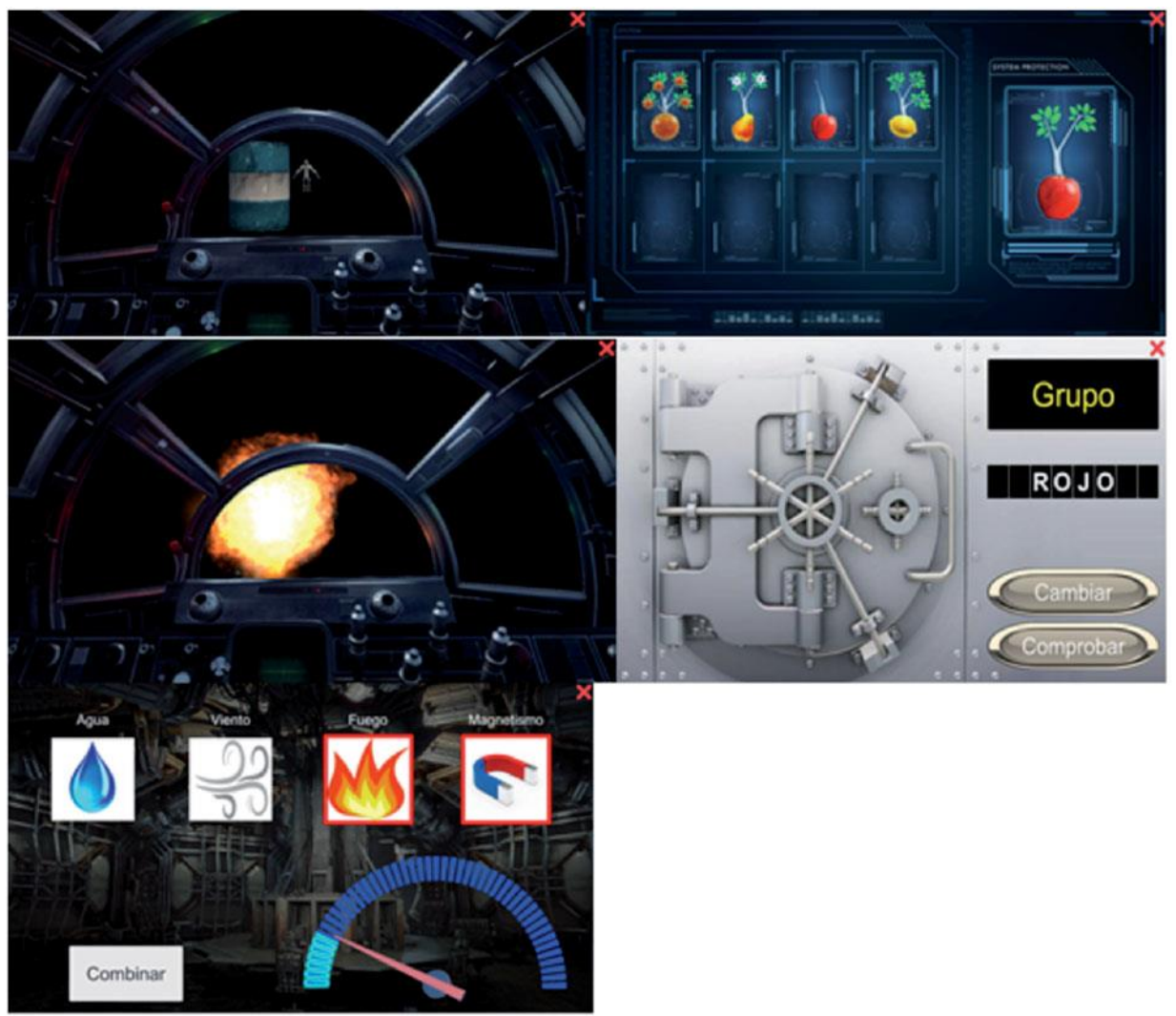

Figura 7: Game desenvolvido para testar se a imersão resulta em melhores desempenhos nos testes (12)

Embora haja uma noção bem difundida de que o convívio social é benéfico para a saúde mental do ser humano, esta correlação carece de mais evidências empíricas. O fato de a medida da felicidade de um indivíduo ser difícil de quantificar cria algumas dificuldades para se parametrizarem dados para a comparação entre estudos. Além disso, a natureza das interações sociais pode mudar em intensidade e qualidade ao longo do tempo, criando mais um dificultador em quantificar seus efeitos prolongados na saúde mental do indivíduo. Kuiper et al (21) abordam a questão de como ainda não está claro em que extensão as relações sociais estão 
associadas ao desenvolvimento de demência. Esta questão é importante para a presente dissertação, porque socialização é um dos pilares do jogo aqui proposto (Lugares Divertidos). No estudo de Kuiper et al. [op. cit.], foram comparados outros 19 estudos longitudinais de onde foram usados dados para concluir que solidão, baixa participação social e menor frequência de contato social estavam significativamente associadas à incidência de demência. A conclusão foi que uma baixa interação social está tão diretamente relacionada à incidência de demência quanto fatores mais classicamente reconhecidos, como pouca educação, inatividade física e depressão tardia.

Diversos estudos mostram que engajamento social e atividades de lazer têm um papel importante em manter o indivíduo saudável de uma forma geral (22). Pessoas com mais laços sociais tendem a viver mais (23) (24) ter um quadro geral de saúde melhor (25) (26) e ser menos susceptíveis à depressão (27). Outros estudos sugerem que o engajamento social e em atividades de lazer são benéficos para a cognição de adultos de idade mais avançada, como a redução do risco de declínio cognitivo quanto maior é o engajamento social (28) ou a relação direta entre mais atividades sociais e redes sociais maiores com melhor funcionamento executivo em indivíduos maiores de 65 anos (29).

A análise dos trabalhos relacionados mostrou grande sinergia entre a utilização de jogos e áreas da psicologia e neurociência. Muitos dos trabalhos utilizaram o auxílio de jogos para melhorar a coleta de dados ou permitir a identificação de funções executivas. Apesar de ter sido detectado um número crescente de trabalhos combinando jogos com a avaliação de funções executivas, a esmagadora maioria destes trabalhos usou jogos simples ou a implementação digital direta dos testes clássicos da psicologia e neurociência.

Dentre os trabalhos encontrados, dois se destacaram dos demais, principalmente por fugirem da mera implementação digital de testes da psicologia. O primeiro foi o de Valladares et al. (12) que mostrou-se o de maior impacto e precisão na detecção de déficit cognitivo, valendo-se de aprendizado de máquina para prever sua ocorrência. Este trabalho usou métricas consagradas na área médica e coletou variáveis que são diretamente relacionadas aos testes aplicados, tais como o número de evocações corretas ou o número de omissões em memória de curto e longo prazo. Em Lugares Divertidos, espera-se coletar muitas outras variáveis, boa parte delas 
consideradas indiretas, ou seja, relacionadas a um comportamento do jogador durante a partida, mas não diretamente relacionada a algum teste. Além disso, espera-se produzir uma métrica exclusiva para cada função executiva, embora uma abordagem menos granular, com uma detecção do tipo "comprometimento cognitivo vs condição saudável” possa também ser implementada em versões futuras. Lugares Divertidos também se destaca por permitir o psicólogo configurar o jogo e interferir no ambiente durante a simulação.

O segundo trabalho a se destacar foi o de Kraczyk (15), que utilizou um game com visual realista, excelente qualidade gráfica e atividades do dia a dia para exercitar e melhorar o desempenho dos jogadores em funções executivas. Em Lugares Divertidos, espera-se também aproveitar-se do contexto e além disso, entregar os diferenciais da configuração por parte do psicólogo e da dimensão multijogador online, que pode trazer novas possibilidade de identificação e treinamento de funções executivas. Quanto à qualidade gráfica, em Lugares Divertidos, optou-se por um visual mais lúdico, pois acredita-se que o mesmo possa tornar a experiência mais agradável.

Uma maneira de comparar a abordagem proposta nesta dissertação com a dos outros trabalhos é observar que aqui se está evitando a mera aplicação digital de testes classicamente feitos em consultórios, visto que a simples tradução da técnica tradicional para um meio digital não representa inovação. A ideia do presente trabalho é criar procedimentos e técnicas diferentes e oriundas das novas possibilidades do mundo digital.

Embora a maioria destes trabalhos tenha tido um resultado positivo, acredita-se que o uso de um jogo mais complexo, mais interativo e com atividades cotidianas, como o proposto em Lugares Divertidos, pode elevar o contexto a níveis mais intensos e adequados para cada tipo de paciente. 


\section{Psicologia Cognitiva, Neuropsicologia e Funções Executivas}

O jogo proposto nesta dissertação (Lugares Divertidos) se apoia em conceitos de psicologia para tentar avaliar as funções executivas do cérebro, com esperança de no futuro poder diagnosticar seu déficit e até mesmo ajudar na melhoria do seu desenvolvimento, mitigando eventuais efeitos do envelhecimento que se refletem no declínio cognitivo. Este capítulo se dedica a explorar estes conceitos que precisam ser compreendidos antes que se possa entender como o jogo busca atender seus objetivos.

\subsection{Cognição}

A cognição é a aquisição de conhecimento e compreensão por meio do pensamento e experiências. Os processos que ocorrem no cérebro e principais responsáveis pela cognição são: memória, atenção, linguagem, percepção, pensamento e aprendizado.

A atenção é o processo cognitivo por meio do qual podemos focar em um determinado estímulo vindo do ambiente. A memória diz respeito à capacidade do cérebro de codificar, armazenar e recuperar informações. O pensamento é responsável pela interpretação das informações recebidas e permite que o indivíduo tome decisões e resolva problemas. O Aprendizado permite a absorção de conhecimento e sua incorporação ao que o indivíduo já sabe. A linguagem responde pela capacidade de compreender e expressar pensamentos, seja de forma oral ou escrita. A percepção permite que os estímulos vindos do ambiente sejam utilizados para responder e interagir com o mundo. (7)

\subsection{Psicologia Cognitiva}

A Psicologia Cognitiva é o estudo dos processos responsáveis pela cognição e se dedica a compreender como as pessoas percebem, aprendem, se lembram e 
pensam sobre informações (7). Porque os objetos parecem mais distantes quando há neblina? Porque nos lembramos muito bem de pessoas da nossa infância, mas não muito bem de pessoas que conhecemos uma semana atrás? Porque executivos de marketing gastam tanto dinheiro de suas companhias com propagandas? Estas são algumas das questões que a psicologia cognitiva tenta responder. Para tanto baseia-se em métodos como experimentos controlados, auto relatos, observações e simulações computacionais.

\subsection{Neuropsicologia}

A neuropsicologia é um ramo da psicologia que estuda a relação entre a cognição e o cérebro, se ocupando tanto do entendimento desta relação quando saudável, como da identificação e tratamento das disfunções que podem ocorrer por algum dano cerebral ou mesmo pelo envelhecimento. (30)

A Figura 8 ilustra a anatomia do cérebro e suas regiões.

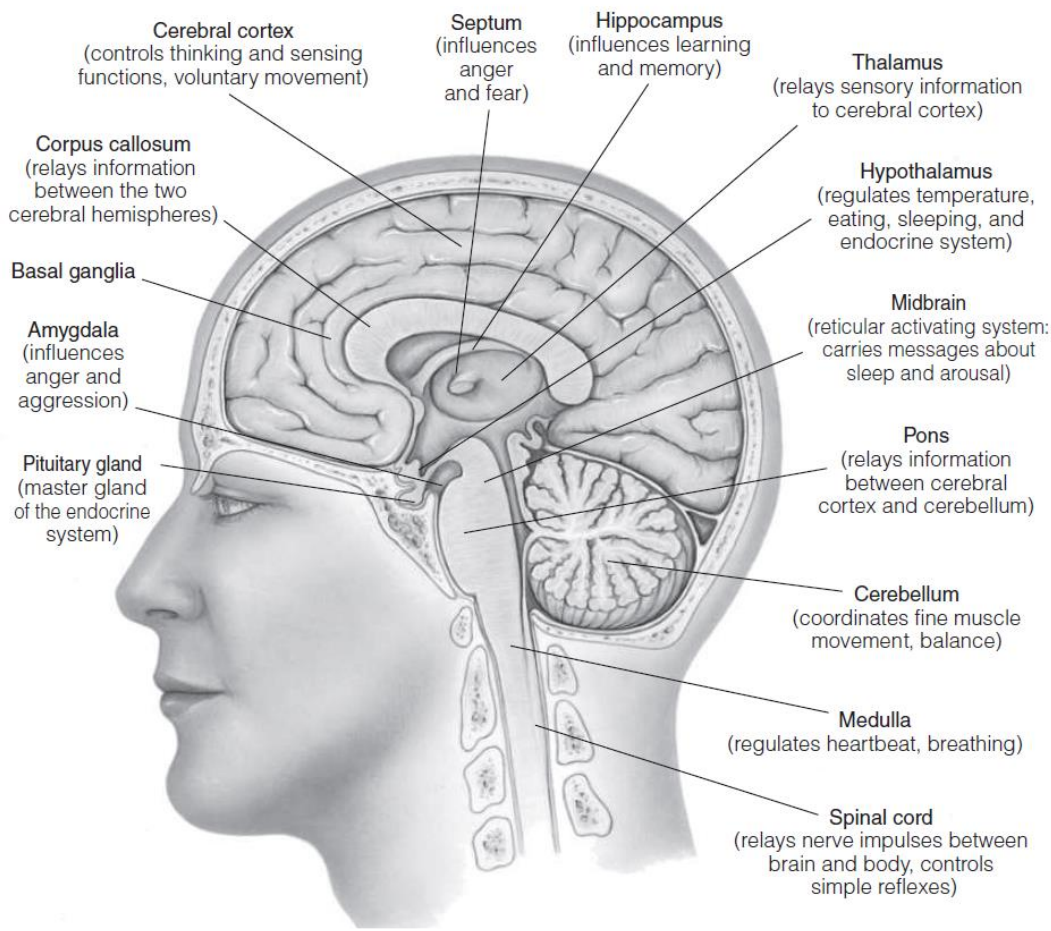

Figura 8: Regiões do cérebro e suas funções. (7) (fonte: In Search of the Human Mind, por Robert J. Sternberg)

O cérebro pode ser dividido em 3 grandes regiões: prosencéfalo, mesoencéfalo 
e rombencéfalo.

O mesoencéfalo ajuda no controle dos movimentos oculares e na coordenação, mas é mais importante em não mamíferos, pois o principal controle destas funções nos mamíferos fica por conta da região frontal do cérebro. (7)

O rombencéfalo é composto pela medula oblongata ou bulbo, que se liga com a medula espinhal e responde pelo controle da respiração, deglutição e digestão. O cerebelo controla o equilíbrio, coordenação motora e alguns aspectos relacionados com a memória procedimental para desenvolvimento de tarefas baseadas em procedimento. (7)

O prosencéfalo, fica na região frontal e é composto por: córtex cerebral, gânglios da base, sistema límbico, tálamo e hipotálamo. O sistema límbico é composto de três estruturas cerebrais interconectadas: septo, responsável pela raiva e medo; amídala, que também atua no controle do medo e das emoções e hipocampo, que tem papel crucial na memória. O tálamo tem função de traduzir informações sensoriais para o cérebro. O hipotálamo também tem função regulatória das emoções e de instintos de sobrevivência. Já o córtex cerebral é a maior estrutura do cérebro e ocupa toda a camada externa dele. Seu papel é primordial nas funções cognitivas e no processamento de alto nível, sendo essencial aos processos cognitivos mencionados neste capítulo (memória, atenção, linguagem, percepção, pensamento e aprendizado). (7)

\subsection{Declínio Cognitivo com a Idade Avançada}

As funções cognitivas podem ser afetadas não apenas por dano cerebral decorrente de acidentes ou impactos, mas com alguma frequência pelo envelhecimento que também muda as estruturas cerebrais (4), modificando a cognição. Entretanto, alguns adultos de idade mais avançada experimentam declínio pequeno nas funções cognitivas, já outros sofrem perdas tão grandes que podem levar à demência severa, como nos casos de doenças neurodegenerativas. Mesmo em indivíduos que "envelhecem bem", a perda em relação ao seu desempenho quando jovens é perceptível e por vezes, incômoda. Algumas funções como memória de trabalho e atenção são as mais suscetíveis à perda de eficiência, 
enquanto percepção visual e conhecimento por exemplo normalmente se mantém bem preservadas. (31)

Mudanças estruturais, fisiológicas e metabólicas (32) (33) são as principais responsáveis pelo declínio cognitivo observado em grande parte dos idosos. Estas mudanças são mais acentuadas em idosos com doenças neurodegenerativas, como o mal de Alzheimer. A Figura 9 ilustra a diferença entre um cérebro saudável e um com Alzheimer.

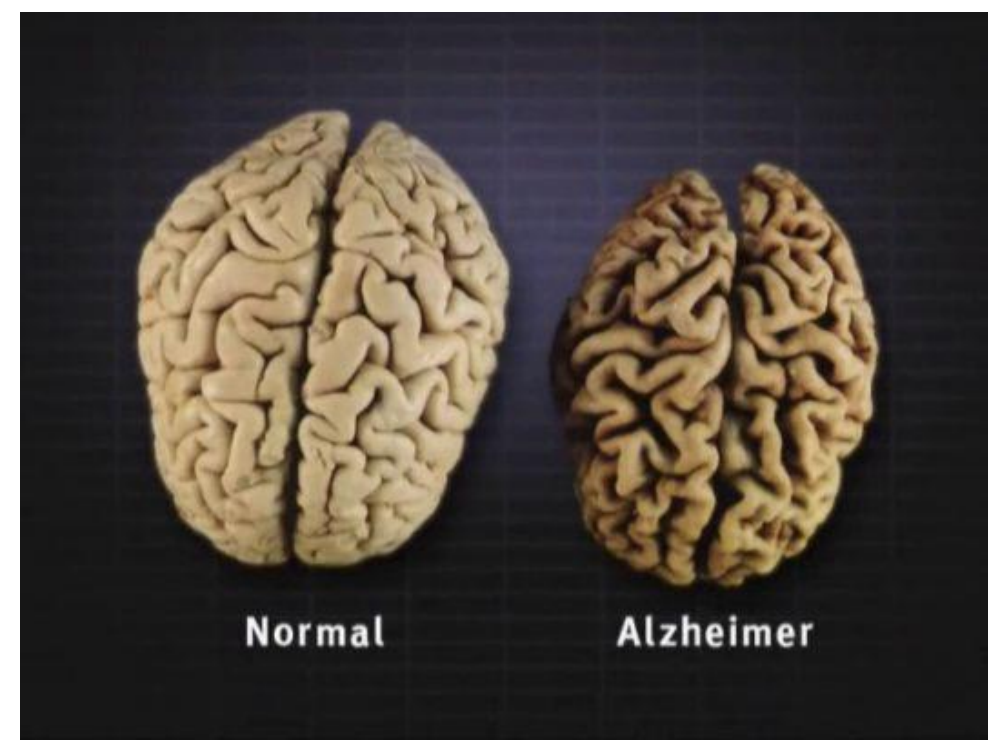

Figura 9: Cérebro Normal X Cérebro com Alzheimer (32)

A neuropsicologia provê meios para identificar, diagnosticar e em alguns casos, tratar a perda de capacidade cognitiva. Um dos grandes objetivos de Lugares divertidos é servir de ferramenta para auxiliar nestas tarefas.

\subsection{Funções Executivas}

Embora não haja um consenso quanto à conceituação das FE, elas geralmente são definidas como um conjunto de habilidades ou processos do cérebro, essenciais ao controle voluntário para realizar um objetivo especifico (8) (5) (34). Estas habilidades permitem que o indivíduo pense antes de agir, controle suas ações, planeje e execute uma sequência de passos para realizar uma tarefa e mantenha a atenção e o foco. São essenciais para a realização de tarefas do dia a dia (10) e o déficit delas pode tornar difícil se concentrar, seguir instruções ou até mesmo controlar as emoções. A Tabela 1 ilustra situações onde ficaram claras evidências 
de que as funções executivas afetam a vida das pessoas, bem como as referências dos estudos que comprovaram tais influências.

As funções executivas podem ser divididas em Funções Frias e Funções Quentes (6). As frias, correspondem ao funcionamento do lobo pré-frontal do córtex cerebral e correspondem aos componentes cognitivos, estando envolvidas nos processos controlados e nas etapas necessárias para execução de um comportamento novo ou dirigido a uma meta específica. Elas englobam o planejamento, iniciativa, monitorização, memória de trabalho e atenção seletiva dividida e alternada, além da fluência verbal. Já as funções quentes respondem pela regulação emocional do comportamento e o controle inibitório, controle da impulsividade e da reatividade emocional. A empatia social, que envolve entender os comportamentos e emoções do outro também faz parte das funções executivas quentes. (6)

Entre 5 e 13 anos, há um salto no desenvolvimento destas habilidades, que em geral apresentam um declínio perceptível acima de 60 anos.

As funções executivas são responsáveis pela iniciativa e pelo controle de uma atividade nova. Após a repetição, as funções executivas são necessárias apenas para iniciar a atividade. No processo de envelhecimento, com seu declínio, os idosos tentem a realizar mais processos automáticos do que controlados, preferindo se ater a uma rotina superaprendida ao longo dos anos, por isso são tão avessos a mudanças. (6)

As funções executivas serão abordadas em detalhe nas próximas seções.

Tabela 1: Importância das Funções Executivas. (5)

\begin{tabular}{|c|c|c|}
\hline Aspecto da Vida & Como as FE são Relevantes & Referências \\
\hline \multirow{6}{*}{ Saúde Mental } & Vícios & Baler \& Volkow 2006 \\
\hline & $\begin{array}{l}\text { Déficit de atenção e } \\
\text { hiperatividade }\end{array}$ & $\begin{array}{l}\text { Diamond 2005, Lui \& } \\
\text { Tannock } 2007\end{array}$ \\
\hline & Transtornos de Conduta & Fairchild et al. 2009 \\
\hline & Depressão & $\begin{array}{l}\text { Taylor-Tavcares et al. } \\
2007\end{array}$ \\
\hline & $\begin{array}{l}\text { Transtorno } \\
\text { Compulsivo }\end{array}$ & Penadés et al. 2007 \\
\hline & Esquizofrenia & Barch 2005 \\
\hline
\end{tabular}




\begin{tabular}{|c|c|c|}
\hline Saúde Física & $\begin{array}{l}\text { Baixa capacidade nas FE está } \\
\text { associada com Obesidade, } \\
\text { compulsão alimentar, abuso } \\
\text { de substâncias, baixa } \\
\text { aceitação aos tratamentos }\end{array}$ & $\begin{array}{l}\text { Crescioni et al. 2011, } \\
\text { Miller et al. 2011, } \\
\text { Riggs et al. } 2010\end{array}$ \\
\hline Qualidade de Vida & $\begin{array}{l}\text { Pessoas com FE mais bem } \\
\text { desenvolvidas experimentam } \\
\text { uma melhor qualidade de } \\
\text { vida. }\end{array}$ & $\begin{array}{l}\text { Brown \& Landgraf } \\
\text { 2010, Davis et al. } 2010\end{array}$ \\
\hline Prontidão Escolar & $\begin{array}{l}\text { FE são mais importantes } \\
\text { para prontidão escolar do } \\
\text { que o QI, noções de } \\
\text { alfabetização ou matemática }\end{array}$ & $\begin{array}{l}\text { Blair \& Razza 2007, } \\
\text { Morrison et al. } 2010\end{array}$ \\
\hline Sucesso escolar & $\begin{array}{l}\text { As funções executivas } \\
\text { predizem ambos a } \\
\text { competência na leitura e na } \\
\text { matemática ao longo dos } \\
\text { anos escolares }\end{array}$ & $\begin{array}{l}\text { Borella et al. 2010, } \\
\text { Duncan et al. 2007, } \\
\text { Gathercole et al. } \\
2004\end{array}$ \\
\hline Sucesso no Emprego & $\begin{array}{l}\text { Funções executivas pouco } \\
\text { desenvolvidas apontam para } \\
\text { baixa produtividade e } \\
\text { dificuldade em encontrar e } \\
\text { manter um emprego }\end{array}$ & Bailey 2007 \\
\hline Harmonia Matrimonial & $\begin{array}{l}\text { Um companheiro com } \\
\text { funções executivas } \\
\text { deficientes pode ser mais } \\
\text { difícil de se conviver, menos } \\
\text { confiável e mais propenso a } \\
\text { agir por impulso }\end{array}$ & Eakin et al. 2004 \\
\hline Segurança Publica & 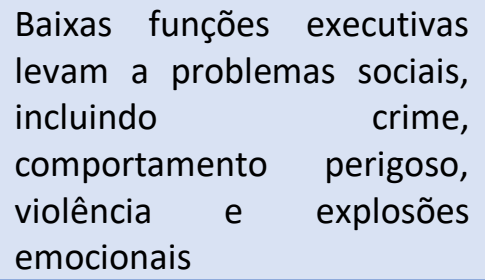 & $\begin{array}{l}\text { Broidy et al. 2003, } \\
\text { Denson et al. } 2011\end{array}$ \\
\hline
\end{tabular}

\subsubsection{Memória de Trabalho}

A memória de trabalho é um estoque transitório de informações na memória de curto prazo, essencial enquanto estamos realizando uma determinada tarefa e é importante para qualquer tarefa que se desenrole com o tempo. (5) Exemplos de seu uso são ler (8), escrever, fazer contas de cabeça (35), reordenar itens mentalmente, digitar uma senha de banco depois de tê-la visto no papel e dirigir um carro desviando dos buracos em uma estrada de terra. A memória de trabalho engloba períodos curtos onde a informação precisa ser recebida ou mantida. 
Períodos mais longos, superiores a 1 minuto já não contemplam esta função executiva. A memória de trabalho está associada a um melhor rendimento escolar, como foi mostrado na Tabela 1.

Alguns dos testes psicológicos da memória de trabalho são (36) :

- Trigramas de Consoantes - neste teste o indivíduo ouve uma silaba (sem sentido) de 3 letras, seguidas de um número. Em seguida, ele deve contar regressivamente a partir do número e, em dado momento, ao receber um sinal, deve informar as 3 letras da sílaba sem sentido. (37)

- Blocos de Corsi - Em um tablado preto com nove cubos idênticos distribuídos de maneira que o probando é orientado a repetir uma sequência de toques realizados pelo profissional, primeiramente de forma direta e, em um segundo momento, em ordem inversa. (36)

- Digit Span - usado para medir a capacidade de armazenamento da memória de trabalho. Neste teste o paciente vê ou escuta uma sequência de dígitos e deve se recordar da sequência corretamente. (38)

\subsubsection{Flexibilidade Cognitiva}

A flexibilidade cognitiva é a habilidade de alternar entre ações e permite se adaptar a mudanças em um ambiente. Esta função executiva é importante para se realizar tarefas múltiplas (5) (39). Ela inclui a habilidade de abandonar informações irrelevantes em uma tarefa anterior e focar em informações relevantes para a tarefa que se segue (40). A flexibilidade cognitiva se desenvolve rapidamente na préescola e continua a evoluir até a adolescência. Estudos apontaram para a relação direta entre flexibilidade cognitiva e sucesso acadêmico em termos de aptidão para leitura e aptidão matemática em crianças (41) (42).

Exemplos de tarefas que usam esta função executiva são: ter que mudar a rota que se toma todo dia para o trabalho por causa de uma obra, começar a separar cartas de baralho em duas pilhas, uma com pares e outra com impares e, no meio da tarefa, mudar para um critério de cores. Um exemplo de teste muito utilizado é o Dimensional Change Card Sorting, onde crianças primeiro devem separar as cartas de acordo com o formato e subsequentemente baseando-se nas cores (Figura 
10).

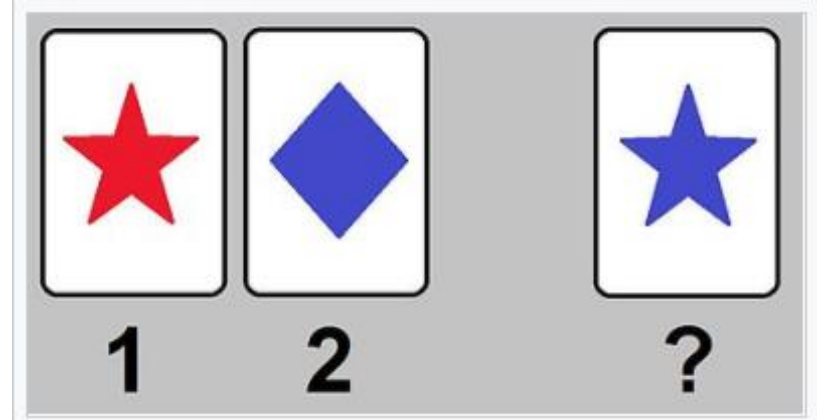

Figura 10: Dimensional Change Card Sorting (fonte:

https://en.wikipedia.org/wiki/Cognitive_flexibility\#/media/File:Dimensional_Change

Card_Sorting_Task.jpg)

Alguns dos testes psicológicos usados para avaliar a flexibilidade cognitiva são:

- Teste de Seleção de Cartas de Wisconsin (WCST) - Nesse teste, o examinador apresenta ao probando uma série de cartas (uma de cada vez), as quais devem ser agrupadas de acordo com uma entre quatro cartas-alvo.

Para isso, o sujeito deverá escolher um determinado critério de categorização. Este critério não é mencionado para o sujeito, cabendo a ele descobrir ao longo de suas escolhas. A cada escolha o examinador diz ao probando se o critério adotado está correto ou não (36).

- Teste das Trilhas - O Teste de Trilhas (Trail Making Test) é composto pelas partes A e B e apresenta estímulos não verbais, como números em ordem ascendente e letras em ordem alfabética a serem ligados com um lápis no papel, pelo paciente (36).

\subsubsection{Autocontrole Emocional}

Esta função diz respeito a capacidade de gerenciar e controlar as emoções durante uma atividade ou para atingir um objetivo. Também inclui a capacidade de se manter calmo ante um imprevisto ou contratempo. Pessoas com esta função menos desenvolvida podem experimentar mudanças repentinas de humor e sentirse derrotadas ante um empecilho. (5) (6) 


\subsubsection{Atenção Seletiva}

Esta função executiva, engloba a habilidade de focar a atenção em uma atividade, dispensando estímulos de distração e outras atividades. (6) Alguns dos testes que podem ser aplicados para sua avaliação são:

- CPT-II (Tarefa de Performance Contínua) - Consiste na apresentação de uma série de letras apresentadas rapidamente, uma de cada vez, em intervalos relativamente curtos e nos quais o sujeito deve pressionar um botão cada vez que aparece uma letra. No entanto, essa regra só valerá se a letra não for X. Caso apareça a letra $\mathrm{X}$, o sujeito deverá inibir a resposta de apertar a barra de espaço do computador.

- Teste das Trilhas

\subsubsection{Planejamento}

Esta função responde pela capacidade de planejar e organizar uma tarefa de forma organizada e sequencial. Dito de outra forma, pode-se pensar nesta habilidade com a capacidade de mentalmente antecipar a melhor maneira de realizar uma tarefa. (6) O planejamento permite que se escolha o melhor curso de ação para atingir um objetivo. Diversas tarefas do dia a dia dependem desta função executiva, como por exemplo, cozinhar, arrumar as malas e fazer compras. O déficit desta função executiva se reflete em pessoas distraídas com dificuldade de executar tarefas simultâneas, e incapacidade de antever as consequências dos seus atos.

Alguns dos testes psicológicos para avaliar a capacidade de planejamento são:

- Torre de Londres - Requer que o testando mova três esferas de cores diferentes (vermelha, azul e verde), uma de cada vez, a partir de uma "posição de partida", tentando colocá-las de acordo com "posições-alvo". Ao todo, são 12 problemas, resolvidos um de cada vez, em ordem crescente de dificuldade (36).

- Torre de Hanoi - Consiste na movimentação de discos de tamanhos diferentes, tendo por objetivo mover uma pilha deles, de um pino A para um pino $\mathrm{B}$, usando um pino auxiliar $\mathrm{C}$, sem que nunca um disco maior fique 
sobre um disco menor.

- Labirintos - O teste dos Labirintos, proposto por Porteus, em 1965, consiste na solução de diversos labirintos com níveis diferentes de dificuldade. Para solucionar cada labirinto, o participante não pode cruzar as linhas e nem refazer caminhos ao encontrar partes sem saída. Ao violar alguma das regras, o participante deve tentar resolver o labirinto novamente com um valor de pontuação reduzido (43).

\subsubsection{Monitoração}

Capacidade de auto monitorar os passos de uma tarefa para que esta seja concluída com êxito. Esta habilidade está relacionada à capacidade de avaliar se os passos tomados para a conclusão de uma tarefa são os corretos e à capacidade de detectar que alguma etapa não foi tomada corretamente (6). Esta função executiva é usada, por exemplo, ao seguir-se uma receita culinária, pois o indivíduo precisa, constantemente avaliar se a etapa sendo realizada está de acordo com as instruções da receita.

A lista de funções executivas discutidas aqui não é exaustiva, visto que há mais de uma teoria quanto a sua conceituação, mas representa funções executivas amplamente aceitas pela maioria das teorias e as mais comumente abordadas em artigos da Academia. Em paralelo, foi avaliado que estas mesmas funções seriam passíveis de serem acessadas durante uma partida de Lugares Divertidos, na sua primeira versão. Em versões futuras do jogo, novas dimensões das funções executivas podem ser adicionadas. 


\section{Conceitos, Estrutura e Uso do Jogo Proposto}

O jogo proposto nesta dissertação, Lugares Divertidos (Funny Places), tem como tema viajar com um grupo de amigos até uma nova cidade (no país ou no exterior), onde cada pessoa fica em um hotel diferente. A missão é conseguir comprar 3 itens para fazer uma festa. Para tanto, algumas ações tornam-se necessárias, tais como andar pela cidade, fazer compras em lojas e interagir com as pessoas. As missões e os sistemas implementados no jogo têm o objetivo inicial de avaliar as funções executivas. Diversas medidas são feitas ao longo do jogo, como por exemplo o total de distância percorrida, a forma como os itens foram coletados e a quantidade de vezes que algumas mecânicas de jogo foram disparadas ou botões da interface acionados. Tudo isso para gerar um registro de tudo que foi feito pelo jogador e permitir a avaliação por um psicólogo ou mesmo uma avaliação automatizada por meio de algoritmos implementados para tal. Os grandes diferenciais almejados para serem entregues em Lugares Divertidos são:

- Contexto: as funções executivas são acessadas naturalmente com atividades do jogo que têm relação com o dia a dia de um indivíduo.

- Interação Social: reconhecidamente, como já mencionado, a interação social é benéfica à saúde mental. Para tanto, Lugares Divertidos foi criado para ser um jogo multijogador online.

Além destes dois pilares, Lugares Divertidos se apresenta como um experimento configurável, no qual o psicólogo age como controlador do jogo, podendo configurar a experiência dos jogadores selecionando diversas opções, ou usando opções pré-determinadas.

Estes diferenciais e os aspectos do jogo são abordados mais detalhadamente ao longo deste capítulo.

\subsection{Bem-Vindo a Lugares Divertidos}

O ambiente de Lugares Divertidos é uma cidade colorida e aprazível de se conhecer. O local a ser explorado pelos jogadores é um bairro povoado principalmente por casas, algumas lojas de conveniência, um posto de gasolina, e 3 
hotéis pequenos localizados nos únicos prédios do mapa. Os hotéis possuem propositalmente uma arquitetura que destoa um pouco do resto da cidade, de modo a facilitar para o jogador o reconhecimento deles. Além disso, a cidade é rodeada por montanhas e árvores, há um shopping center e ruas arborizadas. A Figura 11 mostra uma vista aérea da cidade e a Figura 12 mostra o interior de uma das casas. A modelagem da cidade usa pacotes e modelos 3D disponíveis na Unity Asset Store (https://assetstore.unity.com/), com baixo número de polígonos (ver seção 5).

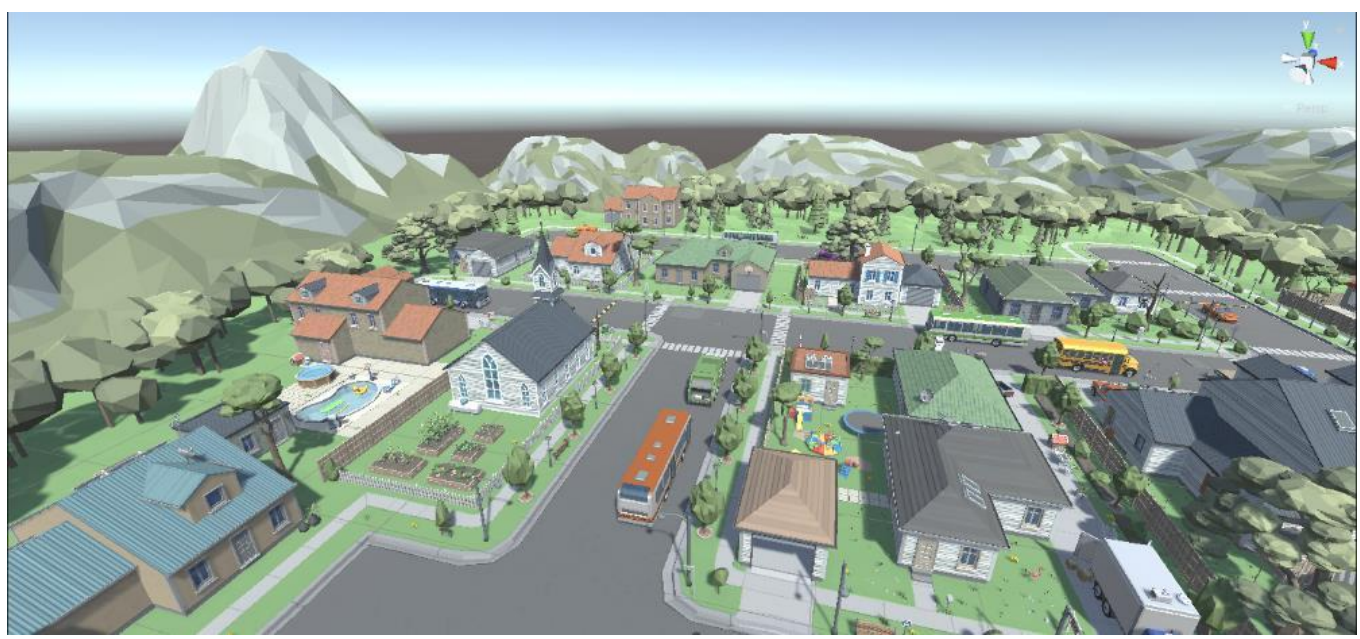

Figura 11: Vista aérea da cidade

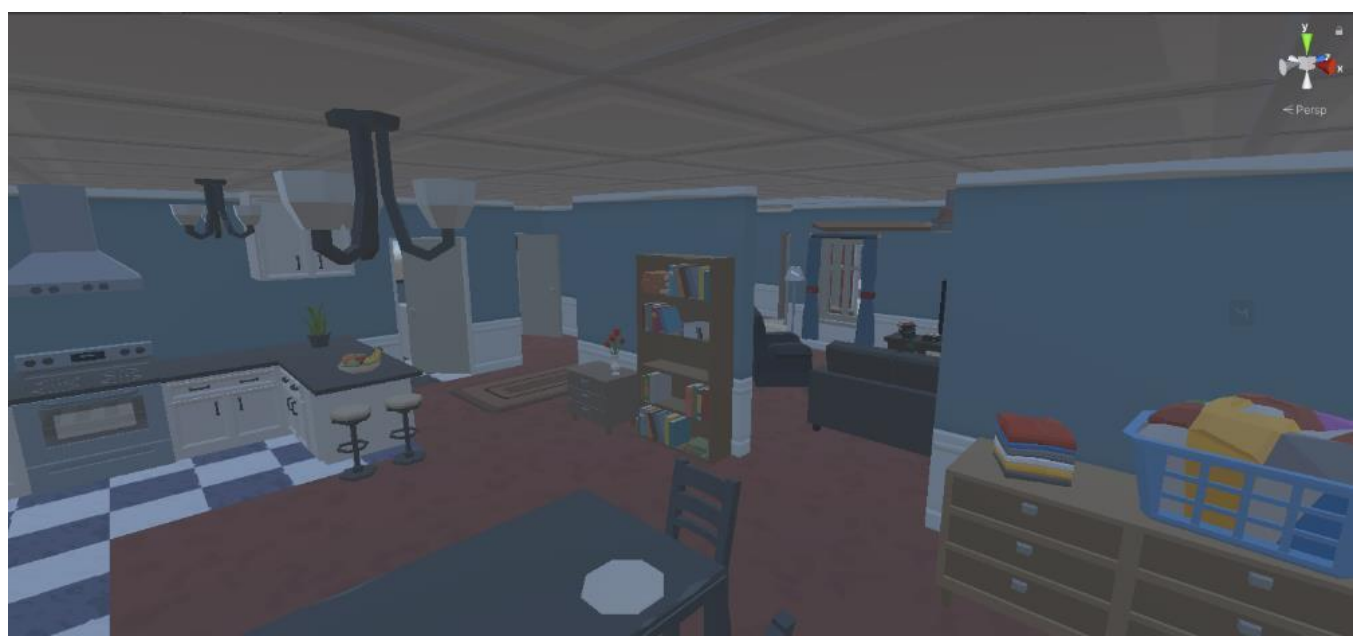

Figura 12: Interior de uma das casas visitáveis

Como as Figura 11 e Figura 12 mostram, o ambiente apresentado para os jogadores é leve e agradável de se andar. A visão do jogo é tal que a câmera fica em uma posição equivalente à cabeça do jogador, o que na terminologia de jogos é conhecido por visão em primeira pessoa (Figura 13). Este tipo de interação com o jogo visa ajudar na imersão e, em parte, transmitir um pouco da dificuldade que é navegar em uma cidade desconhecida, sem a facilidade de se erguer magicamente 
ou tecnologicamente para ver tudo de cima. Trata-se, aqui, de simular um passeio por uma cidade de maneira similar ao mundo real.

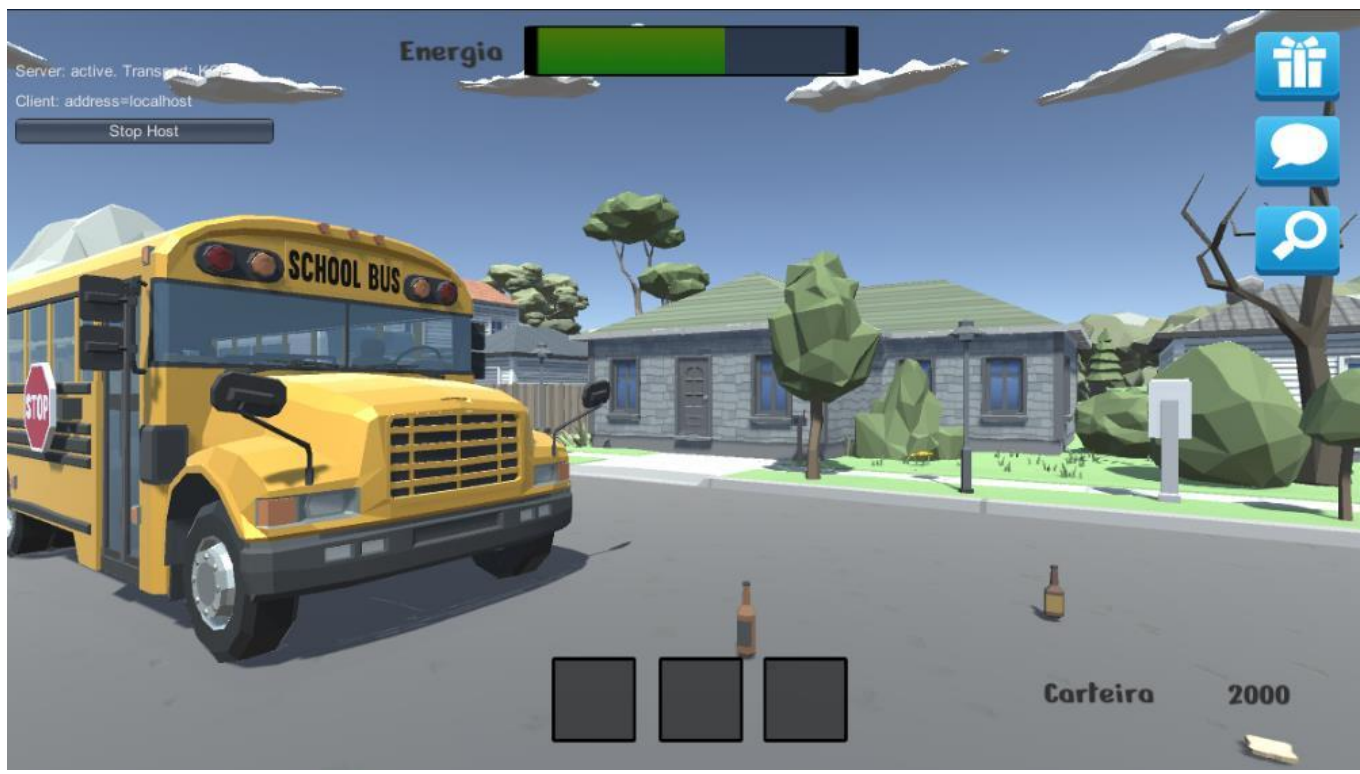

Figura 13: Visão em primeira pessoa

\subsection{Conceito do Psicólogo como Controlador}

Lugares Divertidos tem a proposta de ser um jogo configurável por um controlador. Inicialmente espera-se que esta figura seja assumida por um psicólogo. A proposta é servir como ferramenta para ajudar na identificação de funções executivas, especialmente em idosos. O psicólogo inicia o jogo no modo servidor e tem acesso a uma tela que permite que ele faça diversas configurações iniciais, como, por exemplo, o tipo de item que cada jogador terá que buscar. Esses itens, por sua posição, influem no grau de dificuldade do jogo, pois podem estar bem perto de onde o jogador inicia o jogo, ou do outro lado da cidade. Além disso, alguns itens são considerados mais difíceis do que outros, como, por exemplo, o bolo de aniversário, que requer a compra em duas etapas: o bolo em um local e as velas em outro. Ou ainda o sorvete, que precisa ser comprado por último e logo em seguida levado até o hotel do jogador, pois ele derrete em alguns minutos. Estes itens são marcados como fáceis médios ou difíceis. Além disso, a distância total é um indicador direto da dificuldade que um jogador terá para reunir os itens.

Os parâmetros da partida devem ser selecionados pelo psicólogo antes do início do jogo (Figura 14), podendo ele ainda: salvar suas configurações para repetir o 
experimento no futuro, carregar configurações usadas anteriormente ou selecionar entre um grupo de configurações predefinidas (3 fáceis 3 intermediárias e 3 difíceis). Estas configurações são independentes para cada jogador e, sendo assim, é possível ter jogadores com níveis de habilidade diferentes engajando-se no jogo com dificuldades apropriadas a cada um deles.

Outras opções do controlador do jogo são habilitar um tutorial de reconhecimento e um tutorial de movimentação. O primeiro serve para que os jogadores aprendam a diferenciar um outro jogador de um personagem controlado pelo computador, habilidade que será importante para que sejam aproveitadas as funcionalidades multijogador do game. O segundo, serve para que os jogadores possam se mover livremente pela cidade, sem restrição de tempo e sem missão nenhuma. Os tutoriais acabam quando todos os jogadores clicarem em um botão na interface que sinaliza estarem prontos, ou quando o controlador decidir encerrá-los.

Ainda dentro das possibilidades do controlador, há a opção de enviar dicas aos jogadores para auxiliar na busca pelos itens, ou até mesmo para distraí-los (Figura 15). A visão do psicólogo é aérea (Figura 16) e lhe é franqueado um controle que permite sobrevoar a cidade acompanhando as atividades dos jogadores.

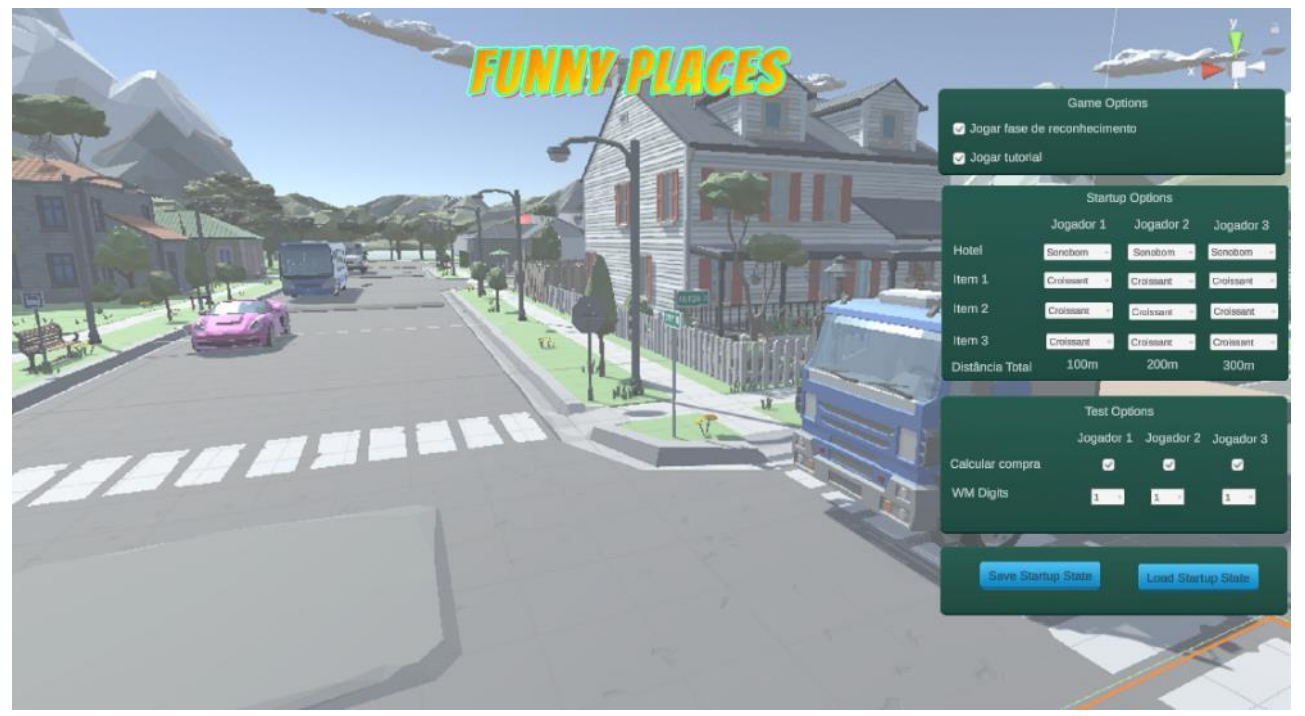

Figura 14: Configurações iniciais do psicólogo ou controlador do jogo 


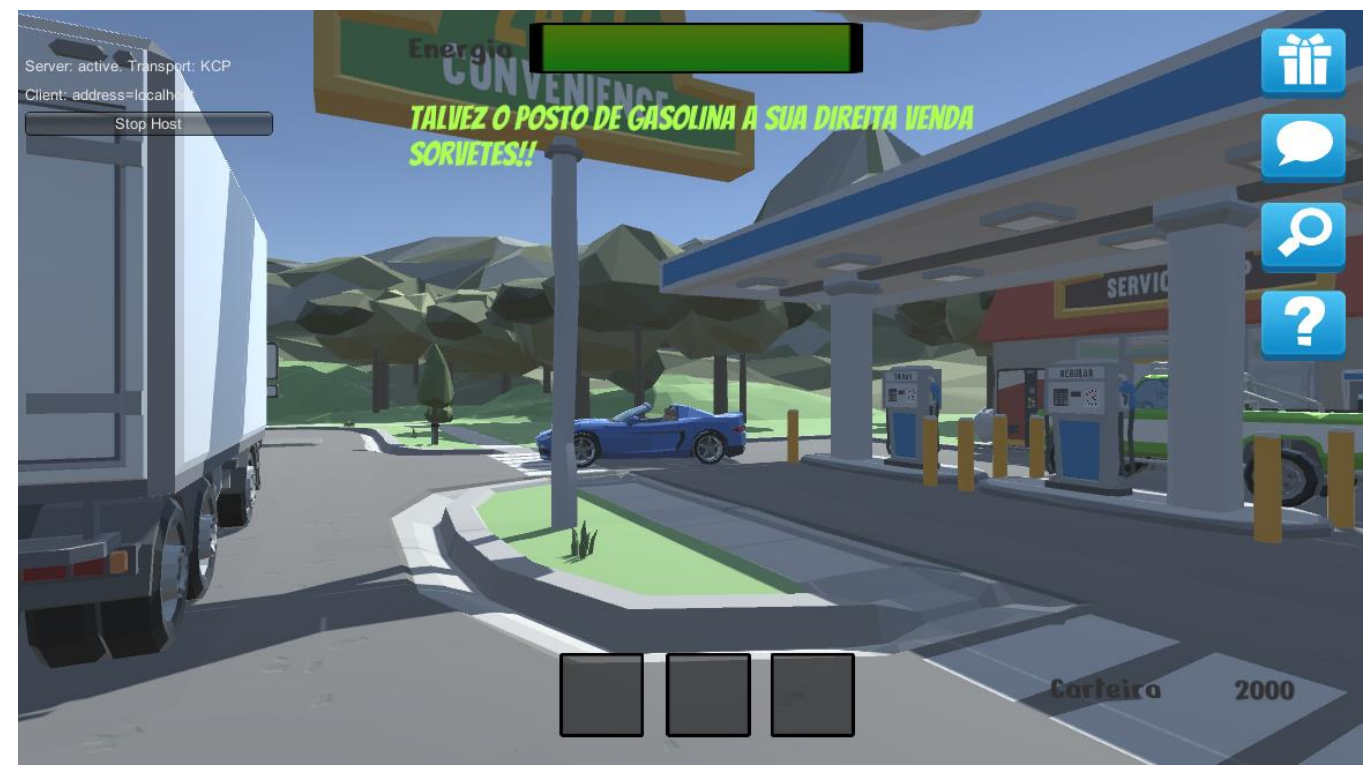

Figura 15: Mensagem do psicólogo ao jogador

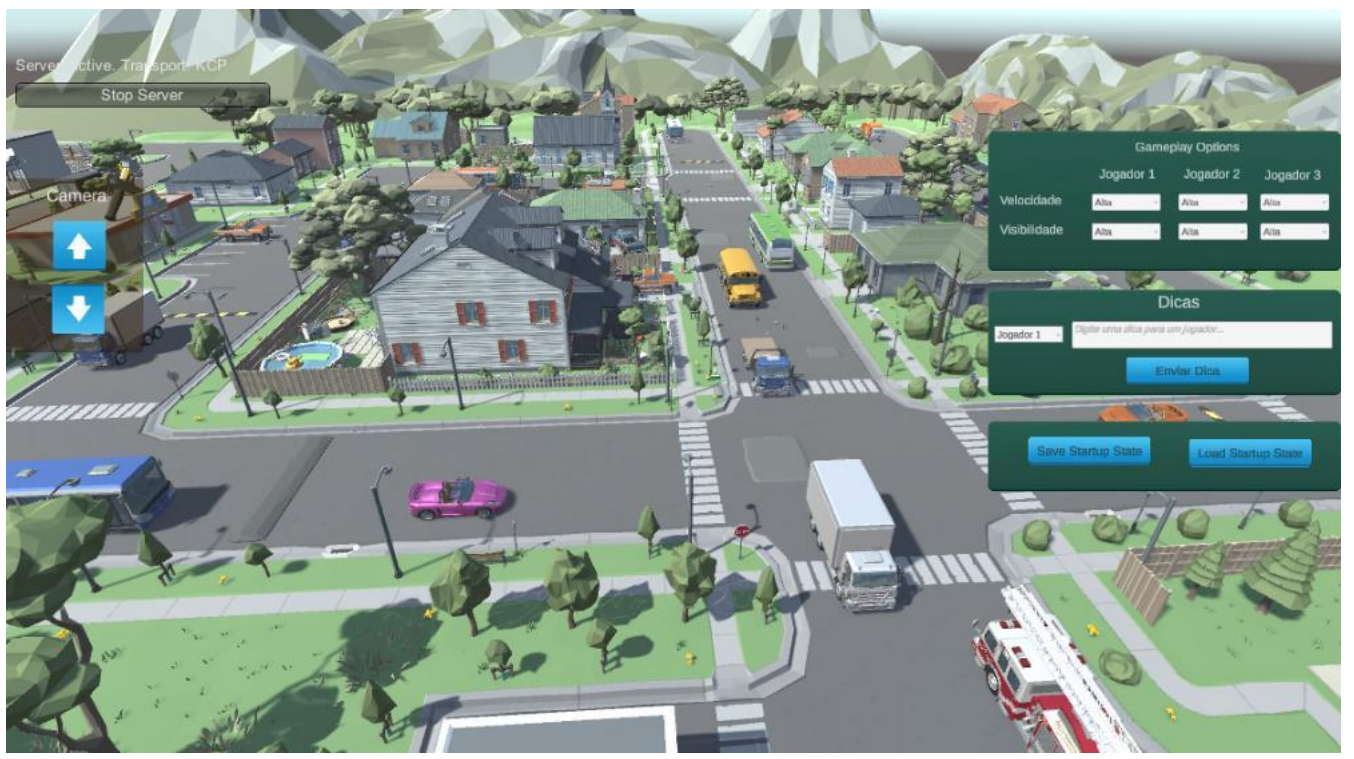

Figura 16: Visão aérea do psicólogo ou controlador durante uma partida

\subsection{Multijogador Online}

Uma das propostas de lugares divertidos é ser um jogo multijogador online. Como já foi dito, há diversas evidências que comprovam o efeito benéfico da interação social na saúde do indivíduo. A implementação do jogo usando este modelo tem a intenção de, em um primeiro momento, permitir que se trace um paralelo entre a disposição para a interação social com o desempenho do jogador no que tange as funções executivas. Em versões futuras de Lugares Divertidos, espera-se que a dinâmica e as situações envolvidas neste tipo de interação possam contribuir 
positivamente para a saúde dos jogadores.

Apesar do aspecto multijogador, não foram implementadas missões ou mecânicas de jogo que tornem a interação obrigatória. No entanto, há um reforço positivo, na forma de recuperação de energia do personagem, aumento da velocidade de movimento após uma interação ou aumento de créditos ao receber um cupom de outro jogador.

A predisposição do jogador para a interação social é medida por algumas variáveis coletadas durante a partida, tais como a quantidade de acionamentos do botão de interação e do botão que indica a direção do jogador mais próximo.

\subsection{Personagens}

Antes do início do jogo, em uma tela inicial, onde os jogadores esperam que o jogo comece, cada jogador tem a oportunidade de escolher seu avatar e visualizar os avatares escolhidos pelos outros jogadores (Figura 17). Os personagens representam pessoas comuns vestidas casualmente. Todos os personagens controlados pelo computador ${ }^{3}$ são de um grupo diferente de modelos, com indumentária que não se confunde com aquelas disponíveis para os personagens dos jogadores. Esta diferenciação visa facilitar o reconhecimento de outros jogadores por parte de um jogador, para que as mecânicas que focam no aspecto online do jogo sejam acessadas corretamente. A Figura 18 e a Figura 19 ilustram os grupos de personagens disponíveis NPCs e para os jogadores.

\footnotetext{
${ }^{3} \mathrm{Na}$ terminologia de jogos, estes personagens são denominados NPCs (Non-Player Characters)
} 


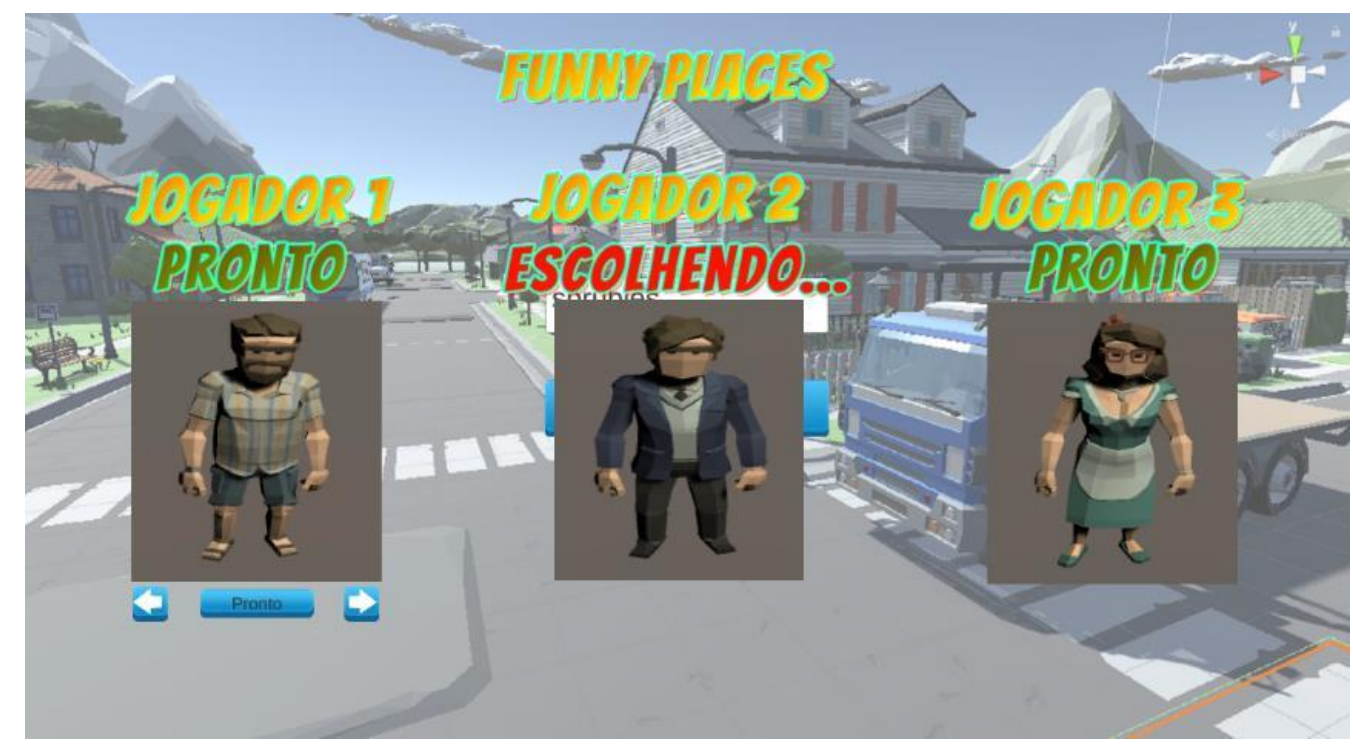

Figura 17: Tela de seleção de personagem.

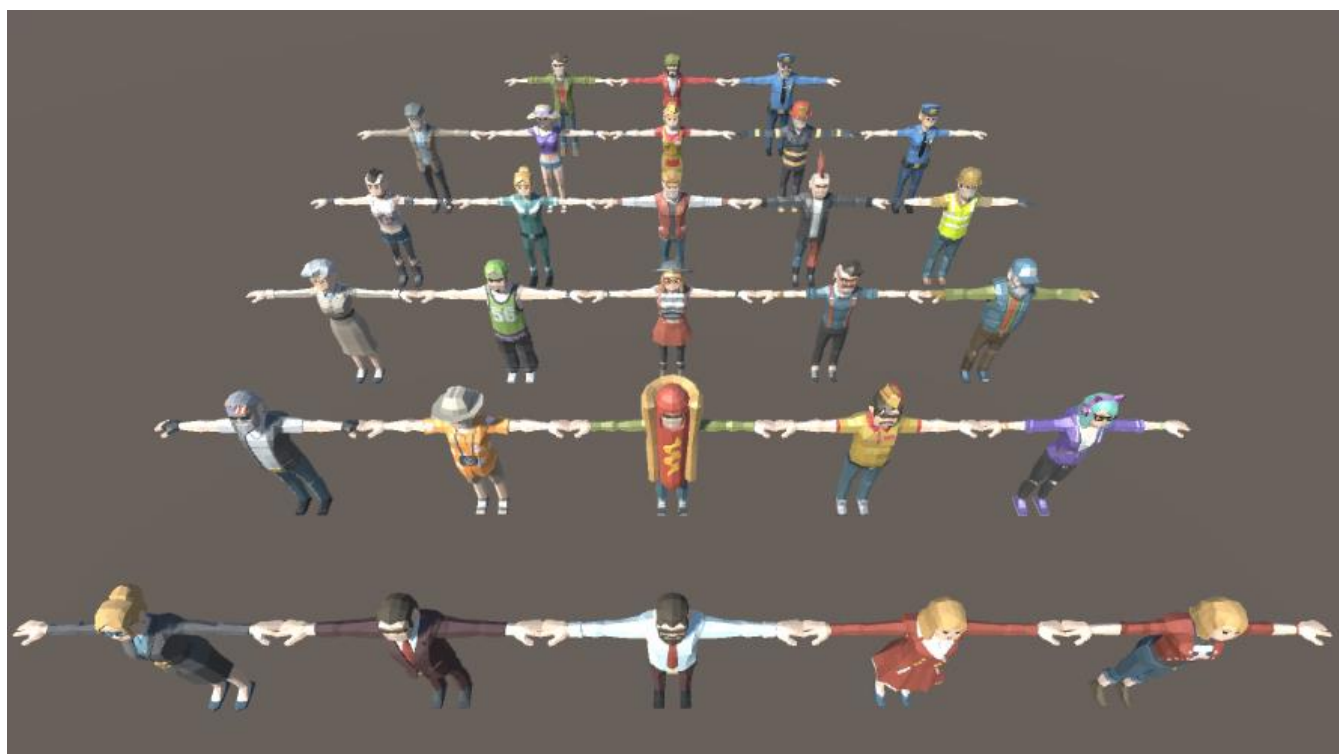

Figura 18: Personagens controlados pelo computador (NPCs - Non-Player Characters) 


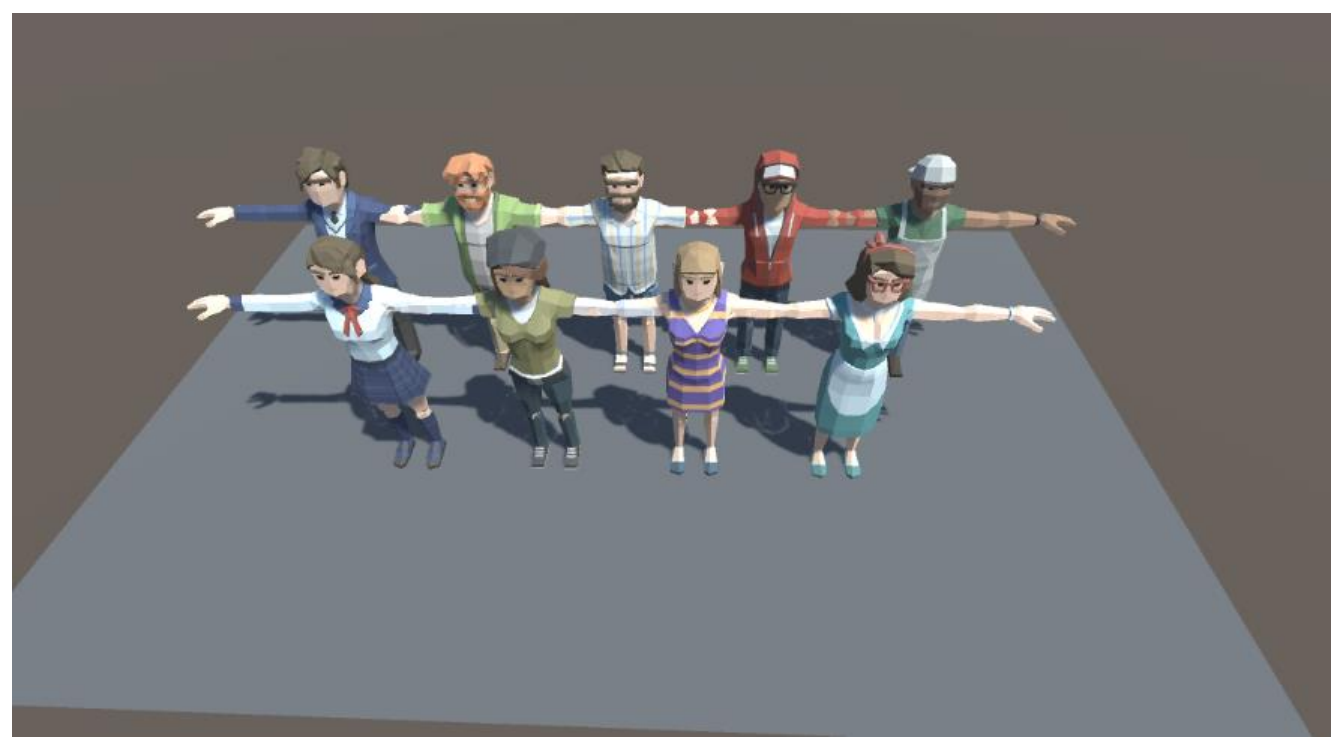

Figura 19: Personagens dos jogadores

\subsection{Tutorial de Reconhecimento e de Movimentação}

No tutorial de reconhecimento, o jogador é levado a uma cena onde estão presentes os personagens dos outros jogadores e alguns personagens inseridos aleatoriamente (Figura 20b). O jogador deve então clicar nos avatares que foram escolhidos pelos outros jogadores que estão participando da partida (Figura 20a). Esta atividade visa ajudar o jogador a diferenciar os personagens de jogadores dos outros que estarão presentes durante a partida ${ }^{4}$, já que este reconhecimento é importante para o aspecto multijogador do jogo. O desempenho neste tutorial é registrado em um log que anota quantos cliques foram feitos até que o jogador acerte a escolha dos companheiros de jogo.

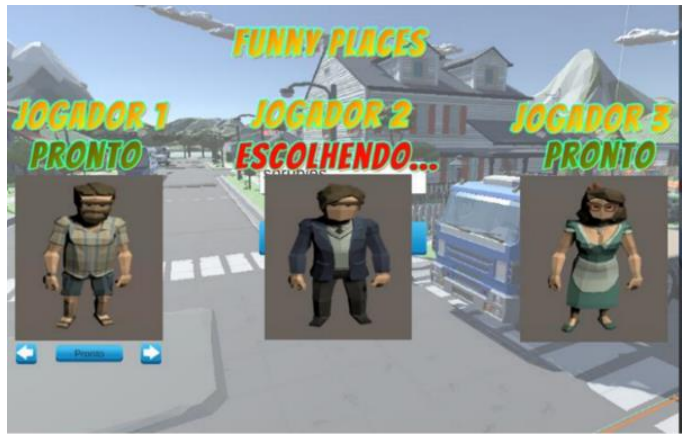

(a)

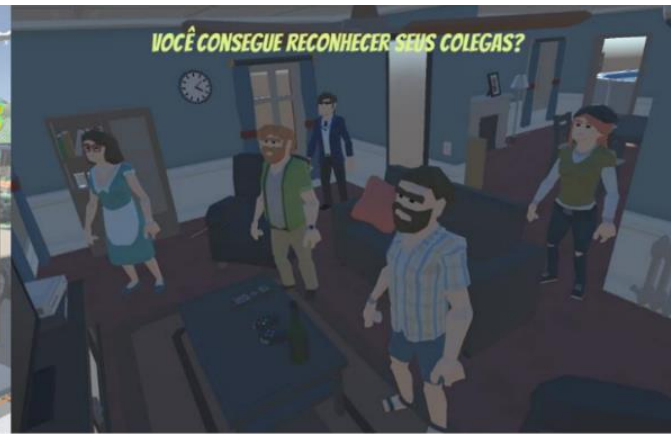

(b)

Figura 20: (a) Tela de seleção dos personagens. (b) Tutorial de Reconhecimento

\footnotetext{
${ }^{4}$ Chamamos de NPC (Non-Player Character) o personagem controlado pelo próprio jogo. Em geral os NPCs são agentes autônomos com algum grau de Inteligência Artificial.
} 
Já no tutorial de movimentação, os jogadores têm a opção de se mover livremente pela cidade, com os mesmos controles que terão no jogo principal. Esta experiência visa familiarizá-los com os controles e, durante ela, são guardadas informações como a distância total percorrida e a quantidade de cliques dados em tentativas de interagir com o cenário.

\subsection{Missão principal}

A missão principal do jogo é informada no hotel onde cada jogador começa o jogo. Lá eles recebem a informação de que seu grupo de amigos planejou uma festa surpresa para um membro do grupo. Para tanto, o jogador deve buscar 3 itens espalhados pela cidade e traze-los de volta ao hotel, para que então ele receba a informação de onde será organizada a festa (Figura 21). Diversos mecanismos de jogo se misturam a esta missão, como uma barra de vigor do personagem ou a possibilidade de entregar um bônus em dinheiro para outro jogador. A mensagem que os jogadores recebem no hotel pode conter ou não informações sobre estas mecânicas, sendo este mais um fator de configuração do jogo. Desta forma, é possível dar uma orientação mais dirigida aos jogadores ou permitir que descubram à medida que jogam.

O jogador tem uma quantidade limitada de créditos para comprar os itens e deve controlar seus gastos. Alguns itens podem ser comprados além dos que estão na lista, mas isto pode deixar o jogador sem recursos para os itens da lista. Após retornar ao hotel, o jogador recebe a informação de onde será realizada a festa e deve se dirigir até lá. No local da festa os jogadores visualizam uma mesa de festa com os itens que coletaram entre outros, e o jogador que obteve a melhor pontuação recebe um prêmio: um sobrevoo pela cidade (Figura 22). O jogador recebe uma mensagem na tela perguntando se ele deseja levar os companheiros no passeio e, em caso positivo, todos os participantes recebem o sobrevoo. 


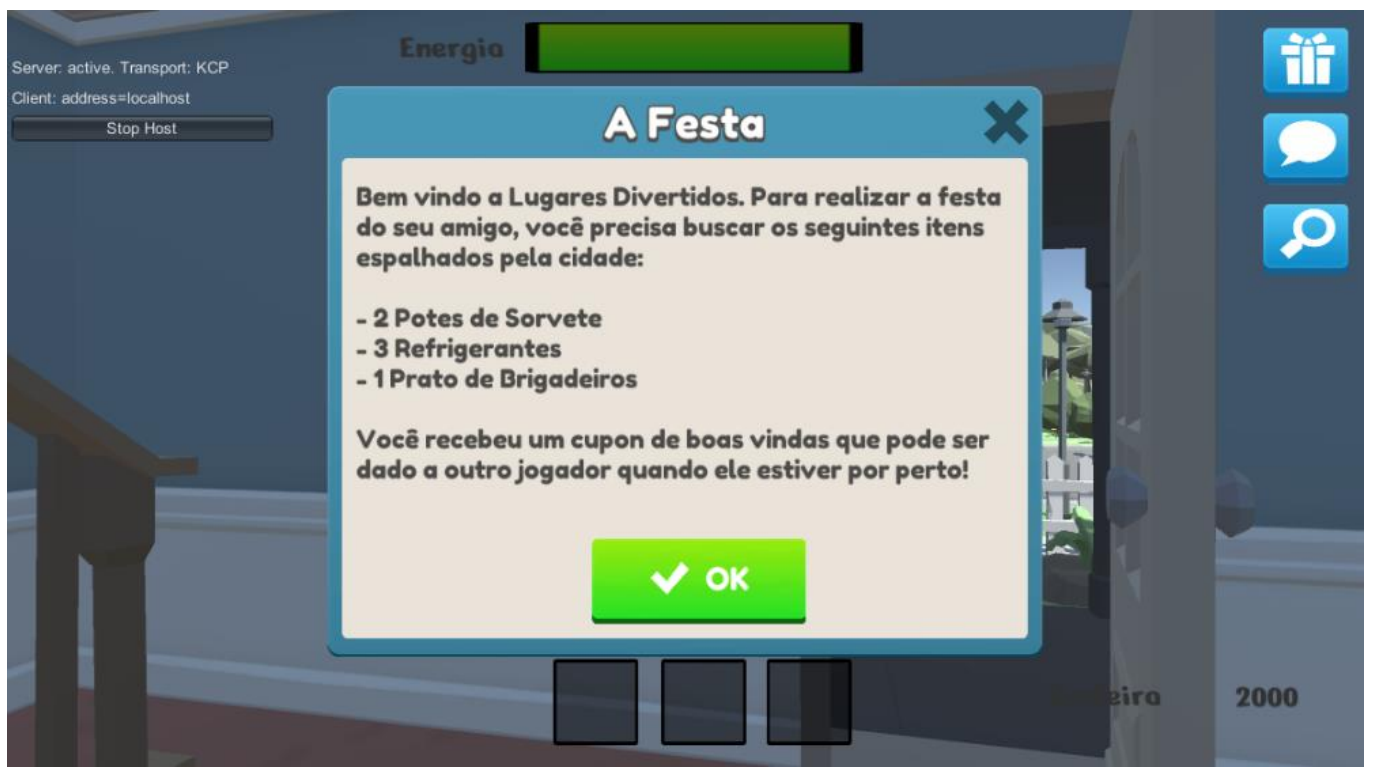

Figura 21: Tela de recebimento da missão

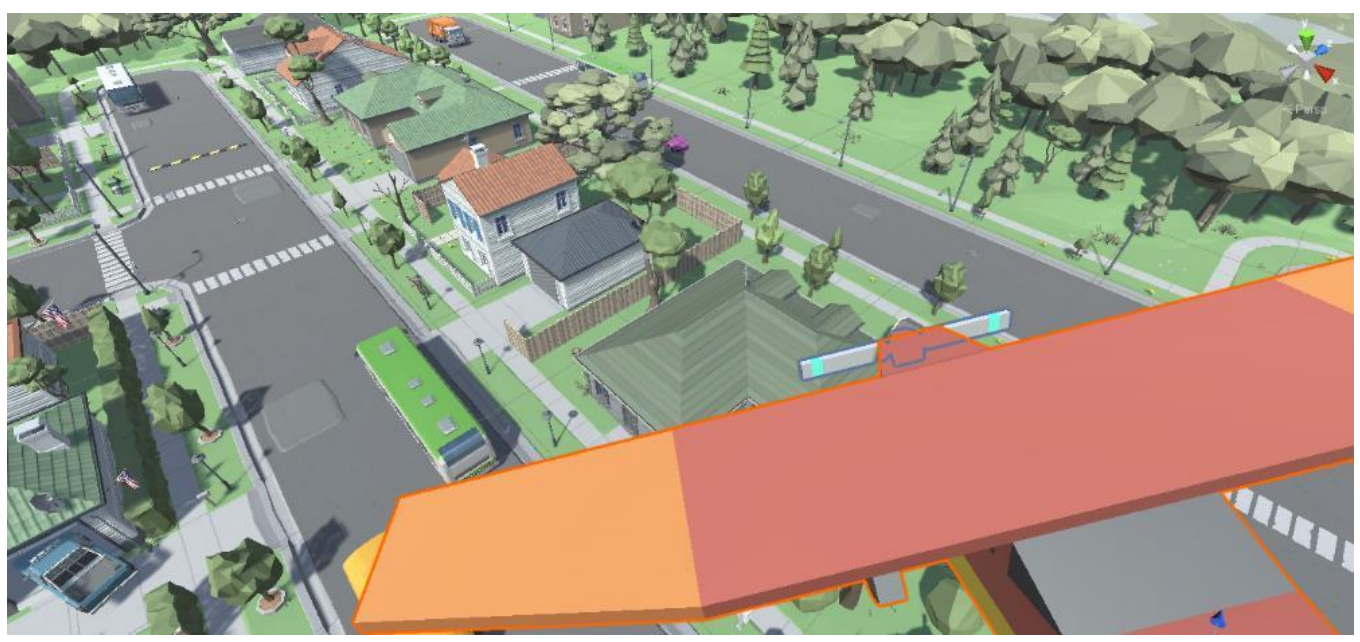

Figura 22: Cena de Sobrevoo

\subsection{Lista de Itens}

Após receber no hotel a lista de itens, o jogador deve partir para buscá-los na cidade. Um botão na interface permite que a lista seja exibida novamente na tela e sob cada item da lista há um botão para exibir a dica daquele item (Figura 23). A 
quantidade de vezes que o jogador clica para ver a lista de itens e a quantidade de vezes que clica no botão de dica são registradas no log da partida.

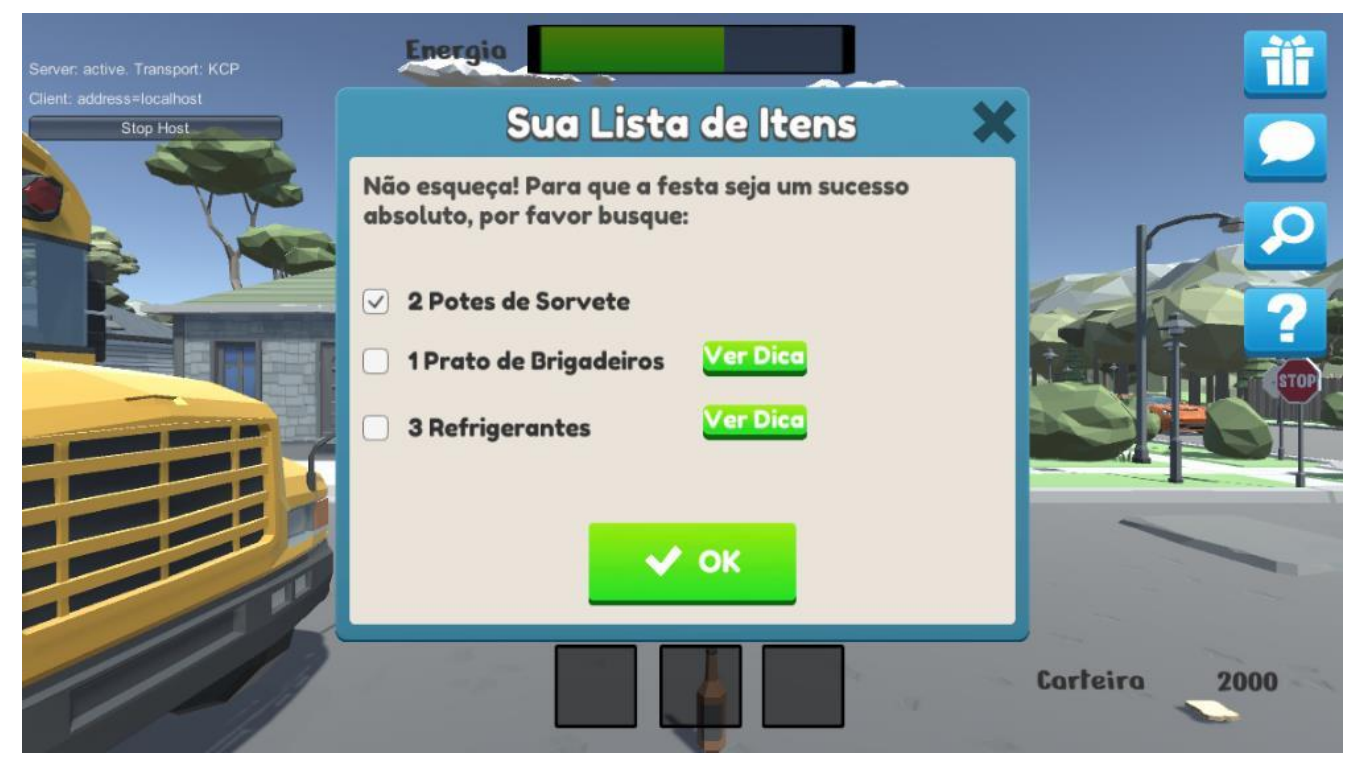

Figura 23: Lista de itens exibida na tela

\subsection{Barra de Energia}

$\mathrm{Na}$ interface há uma barra de energia do personagem do jogador. Andar pela cidade consome energia. Quando a energia se esgota o jogador passa a andar vagarosamente, como se estivesse se arrastando pelo cansaço. Existem duas formas de recarregar as energias. Uma é hidratando-se em uma das bancas de limonada espalhadas pela cidade. Comprar uma limonada consome uma quantidade pequena de créditos e recarrega metade da energia do jogador. Outra maneira de recarregar as energias é encontrar um amigo para conversar. Esta é uma atividade que impulsiona o aspecto multijogador do game. Ao estar perto de um jogador, o botão com ícone de balão de diálogo fica habilitado e o jogador pode clicá-lo e receber o efeito de uma conversa com um amigo: sua energia será completamente recarregada, além de receber um aumento na velocidade de movimento que dura 1 minuto. A interação nesta primeira versão do jogo é unidirecional, e não depende de aceite ou não do outro jogador que esteja perto, o qual pode clicar em seu próprio botão de interação para receber os benefícios. Algumas destas atividades geram dados que são coletados no log do jogo. 


\subsection{Itens Compostos e Itens com Prioridade}

Alguns dos itens que os jogadores devem buscar precisam ser combinados para serem concluídos. Por exemplo, se a lista do jogador contiver bolo de aniversário, ele deve comprar o bolo em uma padaria, mas em seguida precisa ir a uma loja de conveniência comprar velas para o bolo. Ao comprar os dois itens, automaticamente eles se combinam e esta parte da missão é dada como atendida. Outra possibilidade é o jogador precisar buscar itens que tem um limite de tempo após adquiridos. Por exemplo, o refrigerante esquenta após alguns minutos e o sorvete derrete (Figura 24). Desta forma, estes itens devem ser buscados por último, antes de o jogador voltar ao hotel. Não há trava para que ele os compre em primeiro lugar, mas caso o faça, ele corre o risco de precisar comprá-los novamente, reduzindo suas reservas de créditos.

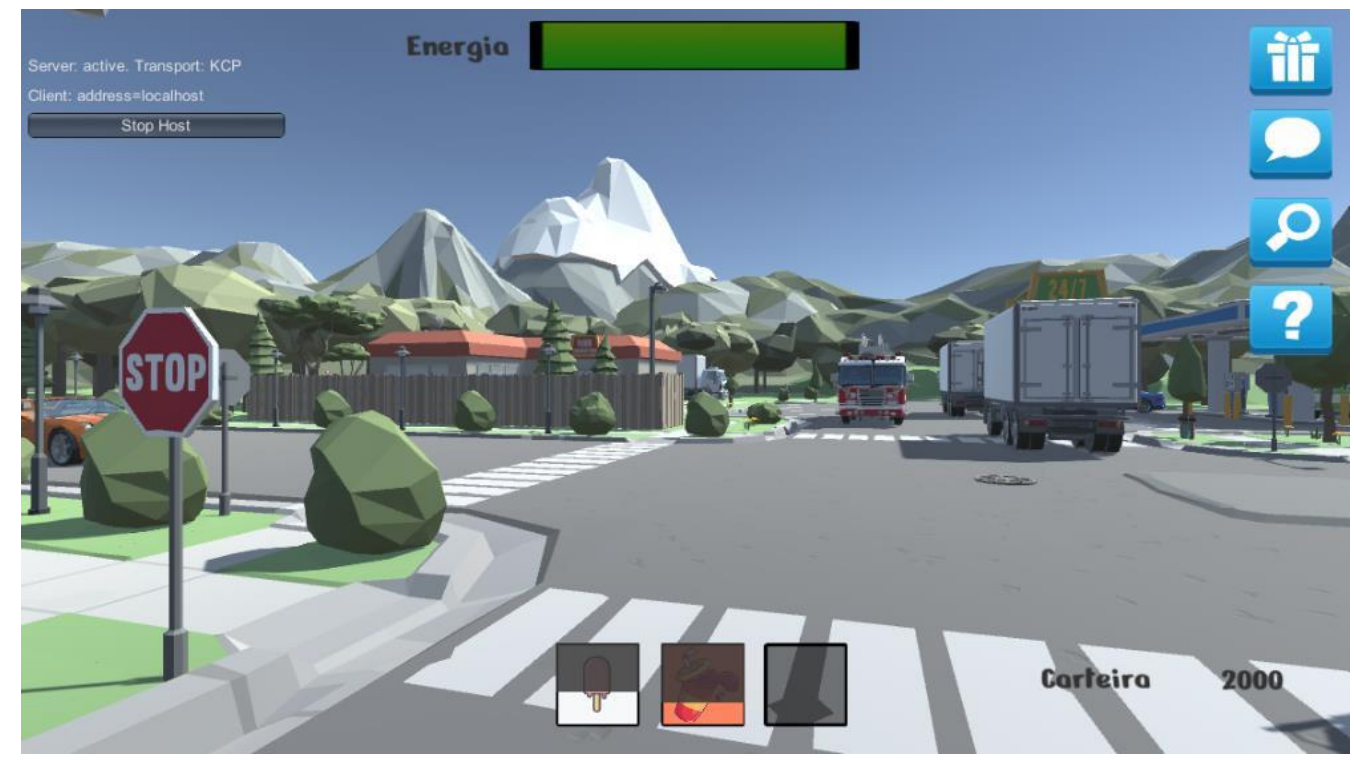

Figura 24: Interface mostrando sorvete derretendo e outros indicadores

\subsection{Bônus em Créditos}

Inicialmente, no hotel, o jogador recebe um cupom de bônus, que pode ser dado a outro jogador. Da mesma forma que o botão de interação fica disponível para ser acionado quando um jogador está próximo, o botão de doação de cupom também fica. Ao clicar nele, o jogador mais próximo recebe um bônus de créditos e é informado, por meio de uma mensagem na tela, que o outro jogador o beneficiou. Toda vez que um jogador compra um item que está em sua lista de compras, ele recebe um cupom e é informado que é uma promoção na cidade para incentivar a 
amizade. O jogador só pode ter um cupom por vez, não sendo possível acumulálos. Da mesma forma que o botão de interação por conversa, o botão de bônus de crédito tem os seus acionamentos registrados.

\subsection{Busca pelos Amigos}

$\mathrm{Na}$ interface do jogador, há um botão que ao ser clicado exibe na tela uma seta indicando a direção do jogador mais próximo (Figura 25). Ao ser acionado a seta é exibida por cerca de 10 segundos, apontando sempre para o jogador mais próximo. Após o clique, o botão fica desabilitado por um minuto. Os acionamentos deste botão também são registrados, bem como se o jogador tentou acioná-lo enquanto ele não estava disponível.

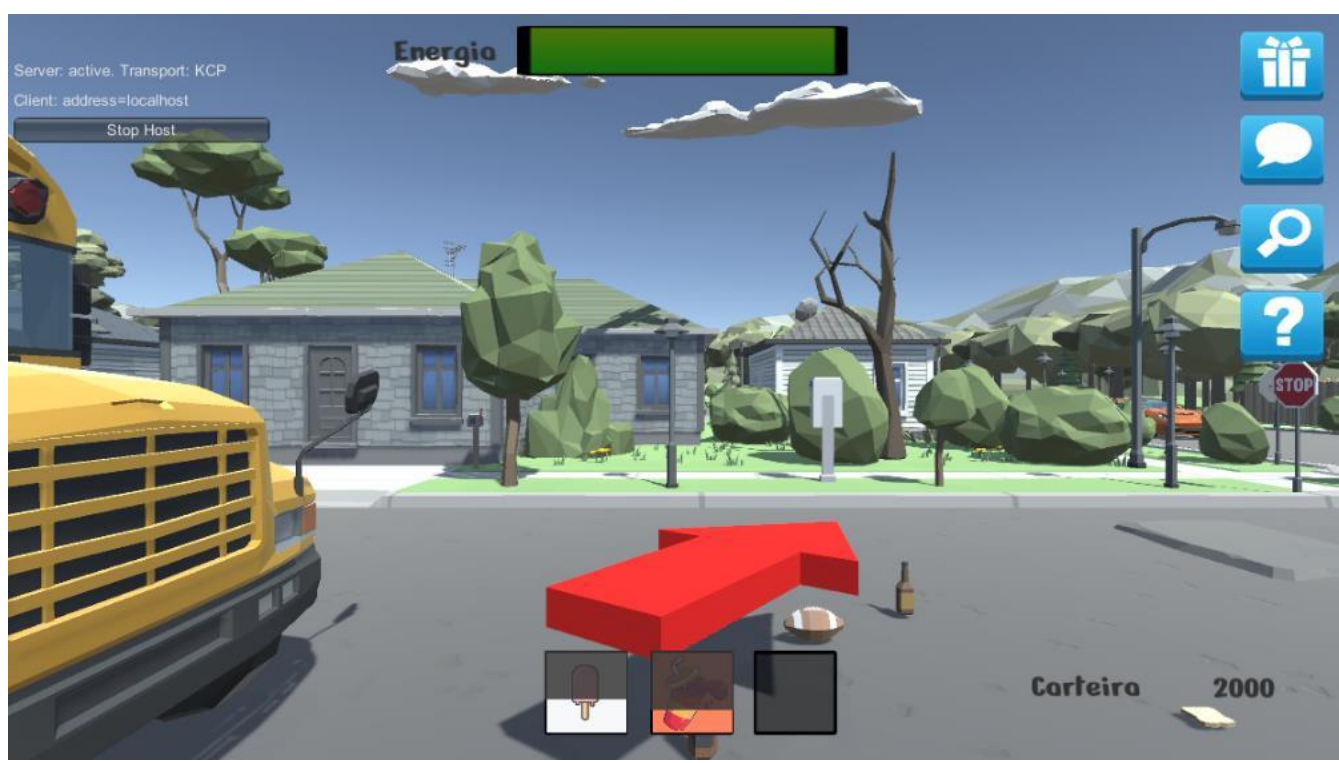

Figura 25: Seta apontando para jogador mais próximo

\subsection{Aquisição de Itens}

Para comprar os itens o jogador precisa fazer uma conta, em geral simples, da quantidade de itens vezes custo unitário. Todas estas informações são exibidas em uma interface quando o jogador clicar no item. Nesta mesma interface, é exibida uma máquina de cartão de crédito ao jogador (Figura 26), que deve digitar o valor que deseja pagar. Se o valor digitado for igual ou maior ${ }^{5}$ ao custo dos itens, o

\footnotetext{
${ }^{5}$ A ideia aqui é que, ao pagar um valor igual ou maior que o custo dos itens, o jogador possa leválos. Pensando em game analytics, este procedimento pode servir, por exemplo, para identificar um jogador que não faz a conta, mas chuta um valor elevado para conseguir o item. Pagar mais pode
} 
jogador passa para a próxima etapa, que envolve a exibição por alguns segundos da senha do cartão na tela e a digitação dela na máquina. A necessidade ou não de fazer a conta do valor a ser pago e o tamanho da senha do cartão são opções configuráveis pelo controlador ou psicólogo antes do início do jogo. A cada erro, a senha é exibida novamente na tela para relembrar ao jogador.

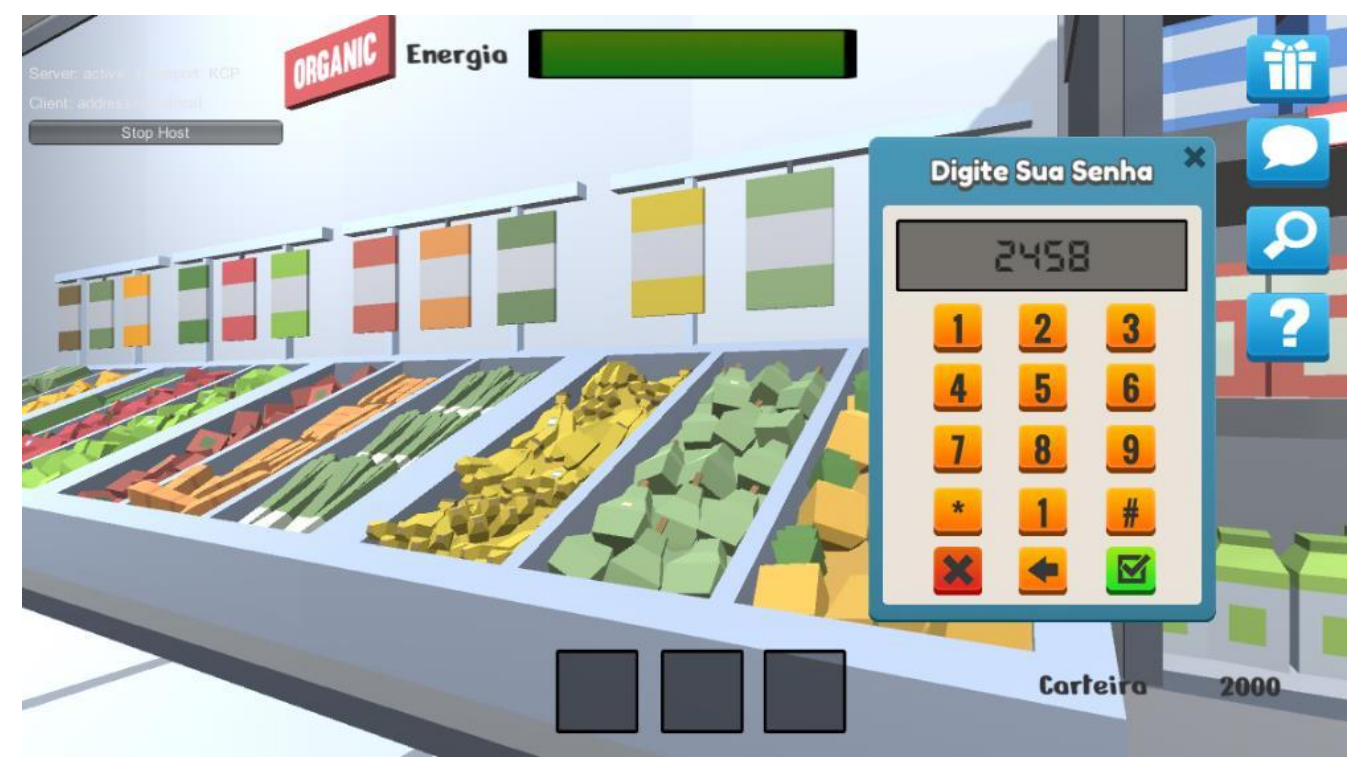

Figura 26: Máquina do cartão de crédito

\subsection{Conclusão do Jogo}

Após retornar ao hotel e entregar os itens coletados o jogador recebe a informação de onde será realizada a festa para o seu colega. A ida até o local da festa também faz parte das etapas de avaliação e, após a entrega dos itens, o botão que antes mostrava a lista de itens passa a exibir uma seta na tela indicando o caminho para a reunião.

Ao chegar ao local da reunião, o jogador recebe uma mensagem de parabéns, que também informa que ele deve aguardar a chegada de seus outros amigos. Quando todos chegam é exibida uma cena com a mesa do bolo, povoada pelos itens obtidos e mais alguns (Figura 27). O jogador que obteve a melhor pontuação recebe uma mensagem dizendo que ganhou um prêmio: um sobrevoo pela cidade. Imediatamente lhe é oferecida a oportunidade de estender o convite aos seus 
amigos. Caso o faça, todos participam do passeio. O comportamento do jogador neste episódio final pode ser relevante para o diagnóstico feito pelo controlador (psicólogo).

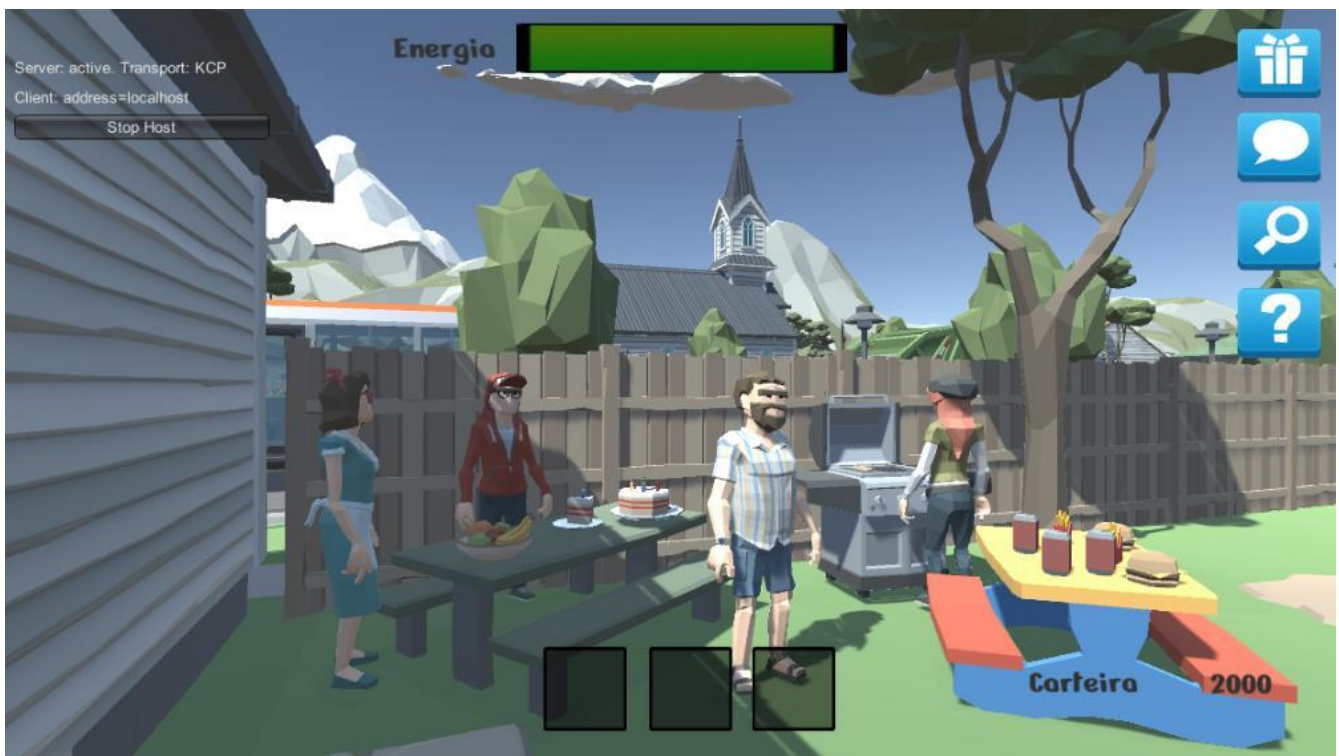

Figura 27: Festa ao final de uma partida

\subsection{Elementos de Distração}

Alguns objetos no cenário reagem à interação do jogador. Por exemplo, algumas árvores, ao receberem um click do mouse, disparam a animação de um passarinho que sai voando. Da mesma forma, um gato pode sair correndo quando o jogador clica em alguns dos carros espalhados pela cidade. Estas atividades são tidas como elementos de distração e há um registro de quantas vezes o jogador disparou uma animação destas, bem como quantas vezes ele fica parado tentando disparar novamente a mesma animação. Também é contabilizado o tempo de distração em qualquer parada mais longa no cenário para observar o ambiente.

\subsection{Imprevistos}

Há alguns imprevistos possíveis de ocorrerem no decorrer da partida, como a falta de um item em um determinado estabelecimento (o que obriga o jogador a buscar esse item em um outro lugar). Por exemplo, a lista de itens que o jogador recebe pode conter 3 refrigerantes, mas a loja em que ele entrou só possui dois para vender. Este tipo de imprevisto visa medir a capacidade do jogador de se adaptar, ou mesmo seu autocontrole emocional. Outros imprevistos possíveis são ter que 
recomprar um item que caiu no chão ou voltar para procurar um item que desapareceu do inventário do jogador. Estes imprevistos podem ser habilitados ou desabilitados pelo controlador antes do início do jogo e, quando habilitados, podem ocorrer aleatoriamente a qualquer momento. Em versões futuras, o psicólogo poderá criar um imprevisto em tempo real.

\subsection{Missões e Funções Executivas}

O principal objetivo de Lugares Divertidos é avaliar as funções executivas. Em sua primeira versão, tal como é descrita nesta dissertação, o jogo pretende apenas fazer diversos registros de dados e propor formas de medir as funções executivas. Em versões futuras, pretende-se diagnosticar e, se possível, treinar o uso destas funções. Um dos grandes diferenciais de Lugares Divertidos é o contexto, que garante que funções executivas sejam avaliadas de forma realista durante a participação no jogo, medindo o desempenho em tarefas muito parecidas com tarefas do dia a dia.

As atividades do jogo foram baseadas em testes psicológicos que são usados para medir funções executivas, mas, em vez de fazer uma interface digital para estes testes, a proposta foi inseri-los de forma imperceptível ao jogador, tais como um teste de memória para se lembrar dos companheiros de jogo (tutorial de reconhecimento) ou um teste de memória de trabalho para digitar a senha correta do cartão de crédito (lembrando que o tamanho da senha é uma das configurações realizadas pelo psicólogo que define e/ou controla o jogo).

Nesta versão do jogo, foram avaliadas algumas funções executivas, embora não todas, mas espera-se, com a implementação de novas missões e mecânicas, poder avaliar novas funções. A Tabela 2 ilustra as funções executivas, mostrando como são detectadas e medidas durante o jogo.

Tabela 2: Tabela de detecção e medição de funções executivas

\begin{tabular}{|c|c|c|}
\hline Função / Conceito & Como é Detectada & Como Pode Ser Medida \\
\hline $\begin{array}{l}\text { Autocontrole } \\
\text { Emocional } \\
\text { Capacidade do paciente de } \\
\text { superar um obstáculo ou realizar }\end{array}$ & $\begin{array}{l}\text { - Limite de tempo para } \\
\text { encontrar os objetos. } \\
\text { - Reação do jogador ao } \\
\text { "perder" um item (evento que }\end{array}$ & $\begin{array}{l}\text { - Cruzamento do log do } \\
\text { jogo com o log de um } \\
\text { aparelho de batimentos } \\
\text { cardíacos }\end{array}$ \\
\hline
\end{tabular}


um desafio que promova pode ser disparado pelo reatividade emocional
-Monitoramento das expressões faciais do jogador (44)

- Quantidade e tempo de animações contempladas, as quais podem ser disparadas por meio de interação com o cenário. Capacidade de focar na atividade solicitada e inibir estímulos de distração e outras atividades mesmo que prazerosas

Manter-se na tarefa de
procurar os itens
determinados e evitar
distrações do tipo explorar o
ambiente, ficar apreciando
animações e jogar
indiscriminadamente mini
games.

- Razão entre distância total percorrida e distância necessária para alcançar um objeto.

- Manter a informação da senha do cartão de crédito (configurável pelo psicólogo, de 1 a 7 dígitos) e digitá-la corretamente para comprar um objeto. A cada erro a senha é exibida novamente na tela.

\section{Memória de Trabalho}

Capacidade de manter de forma transitória uma informação verbal ou visuoespacial necessárias para realização de uma atividade.

\section{Flexibilidade Cognitiva}

Mudar ou ajustar a missão em decorrência de algum obstáculo.

\section{Planejamento}

- Calcular o valor a ser pago (e.g., 5 unidades de um item a um preço unitário de $\$ \mathrm{xxx}$ ).

- Memorizar os itens que precisa buscar e a dica de onde se encontram (há um botão que permite ver a lista de itens e as dicas a qualquer momento, porém com algumas restrições, tais como número máximo de vezes ou intervalo de tempo antes de usar a informação).

- Falta de um item em uma loja obriga o jogador a ir a outra para adquiri-lo.

- Necessidade de combinar dois itens complementares (e.g. combinar bolo e velas para fazer 0 bolo de aniversário).

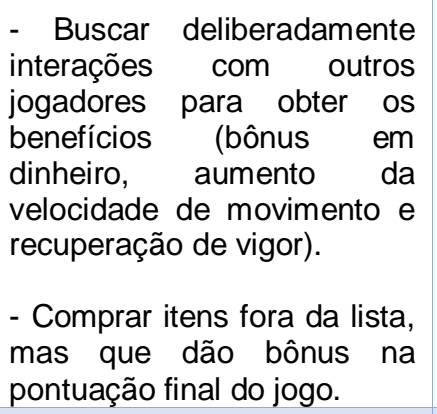

- Buscar os itens na ordem apropriada (sorvete que
- Quantidade de tentativas até digitar corretamente a senha. ${ }^{6}$

- Tempo gasto para digitar a senha.

-Quantidade de tentativas até calcular corretamente o valor da compra.

- Tempo até calcular o valor da compra.

- Quantidade de vezes que o botão de dica de itens é acionado.

- Capacidade de buscar o item em outra loja seja por falta ou por necessidade de combinar dois itens.

- Quantidade de interações com outro jogador.

- Quantidade de vezes que - botão que indica a localização do jogador mais próximo foi pressionado.

- Quantidade de itens de bonificação adquiridos.

Respeito à prioridade de coleta dos itens.

\footnotetext{
${ }^{6}$ Esta fórmula e outras estão descritas na seção 4.18, como uma primeira tentativa de mensuração de funções executivas e comportamentos. Em uma futura investigação, a partir da aplicação intensa do jogo e com a ajuda de psicólogos, poderemos ajustar ou até mesmo criar novas fórmulas. $\mathrm{O}$ software foi projetado para que este ajuste seja bastante fácil.
} 


\begin{tabular}{|c|c|c|}
\hline $\begin{array}{l}\text { Capacidade de organizar e } \\
\text { planejar os passos necessários } \\
\text { para a realização de uma } \\
\text { determinada atividade. }\end{array}$ & $\begin{array}{l}\text { derrete tem que ser o último } \\
\text { item). } \\
\text { - Retorno ao hotel apenas } \\
\text { após obter todos os itens. } \\
\text { - Equilíbrio entre velocidade e } \\
\text { erro na execução } \\
\text { - Comportamentos } \\
\text { desejáveis que são } \\
\text { premiados (por exemplo, a } \\
\text { interação social é sempre } \\
\text { premiada) }\end{array}$ & $\begin{array}{l}\text { - Tentativa de retornar ao } \\
\text { hotel antes de obter todos } \\
\text { os itens. }\end{array}$ \\
\hline $\begin{array}{l}\text { Monitoração } \\
\text { Capacidade de monitorar a } \\
\text { missão ao longo do processo de } \\
\text { execução. }\end{array}$ & $\begin{array}{l}\text { - Controlar o dinheiro da } \\
\text { carteira e comprar os itens } \\
\text { corretos. } \\
\text { - Supervisionar o nível de } \\
\text { cansaço e buscar forma de } \\
\text { se recuperar para não ficar } \\
\text { esgotado. }\end{array}$ & $\begin{array}{l}\text { - Capacidade de adquirir } \\
\text { todos os itens com o } \\
\text { dinheiro dado. } \\
\text { - Quantidade de vezes que } \\
\text { a barra de energia se } \\
\text { esgotou. } \\
\text { - Quantidade de vezes que } \\
\text { um item ou atividade de } \\
\text { recuperação de energia foi } \\
\text { acionado. }\end{array}$ \\
\hline $\begin{array}{l}\text { Interação Social } \\
\text { Engajamento do jogador em } \\
\text { atividades com outros jogadores, } \\
\text { aproveitando-se do aspecto } \\
\text { multijogador do jogo para } \\
\text { interagir socialmente, seja } \\
\text { apenas para se socializar, seja } \\
\text { para obter vantagens no jogo ou } \\
\text { obter facilidades }\end{array}$ & $\begin{array}{l}\text { - Buscar outro jogador para } \\
\text { entregar um bônus em } \\
\text { dinheiro (em algumas } \\
\text { ocasiões, o jogador recebe } \\
\text { um bônus que só serve para } \\
\text { outro jogador). } \\
\text { - Usar os emojis disponíveis } \\
\text { para se comunicar } \\
\text { - Procurar outro jogador no } \\
\text { mapa para, por meio de um } \\
\text { botão de interação, recuperar } \\
\text { energia. }\end{array}$ & $\begin{array}{l}\text { - Acionamento do botão de } \\
\text { interação multijogador } \\
\text { quando disponível (o botão } \\
\text { fica em destaque quando } \\
\text { há outro jogador próximo o } \\
\text { suficiente para que haja } \\
\text { interação). } \\
\text { - Quantidade de vezes que } \\
\text { o botão que mostra a } \\
\text { localização do jogador mais } \\
\text { próximo foi acionado. }\end{array}$ \\
\hline
\end{tabular}

Os métodos de medição do autocontrole emocional levantados, dependem de dispositivos externos, como um medidor de batimentos cardíacos ou uma câmera e um algoritmo de processamento das expressões do jogador (44). Estes métodos foram listados como possibilidades. Não foi levantada nenhuma forma de medição do autocontrole emocional diretamente por variáveis do jogo. Embora se acredite que o ato de clicar muitas vezes no mesmo lugar pode denotar impaciência ou ansiedade. No entanto, este comportamento poderia estar relacionado a perseveração, que aparece em déficits mais graves de funções executivas; sendo assim, será necessário um estudo mais aprofundado para tirar conclusões do estado emocional do jogador somente com variáveis do jogo.

\subsection{Game Analytics}

Game Analytics diz respeito ao processo de coleta de dados durante uma partida de algum jogo digital. Estes dados podem incluir desde quanta munição um jogador 
desperdiça até quanto tempo ele fica parado observando algum elemento do jogo. Em jogos do tipo multijogador online, por exemplo, a análise dos dados coletados pode direcionar as atualizações futuras, de forma a agradar mais a audiência. Mesmo em jogos offline de jogador único é frequente que o jogador se depare com uma mensagem logo no início do jogo, informando que a desenvolvedora coleta dados para melhorar a experiência de jogo.

Outra possibilidade é a determinação do perfil do jogador, como em (45) e (46), provendo insumos para que o jogo se adapte de maneira a prover uma experiência mais agradável ao jogador, ou ainda, a coleta de dados de uso da interface e da forma como o participante joga, o com o intuito de melhorar a usabilidade do software.

Neste trabalho, as técnicas de game analytics foram usadas para viabilizar a avaliação das funções executivas, tendo sido implementadas diversas métricas.

Tabela 3: Dados contabilizados durante uma partida de Lugares

Divertidos

\begin{tabular}{|l|l}
\hline Métrica & \\
\hline M1 & Distância total percorrida \\
\hline M2 & Total de dinheiro gasto \\
\hline M3 & Tempo para digitar a senhão \\
\hline M4 & Tempo para encontrar jogadores no tutorial \\
\hline M5 & Distância percorrida durante o tutorial \\
\hline M6 & Dificuldade dos itens listados \\
\hline M7 & Quantidade de vezes que se hidratou \\
\hline M8 & Valor da barra de energia quando se hidratou \\
\hline M9 & Acionamentos do botão de interação social \\
\hline M10 & Acionamentos do botão de doação de cupom \\
\hline M11 & Acionamentos do botão de jogador mais próximo \\
\hline M12 & Recuperação de um item perdido \\
\hline M13 & Tamanho da senha digitada \\
\hline M14 & Razão entre o valor da compra e valor dos itens \\
\hline M15 & Quantidade de vezes que a energia se esgotou \\
\hline M16 & Ordem de aquisição do item com prioridade \\
\hline M17 & Obtenção de item de combinação quando ocorreu oportunidade \\
\hline M18 & Quantidade de vezes que cada botão de interação ficou disponível \\
\hline M19 & Quantidade de animações acionadas \\
\hline M20 & Créditos ao final da partida \\
\hline M21 & Opção de levar os amigos para o sobrevoo \\
\hline M22 & Quantidade de dígitos da senha \\
\hline
\end{tabular}




\begin{tabular}{l|l}
\hline M23 & Quantidade de dígitos corretos ao digitar a senha \\
\hline M24 & Tentativas até digitar a senha corretamente \\
\hline
\end{tabular}

Em um primeiro momento o que se pretende é viabilizar a coleta de dados e disponibilização deles para que um psicólogo possa avaliar o desempenho dos jogadores no que diz respeito às funções executivas. Ainda que teoricamente e ainda sem testes em campo, foram propostos algoritmos para quantificar o desempenho nas funções executivas. Tais algoritmos serão aprimorados em versões futuras de Lugares Divertidos.

Durante uma partida de Lugares Divertidos os clientes enviam alguns comandos ao servidor para registrar ações do jogador durante a partida. As métricas coletadas estão apresentadas na Tabela 4.

Os dados ficam todos registrados no servidor no formato de arquivo separado por vírgulas, que contém a identificação de cada jogador e todas as métricas coletadas durante a partida. Também ficam registrados no arquivo os dados da partida, tais como a data em que ocorreu, a duração, e configurações do psicólogo utilizadas.

\subsection{O protótipo e as métricas utilizadas}

O primeiro protótipo de Lugares Divertidos está disponível para download em https://github/BrunoTas/FunnyPlaces. e, na presente versão, foram propostas algumas métricas para a avaliação das funções executivas. Estas métricas representam uma primeira tentativa de quantizar as funções dos jogadores e precisam ser validadas com o uso do jogo na clínica de psicologia da PUC-RIO e em outros ambientes supervisionados por psicólogos. Estas métricas podem ser totalmente modificadas após esta avaliação, podendo inclusive haver mudança nas variáveis que são coletadas durante o jogo. Espera-se que, após este processo, a pontuação atribuída a cada dimensão das FE esteja melhor caibrada e que seja possível traçar paralelos com algum dos testes clássicos da psicologia.

As métricas inicialmente propostas geram uma pontuação que começa em 100 pontos para as funções executivas e recebe penalidades e bonificações a depender 
das ações no jogo. A exceção é a pontuação de interação social, que começa em zero e recebe incrementos quando um jogador tenta interagir e decrementos quando ele ignora uma oportunidade de interação.

\section{- Memória de trabalho:}

$$
\begin{aligned}
& M T=100-(10-D c) .(1 \text { se erro, } 0 \text { se acerto })-a b s(V t-V p) \\
&+D c .(1 \text { se acerto, } 0 \text { se erro })
\end{aligned}
$$

$D c$ : Dígitos Corretos na Senha

$V t$ : Valor Total dos itens

$V p$ : Valor Pago pelos itens

Desta forma espera-se penalizar mais os erros em senhas fácies. Errar 1 dígito em uma senha de 3 dígitos resulta na perda de 9 pontos e errar 1 dígito em uma senha de 10 dígitos resulta na perda de 1 ponto apenas. A conta correta do valor a ser pago não penaliza o jogador, mas pagar a mais ou a menos, sim.

\section{- Autocontrole Cognitivo:}

$$
A C=100-A a * 5-\left(\frac{D t}{D m}\right) * 3
$$

Aa: acionamentos de animações com intervalos menores de 10s entre eles

$D t$ : distância total percorrida

Dm: distância mínima necessária para coletar os itens

Na métrica do autocontrole cognitivo penaliza-se jogadores que ficam andando a esmo pela cidade sem focar na tarefa de buscar os itens, bem como jogadores que gastam muito tempo acionando os elementos de distração encontrados ao longo do caminho.

\section{- Planejamento:}

$$
P=100-T h * 5-E a-I p f o * 5+10 * I c
$$

Th: tentativas de voltar ao hotel sem completar a missão

$E a$ : vezes que a energia acabou 
Ipfo: vezes que comprou um item prioritário fora de ordem

Ic: 1 se coletou corretamente o item composto, 0 caso contrário

$\mathrm{Na}$ pontuação do planejamento penalizam-se as tentativas de voltar ao hotel antes da hora e a falta de planejamento para manter a energia elevada. A busca bem sucedida de itens compostos gera bonificação.

\section{- Monitoração:}

$$
M=100-E a * 10-10 * D a+10 * R e
$$

$E a$ : vezes que a energia acabou

$D a: 1$ se o dinheiro acabou antes de obter todos os itens, 0 caso contrário

$R e$ : vezes que recuperou mais de 10 pontos de energia com hidratação

$\mathrm{Na}$ pontuação da monitoração penaliza-se o jogador que deixou sua energia acabar e aquele que deixou o dinheiro se esgotar antes de conseguir todos os itens, e bonifica-se o jogador que recuperou energia com recargas de hidratação, mas apenas aquelas que recuperaram um valor significativo de energia, de forma a evitar que o acionamento seguido e desnecessário gere pontuação.

\section{- Interação Social:}

$$
I S=B s * 2-B n s+B d+B l
$$

$B s$ : acionamentos do botão de interação social

Bns: vezes que o botão de interação social ficou disponível mais de 5 s e não foi acionado

$B l$ : vezes que o botão de localização do jogador mais próximo foi acionado

O Objetivo deste indicador é medir a pré-disposição do jogador para interagir socialmente. Por este motivo, bonifica-se as tentativas de encontrar outros jogadores e de ajudá-los. 


\section{Sistema Computacional}

O desenvolvimento de Lugares Divertidos foi feito no game engine Unity versão 2019.4.15.f1, que foi selecionado por ser uma opção de baixo custo e que permite a entrega de produtos com nível comercial, além de ter uma enorme comunidade muito ativa no desenvolvimento de games, o que facilita seu aprendizado. Outra razão para o uso do Unity é a facilidade de geração para várias plataformas (PC, celular, tablet).

Outra vantagem do Unity é a Unit Asset Store ${ }^{\mathrm{TM}}$ (https://assetstore.unity.com/), onde diversos componentes desenvolvidos por estúdios ou pela comunidade ficam disponíveis, alguns gratuitos e alguns pagos. Estes conteúdos são chamados de Assets. Os scripts gerados para o jogo foram feitos com C\# e os assets usados no desenvolvimento foram:

- Simple Shops (Synty Studios)

- Polygon Town (Synty Studios)

- Polygon City Characters (Synty Studios)

- Simple UI (Unruly Games)

- 500 Resource Icons (Poneti)

- $\operatorname{Mirror}(\mathrm{Vis} 2 \mathrm{~K})$

- Simple Airport (Synty Studios)

- Bird Cute Series (Meshtint Studio)

Para a movimentação dos personagens foram usadas animações disponíveis no site https://www.mixamo.com. Estas animações estão sob uma licença que permite o livre uso e até mesmo comercialização de jogos que as utilizem, havendo restrição apenas para a revenda das próprias animações.

\subsection{Networking}

$\mathrm{O}$ Unity apresenta uma solução nativa de $\mathrm{API}^{7}$ de alto nível para

\footnotetext{
${ }^{7}$ API (Application Programming Interfaces)
} 
desenvolvimento de aplicações multijogador: a Unet. Entretanto, a solução fornecida pelo Unity está marcada para ser descontinuada a partir de 2021. A nova proposta da empresa é fornecer as funcionalidades online por meio de um serviço de servidores dedicados, a qual promete ser muito completa, mas com um custo associado. Embora esta solução pareça uma boa opção para grandes jogos, com grande público, para os pequenos desenvolvedores e desenvolvimentos acadêmicos pode não ser adequada. Somado a isso, durante o desenvolvimento inicial do protótipo do jogo, esta nova solução nativa do Unity ainda não estava pronta, sendo apenas disponibilizada sua versão alpha. Pensando no desenvolvimento contínuo do jogo e para não ficar dependente de uma versão desatualizada do engine, foi buscada uma alternativa.

Foram comparadas duas soluções: Mirror Networking e o Photon Engine. O Photon (https://www.photonengine.com/) faz uma reescrita do código da API de baixo nível da Unity e se apoia principalmente em um modelo de servidores dedicados através de Cloud Servers (Figura 28). Além disso, o Photon apresenta dois tipos de soluções diferenciadas a depender do tipo de trafego e latência necessária para o jogo. O PUN atende a jogos em geral e BOLT é voltado a jogos de ritmo mais rápido, como jogos de tiro em primeira pessoa, que requerem um desempenho que atenda a requisitos mais rígidos de latência e taxas de transferência. Já o Mirror (https://mirror-networking.com/) é praticamente idêntico ao Unet, sendo basicamente uma reescrita dele (com mais de 950 bug fixes segundo os desenvolvedores). Foi feito um breve comparativo, mostrado na Tabela 4. 


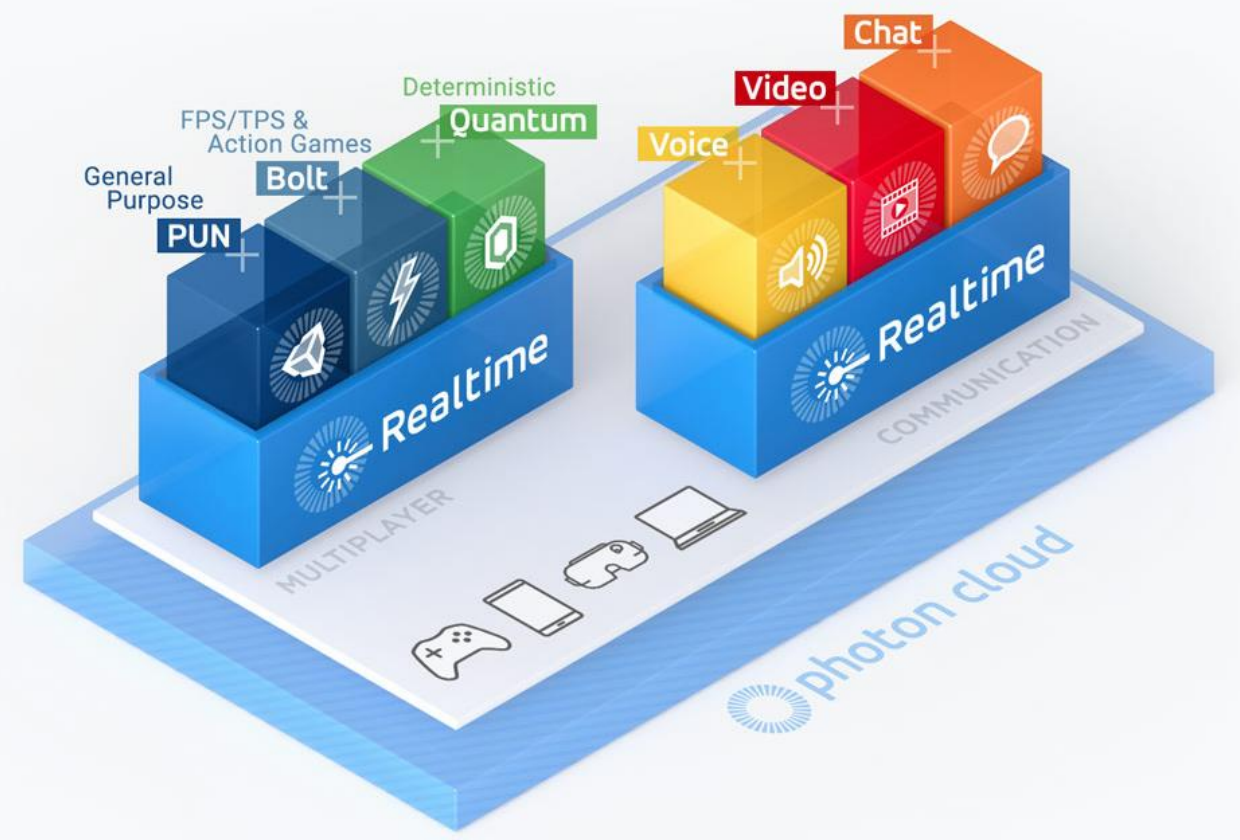

Figura 28: Família de soluções de rede do Photon

Tabela 4: Comparação entre Mirror e Photon

\begin{tabular}{|l|l|l|}
\hline \multicolumn{1}{|c|}{ Mirror } & \multicolumn{1}{c|}{ PUN2 (Photon) } & Mais pontos a favor \\
\hline $\begin{array}{l}\text { Totalmente gratuito e sem } \\
\text { limite de usuários }\end{array}$ & $\begin{array}{l}\text { Gratuito até 20 jogadores } \\
\text { simultâneos. }\end{array}$ & Mirror \\
\hline $\begin{array}{l}\text { Muitos tutoriais disponíveis e } \\
\text { desenvolvedores disponíveis } \\
\text { pelo Discord® }\end{array}$ & $\begin{array}{l}\text { Maduro e com muitos } \\
\text { tutoriais disponíveis. }\end{array}$ & Empate \\
\hline $\begin{array}{l}\text { Baseado no Unet } \\
\text { (praticamente idêntico ao }\end{array}$ & & \\
$\begin{array}{l}\text { Unet, o qual é amplamente } \\
\text { usado em disciplinas básicas } \\
\text { de graduação e pós- } \\
\text { graduação) }\end{array}$ & $\begin{array}{l}\text { Reescrita da API de baixo } \\
\text { nível da Unity. }\end{array}$ & Mirror \\
\hline
\end{tabular}

Modelo Cliente Servidor com um cliente atuando como Host.

Caso necessário tem suporte a servidores dedicados.
Modelo cliente via cloud server.

Mirror

Modelo com servidores via nuvem ou servidores privados. Ambas as opções tem custos a partir Empate de um determinado número de jogadores simultâneos. 
Por conta dos pontos aqui levantados, foi selecionado o Mirror Networking como solução para as funcionalidades de multijogador necessárias para o jogo Lugares Divertidos. Acredita-se que o jogo inicialmente possa ser utilizado no departamento de Psicologia da PUC-Rio, mas com a possibilidade do uso acadêmico em outras universidades. Além do mais, a possibilidade de implementação de um modelo gratuito, sem limite de jogadores simultâneos, viabilizado pelo Mirror, pesou muito na escolha. Espera-se que versões futuras do game, orientadas ao treinamento de funções executivas, possam ser distribuídas para uma quantidade maior de usuários, caso no qual talvez fosse interessante ter salas de jogo dedicadas. O Mirror ainda oferece a possibilidade deste tipo de implementação e, em vista dessas razões, não havia porque não utilizá-lo.

\subsection{Mirror Networking}

O Mirror Networking, opção selecionada para implementar as funcionalidades de rede de Lugares Divertidos, usa um modelo Cliente-Servidor, com um cliente atuando como host, como pode ser visto na Figura 29.

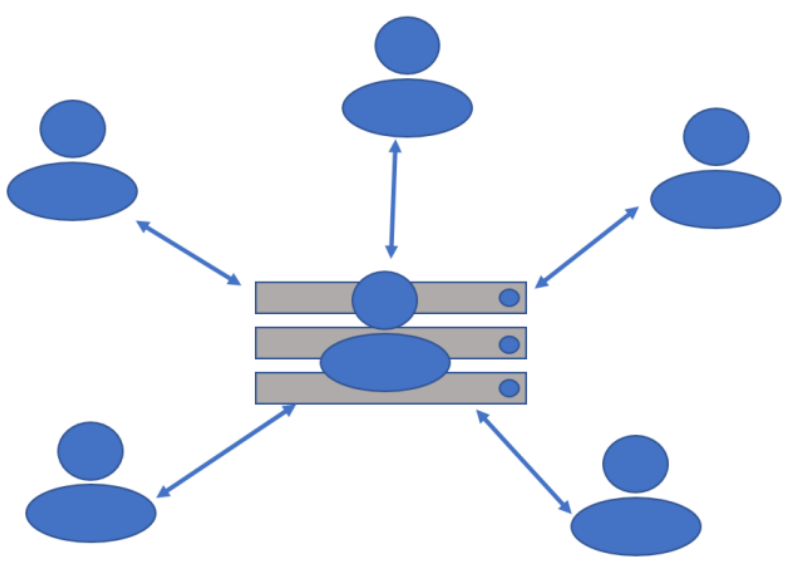

Figura 29: Modelo de conexão do Mirror (fonte: do autor)

Este tipo de arquitetura coloca um pouco mais de estresse no cliente que atua como host, além de apresentar uma ligeira vantagem para o host que jogaria sem latência, além da facilidade de cheats (trapaças ou vantagens obtidas pela manipulação de variáveis no servidor). Entretanto, para o uso esperado de Lugares Divertidos em seu estágio atual, é este o layout perfeito, já que o host atua apenas como servidor e é ocupado pelo controlador ou psicólogo a quem cabe o controle 
sobre o jogo.

Caso seja necessário ter ganho de escala, o Mirror pode ser usado com servidores dedicados bem como combinado com soluções de matchmaking, permitindo que jogadores em celulares possam se conectar a seus amigos, por exemplo.

Com o uso do Mirror, não há necessidade de códigos diferentes para cliente e servidor - eles podem ser o mesmo projeto, razão do nome Mirror (47).

O Mirror oferece o uso de tags no código que identificam o tipo de comunicação, são elas:

- [Server] / [Client]: usadas para limitar trechos de código a rodar apenas no cliente ou apenas no servidor

- [Command]: usadas para comunicação cliente servidor

- $\quad$ [ClientRpc] / [TargetRpc]: usadas para comunicação servidor cliente

- $\quad$ SSyncVar]: usadas para sincronizar dados

Neste contexto, por exemplo, [Command] pode ser usado para que um cliente sinalize para o servidor que um objeto foi coletado. Desta forma o servidor irá informar aos clientes que aquele objeto não existe mais. [ClientRpc] pode ser usado para que o servidor informe ao cliente que deve criar algum objeto e [Syncvar] pode ser usado para sincronizar a barra de energia de diferentes jogadores, de forma que todos vejam valores atualizados de energia.

\subsection{Diagrama de Classes}

O diagrama de classes (Figura 30) mostra a disposição das principais classes do jogo, que em sua maioria herdam da classe NetworkBehaviour, do Mirror, e que fornecem muitos dos comportamentos necessários para a comunicação online e a viabilização do jogo multijogador. A descrição geral do software pode ser encontrada no repositório https://github.com/BrunoTas/FunnyPlaces. 


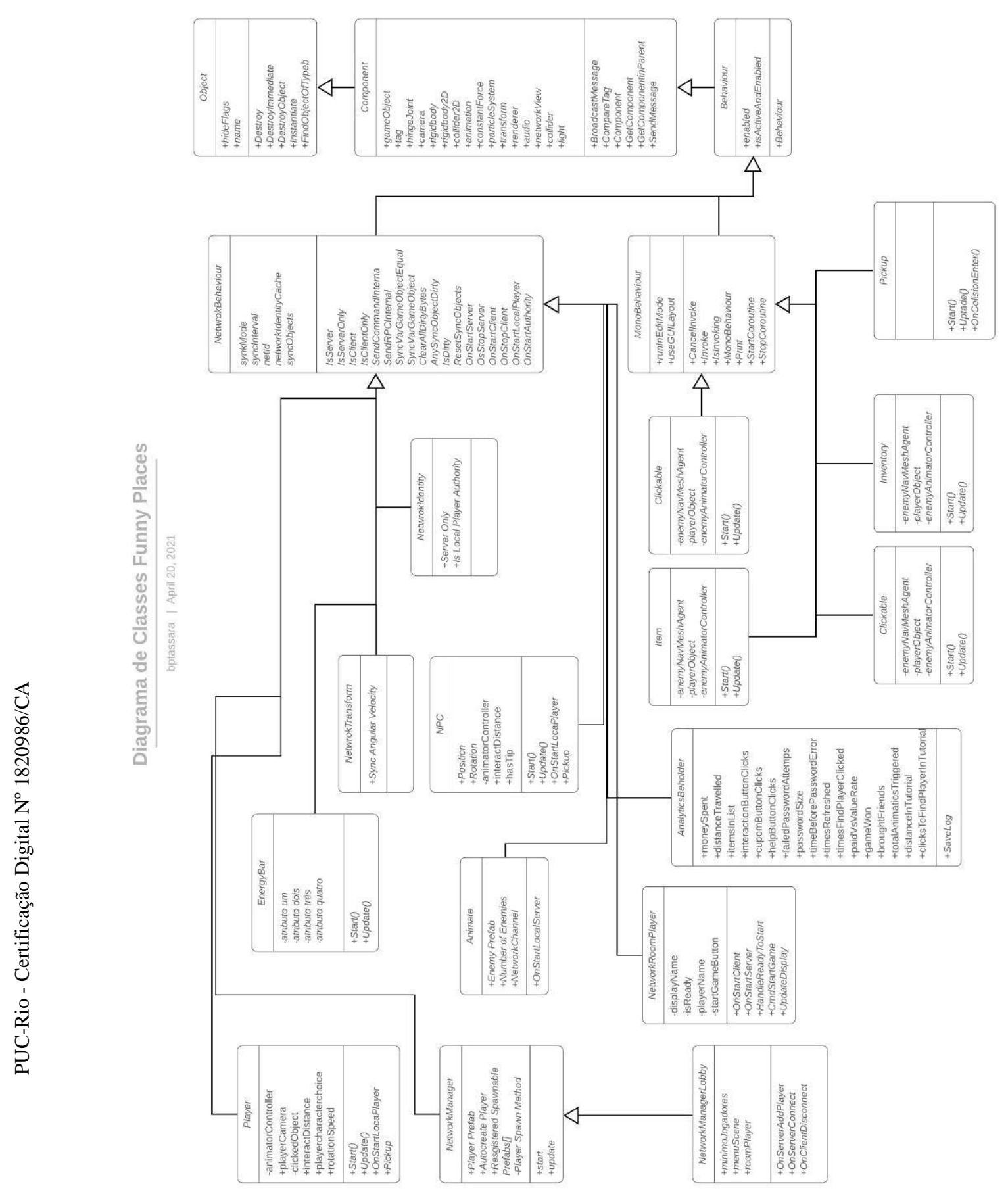

Figura 30: Diagrama de Classes (WIP)

\subsection{Scripts}

Os scripts que controlam os elementos do jogo foram programados em C\#. A seguir é mostrado um pequeno trecho da classe que implementa o controle do jogador e serve para ilustrar o tipo de codificação utilizado. Todos os scripts podem ser consultados no repositório. https://github.com/BrunoTas/FunnyPlaces. 


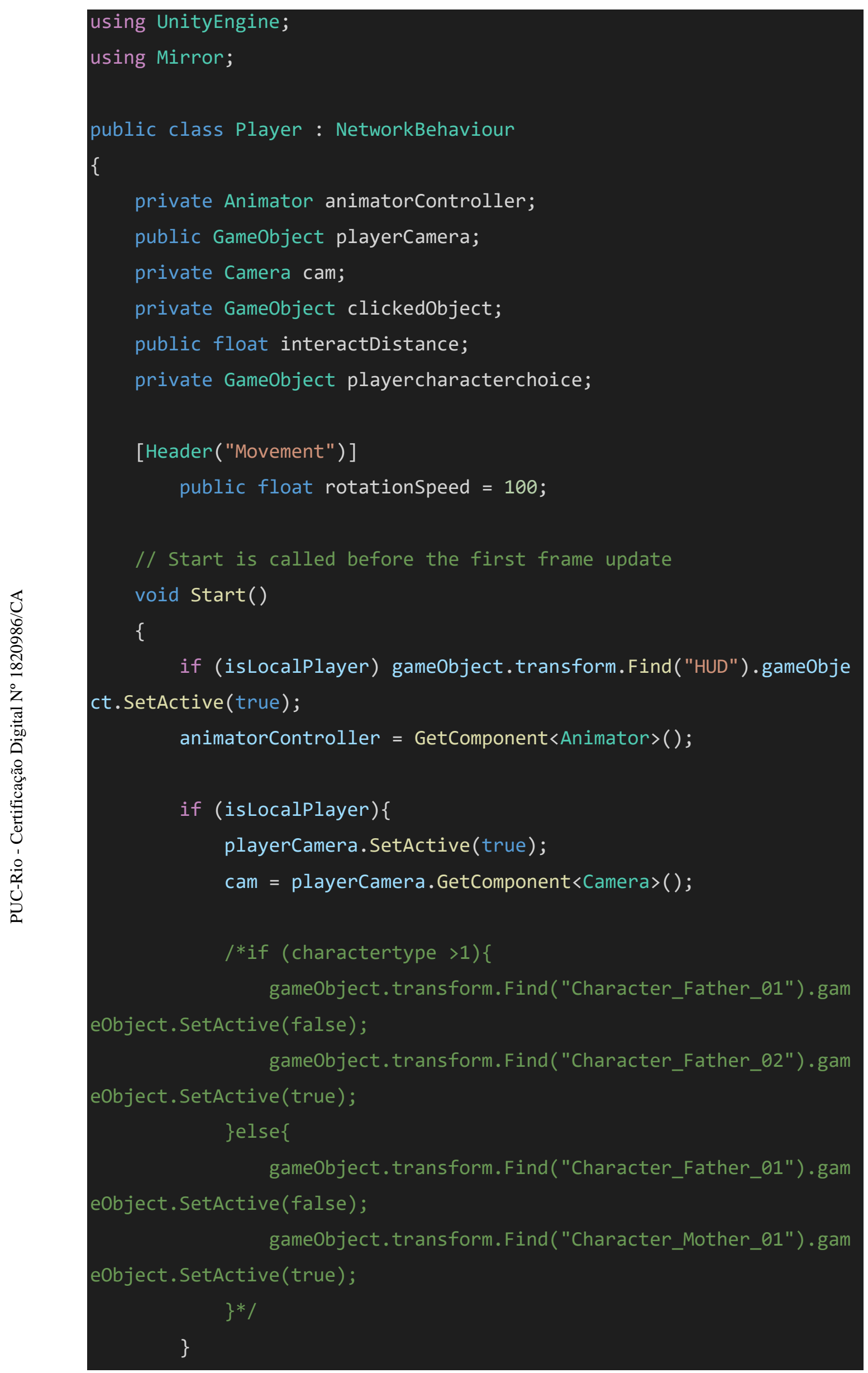




\section{\}}

// Update is called once per frame

void Update()

\{

// movement for local player

if (! isLocalPlayer) return;

/*

//movement 1

float horizontal = Input.GetAxis("Horizontal");

transform.Rotate $(\theta$, horizontal $*$ rotationspeed $*$ Time.deltaT ime, $\theta)$;

float vertical $=$ Input.GetAxis("Vertical");

Vector3 forward = transform.TransformDirection(Vector3.forwa

rd);

$* /$

//movement 2

float $x=$ Input.GetAxis("Horizontal")* Time.deltaTime *150.0f

float z = Input.GetAxis("Vertical")*Time.deltaTime *3.0f;

transform. Rotate $(\theta, x, \theta)$;

transform. Translate $(0,0, z)$;

if $(z==0)\{$

animatorController.SetBool ("iswalking", false);

animatorController.SetBool("iswalkingBackwards", false);

\}

if $(z>0)\{$

animatorController.SetBool ("iswalking", true);

animatorController.SetBool ("iswalkingBackwards", false);

\}else if $(z<\theta)\{$

animatorController.SetBool ("iswalking", false); 


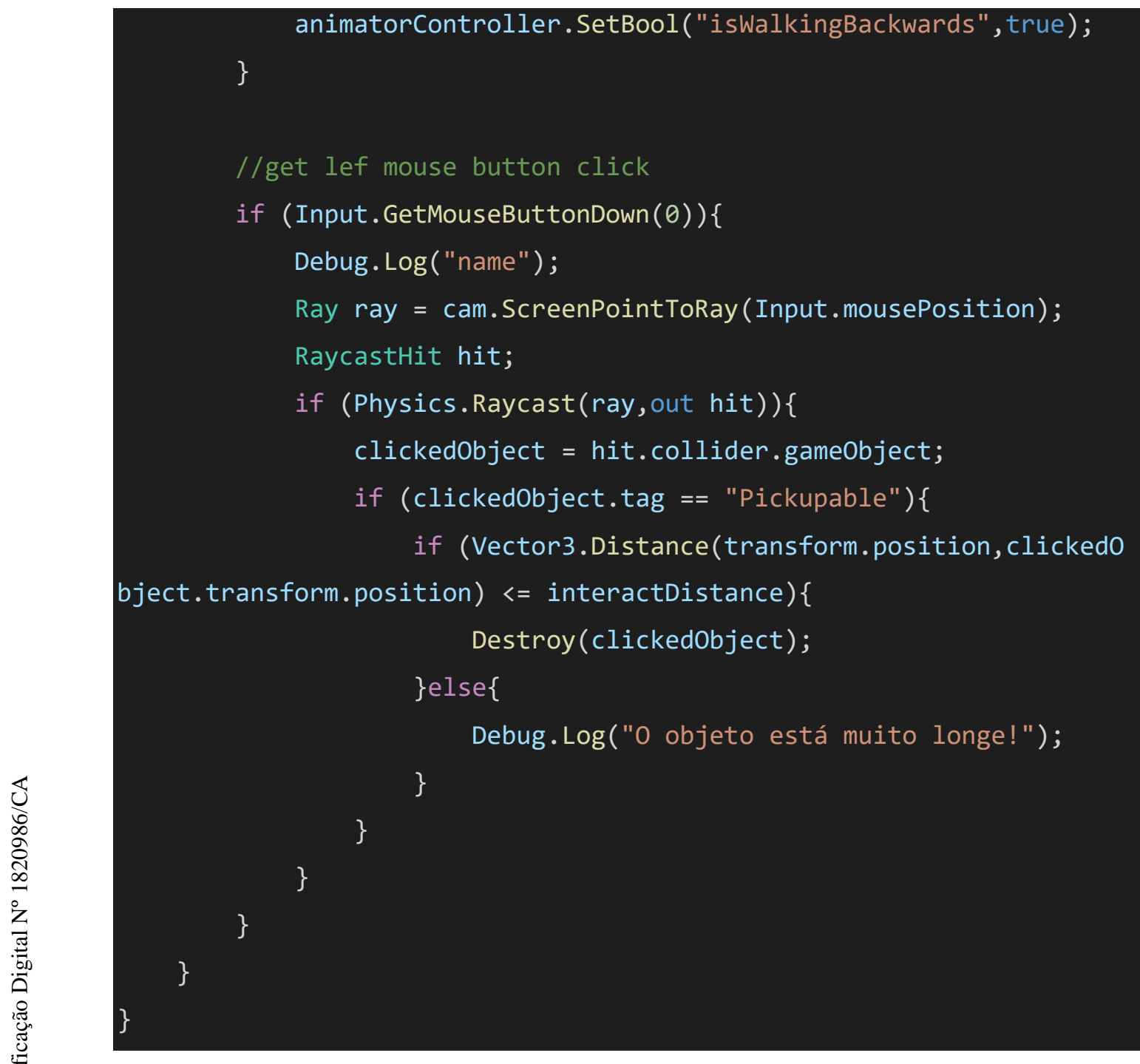

\subsection{Animações}

As animações adquiridas no site https://www.mixamo.com/ foram ajustadas para os modelos disponíveis, todos humanoides bípedes. O controlador de animação foi configurado de forma que o personagem tivesse animações para andar, girar, ficar parado e ficar parado e cansado, como mostrado na Figura 31. 


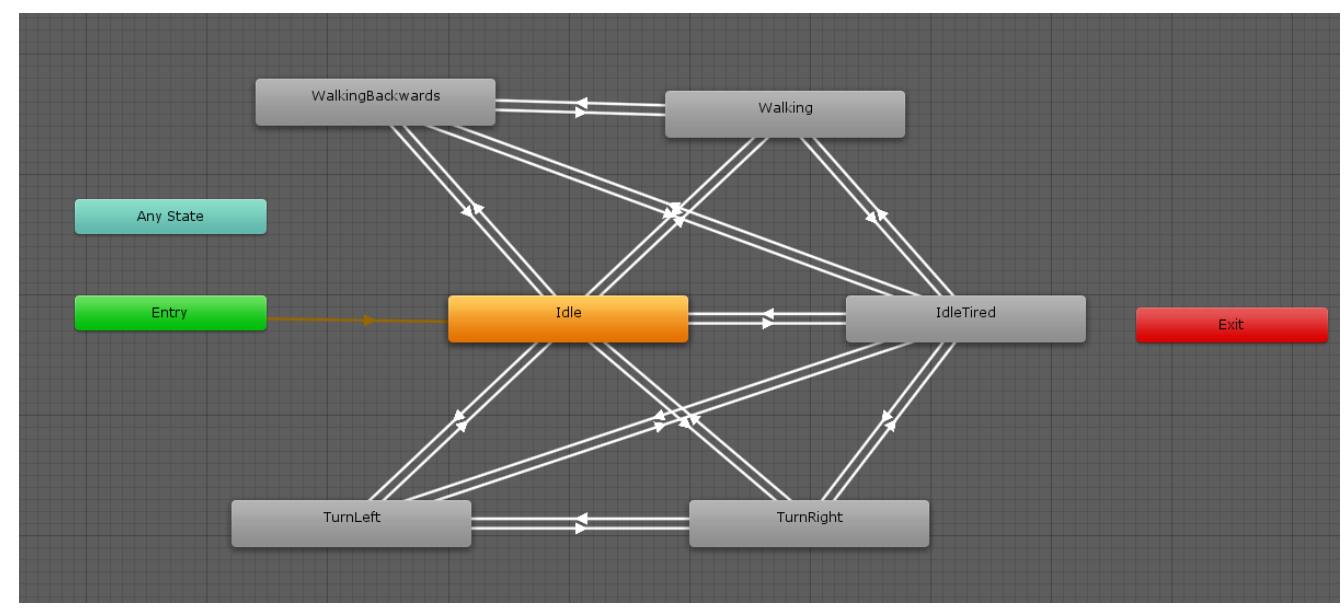

Figura 31: Controlador de Animação dos personagens dos jogadores, usando a interface do Unity 


\section{Resultados alcançados}

Em sua fase atual, o jogo apresentado nesta dissertação constitui apenas um protótipo, desenvolvido com o propósito de servir como prova de conceito para preparar uma próxima etapa de pesquisa interdisciplinar, envolvendo as áreas de Computação e Psicologia. O objetivo foi testar a tecnologia e a abordagem contextualizada para avaliar funções executivas em adultos mais velhos. Não foram feitos testes com pacientes nem com psicólogos, de modo que não há, aqui, a pretensão de avaliar métricas e interações. Esta dissertação pretendeu criar um arcabouço de jogo sério que tornasse viável a configuração de testes, situações e métricas com vistas a futuras avaliações práticas de funções executivas.

Os resultados obtidos com o protótipo de Lugares Divertidos foram promissores. Foi possível provar o domínio do ferramental necessário para viabilizar um jogo online, tendo havido sucesso em conectar mais de um computador ao servidor, tanto com os computadores na mesma rede quanto com computadores em redes diferentes. No entanto, ainda são necessários mais testes para garantir a conectividade, que pode por vezes ser perturbada pela configuração de roteadores e firewalls.

No que tange o desempenho gráfico, foi feito um teste com 3 instâncias simultâneas do jogo rodando em uma resolução full HD em um desktop (Figura 32). Foram medidos os valores de quadros por segundo, uso de CPU e GPUs (Figura 33).

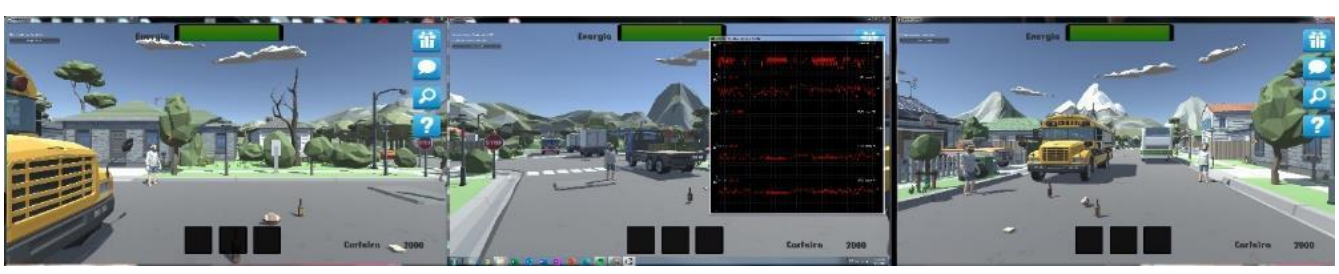

Figura 32: Teste com 3 instâncias no mesmo computador 


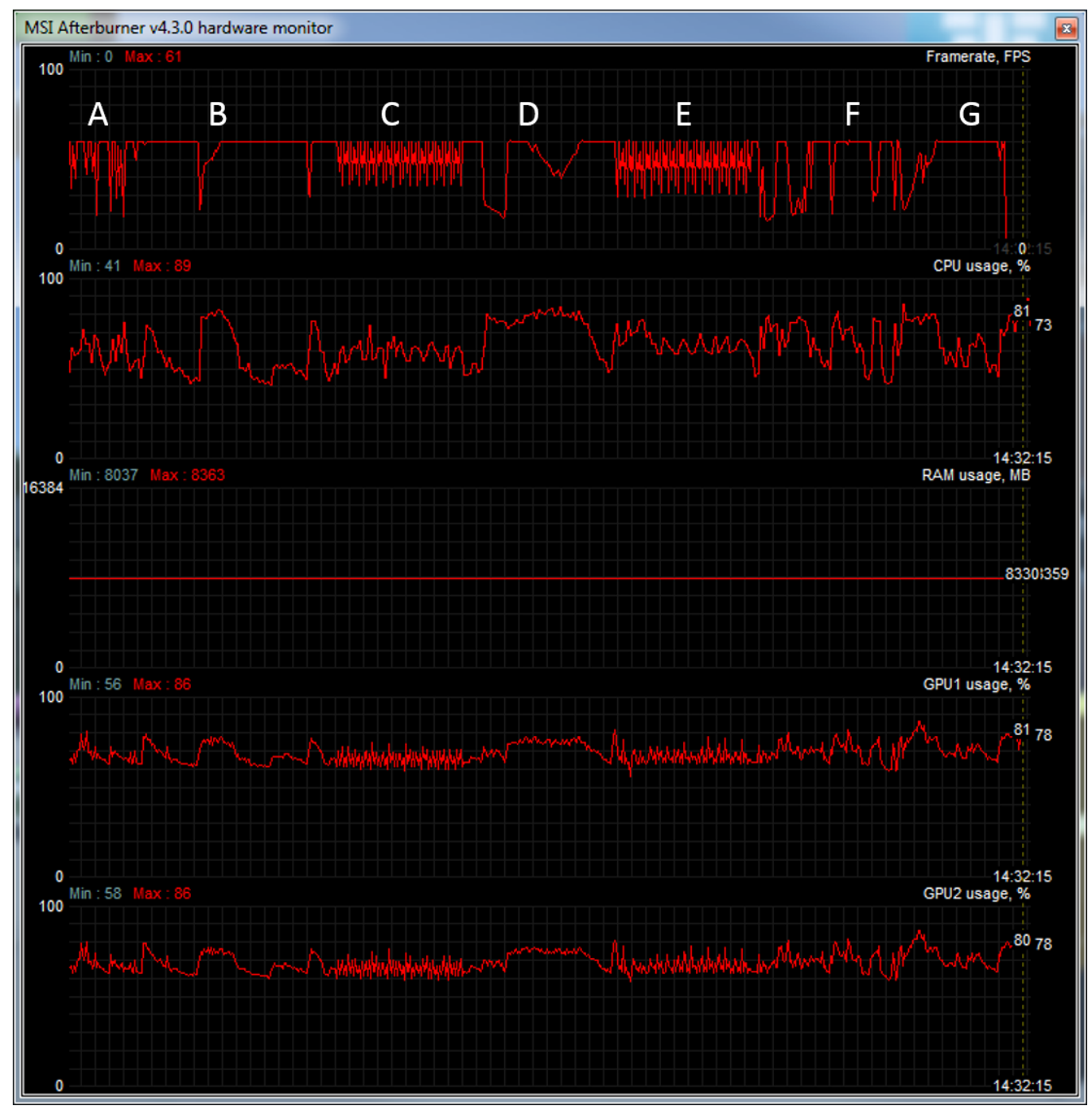

Figura 33: Desempenho Gráfico no teste com 3 instância

Para o teste de desempenho gráfico, foi usado um computador com processador Core I7, 16 GB de Ram, 2 Geforce GTX 980 em SLI e resolução de 5760 x 1080. As três instâncias foram colocadas lado a lado para forçar ao máximo o processamento. Os resultados quanto a quadros por segundo foram satisfatórios, especialmente tendo em vista a resolução estendida e o uso de placas de vídeo um pouco datadas (modelos de 2014). A Figura 33 mostra determinados momentos do jogo e o respectivo desempenho naquele momento. Baseando-se na quantidade de quadros por segundo, foram destacados alguns instantes e registrado o que o avatar do jogador fazia naquele momento:

A) Movimentação livre com giros horizontais e os outros dois jogadores aparecendo na tela. 
B) Movimentação em linha reta seguida por uma virada rápida e depois por uma caminhada longa em linha reta.

C) Giro constante para a esquerda, sem a presença de nenhum outro personagem na tela.

D) Caminhada livre pela cidade. A queda na quantidade de quadros por segundo corresponde a trechos da cidade com maior quantidade de elementos pequenos no terreno, como tufos de grama, garrafas, cadeiras e outros detalhes do cenário.

E) Giro constante para a esquerda, com a presença dos outros dois jogadores na tela.

F) Caminhada livre com outros dois personagens aparecendo na tela.

G) Caminhada em linha reta pelo meio da rua.

Apesar do desempenho satisfatório quanto à taxa de quadros por segundo, foi detectado um alto percentual de uso de CPU e GPUs, cerca de $80 \%$. Foram identificadas duas possíveis causas para esses valores elevados. A primeira é a distância de visão, que atualmente é ilimitada, ou seja, mesmo objetos muito distantes ainda são renderizados em detalhes. A segunda é o uso intenso de estruturas envolventes para colisão (chamadas de colliders no Unity) do tipo malha (mesh colliders) (Figura 34).

Para a melhoria do desempenho gráfico pode-se reduzir a qualidade dos objetos distantes e substituir os colliders do tipo malha, por colliders primitivos, como esferas e cilindros. No entanto, estas otimizações foram deixadas para uma versão futura de Lugares Divertidos. 


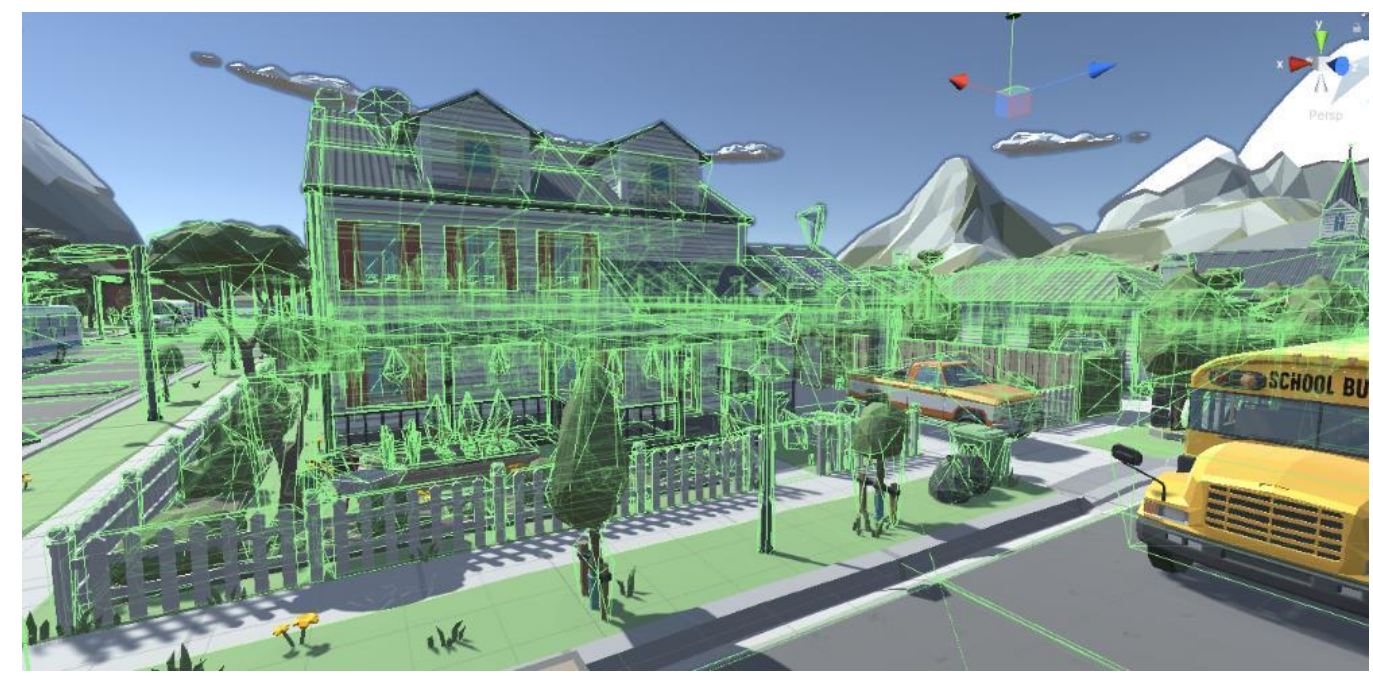

Figura 34: Uso intenso de mesh colliders, o que reduz o desempenho do processamento

Foram feitos alguns testes de conectividade, onde um computador agia como servidor e cliente e o outro como cliente. No que tange a qualidade da conexão constatou-se que o Mirror Networking não oferece ferramentas nativas de medição de latência. Como o desenvolvimento de um componente para essas medições não se justificava, a avaliação da latência foi aproximada e baseada na gravação de vídeos onde era possível ver a tela dos dois computadores, um notebook e um desktop (Figura 35). Também foi avaliada a facilidade de conexão entre os dois computadores e ainda com um computador remoto via internet. Os resultados são abordados a seguir:

- Desktop LAN x Notebook LAN - A conexão foi simples e rápida, não havendo nenhuma falha de conexão. A latência ficou em aproximadamente $0.5 \mathrm{~s}$.

- Desktop LAN x Notebook Wifi - A conexão foi igualmente simples e rápida e a latência ficou abaixo de $0.5 \mathrm{~s}$.

- Desktop Lan x Computador remoto - A conexão não foi possível.

O que mais chamou a atenção nesta etapa foi o problema na conexão com um computador remoto via internet. Este impedimento ocorreu porque, para este tipo de conexão ponto a ponto, é necessária a habilitação de um "port forwarding” por parte do equipamento que funciona como servidor ou host. $\mathrm{O}$ fato inesperado foi que a empresa provedora de internet bloqueia este tipo de prática para contratos residenciais, recomendando que para tanto seja feita a migração para um plano 
empresa com IP público!

Para o uso esperado de Lugares Divertidos no estágio atual de desenvolvimento, a conectividade de computadores na mesma rede atende perfeitamente às necessidades do projeto. Caso as versões futuras do jogo venham a ser disponibilizadas para o público em geral, seja em versão desktop seja em versão mobile, haverá necessidade de se usarem servidores dedicados e um sistema de matchmaking. A ferramenta, ou asset, responsável por estas funcionalidades, já foi adquirida, e chama-se Dedicated Server Kit. Este asset foi desenvolvido pelo Viz2K Studios, especialmente para ser usado em conjunto com o Mirror Networking.

A funcionalidade de se conectar remotamente com o computador que age como servidor de Lugares Divertidos pode ser útil na medida em que um idoso poderia conectar-se remotamente para participar de uma partida. Provavelmente, utilizando a rede da PUC-Rio, seja com um IP público ou com um port forwading, será possível, para um psicólogo agindo como controlador do jogo em um servidor no Departamento de Psicologia, receber conexões de idosos que poderiam jogar sem sair de suas casas.

Quanto à latência, para o tipo de jogo que é Lugares Divertidos, 500 milissegundos é perfeitamente aceitável. 


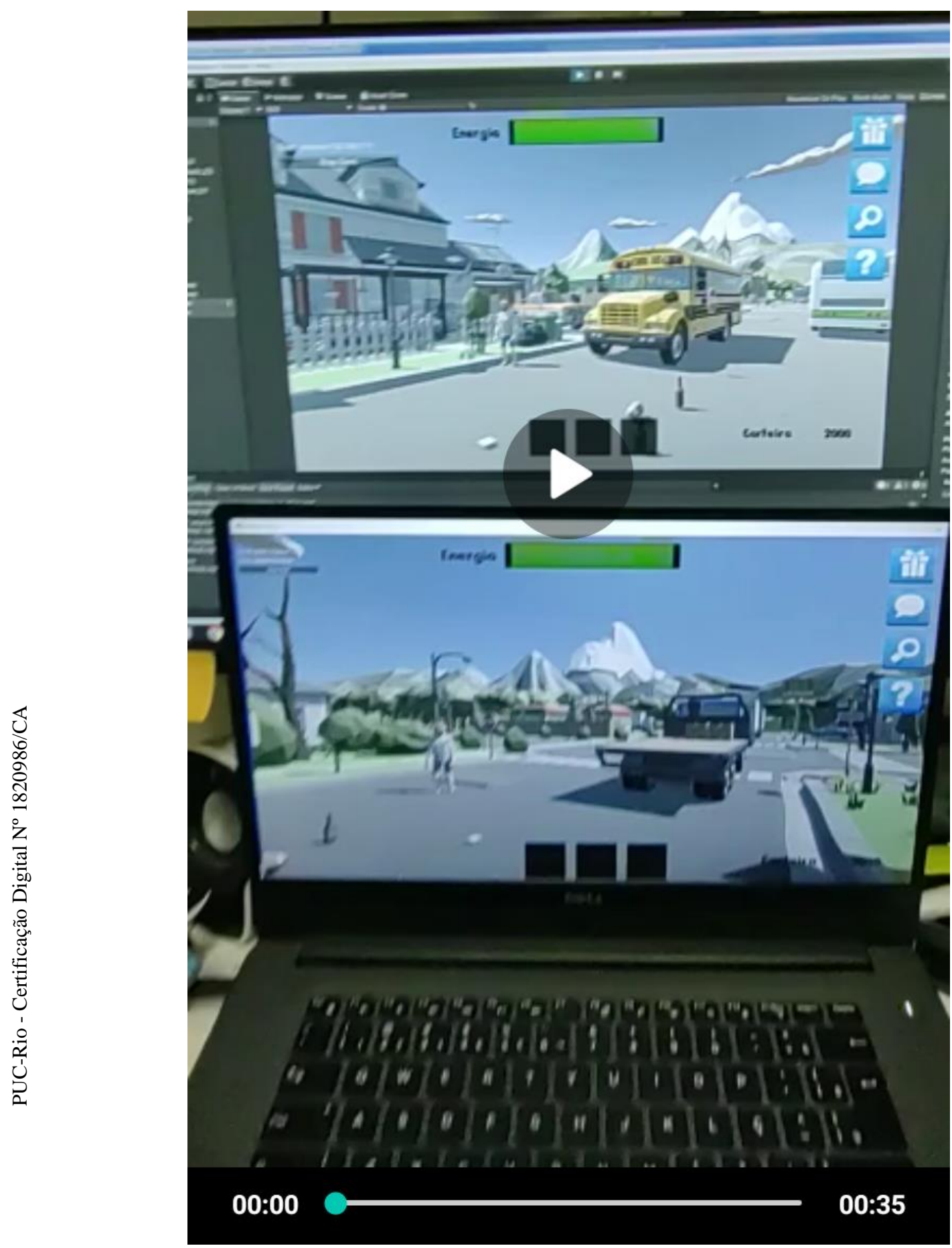

Figura 35: Teste de latência

Outro resultado apurado foi o relato de um jogador experiente. Foi pedido ao jogador que iniciasse duas instâncias do jogo e conectasse uma na outra; em seguida, ele deveria apenas se movimentar pelo mapa e descrever suas impressões em tempo real. O relato encontra-se aqui transcrito:

- Achei lenta a velocidade de movimentação para frente e para trás. 
- A movimentação lateral de giro me incomodou um pouco, pois pareceu começar mais devagar e depois acelerar. Acho que isso pode incomodar pessoas não muito acostumadas.

- A animação está fluida.

- A cidade é muito bonita.

- Estou sentindo falta de uma trilha sonora e dos sons dos passos.

- Gostei do pássaro voando.

- Senti falta de poder olhar para cima e para baixo.

Espera-se colher mais relatos do uso do jogo por algum idoso e, futuramente, expor um grupo de jogadores experientes e um grupo de idosos a uma partida completa. 


\section{Conclusões e Trabalhos Futuros}

\subsection{Conclusões}

A grande quantidade de trabalhos combinando jogos e avaliações psicológicas, inclusive de funções executivas, mostra que a parceria entre as áreas de psicologia e informática foi desde há longo tempo identificada como promissora, apenas se confirmando pelo trabalho aqui apresentado. Entretanto, muitos daqueles outros trabalhos realizaram apenas a digitalização de testes clássicos da psicologia e da neuropsicologia, ou então se apoiaram em jogos muito simples. Lugares Divertidos vai além desta simplicidade, provendo mecanismos de avaliação das funções executivas que são ao mesmo tempo, complexos, transparentes e imbuídos de contexto, desta forma estendendo a funcionalidade do jogo.

Com a presente modelagem conceitual do jogo Lugares Divertidos e contando com as futuras melhorias na sua implementação e com a testagem intensa em pacientes, espera-se ir além do estado da arte (Valladares (12) e Kraczyk (15)). Para tanto, além de uma abordagem repleta de contexto, que aborda atividades relacionadas ao dia a dia, o jogo se vale de um grande número de variáveis coletadas, métricas para avaliar funções executivas individuais, possibilidade de configuração e adaptação dos testes por parte do controlador ou psicólogo e da socialização, pois trata-se de um jogo multijogador online.

A importância da interação social para a saúde mental do indivíduo, amplamente reconhecida e aqui retratada pela grande quantidade de referências a trabalhos sobre o tema, encontra-se também presente em Lugares Divertidos, fazendo dele uma opção suficiente para uma posterior aplicação focada no tratamento e melhoria das funções executivas e qualidade de vida dos idosos. Não foi encontrado nenhum outro trabalho envolvendo jogos que tivesse abordado de modo tão completo essa dimensão de multijogador, o que corrobora o caráter inovador de Lugares Divertidos.

Somada a estas considerações, a possibilidade de o psicólogo configurar o jogo, com o nível de detalhes disponibilizado já no protótipo, garante o interesse prático 
do projeto.

A implementação de um jogo multijogador online, no entanto, não vem apenas com benefícios. O nível de complexidade dos sistemas envolvidos neste tipo de jogo cria dificuldades que não seriam encontradas em jogos single player, como por exemplo a necessidade de animações suaves tanto para o jogador local quanto para o remoto, a necessidade de sincronizar variáveis, ou ainda de disparar comportamentos no cliente ou rotinas no servidor.

Para apoiar todas estas etapas a escolha do asset Mirror Networking se mostrou bem acertada, pois a solução não tem custo inicial, tem escalabilidade e pode, a um custo relativamente baixo (U\$60), ser aplicada a uma estrutura de servidor dedicado com salas de jogos, modelo que vem se tornando cada vez mais comum atualmente.

Espera-se com este trabalho fornecer as bases para um jogo sério (serious game) que auxilie o diagnóstico e o treinamento de comprometimento cognitivo leve (CCL), através da consideração de funções executivas de forma inovadora incluindo a interação social e colaborativa para a conclusão das missões. Acreditase que a forma lúdica de trabalho inerente ao mundo dos jogos permita que os idosos se engajem na atividade de forma natural e prazerosa, sem que fiquem explícitos os procedimentos de diagnóstico/treinamento e sem que se imponham atividades repetitivas e tediosas, como costuma acontecer em testes cognitivos convencionais e em minijogos mentais.

\subsection{Trabalhos Futuros}

Muitas são as possibilidades para os trabalhos futuros envolvendo Lugares Divertidos. Para as próximas versões do jogo, espera-se poder avaliar mais funções executivas, tais como o uso de um medidor de batimentos cardíacos ou de expressões faciais (44) para avaliar o autocontrole emocional do jogador. Há a possibilidade de incorporar técnicas de planning e storytelling, fazendo com que o jogo se adapte ao jogador para prover experiência mais personalizada, como em (48) e (49).

Pode-se aumentar a quantidade de variáveis coletadas e utilizar aprendizado de 
máquina para prever indícios precoces de decaimento cognitivo, como no trabalho de Valadares (12). A aplicação de testes clássicos de funções executivas em indivíduos que participem do jogo pode ajudar a calibrar melhor os algoritmos de avaliação das funções executivas. A configuração do experimento por parte do psicólogo pode evoluir, permitindo que ele selecione ainda mais características do jogo, por exemplo um cenário diferente, levando os jogadores para um ambiente espacial, futurista, ou de cidade grande ou mesmo de fazenda. Além disso, há a possibilidade de se construir um catálogo de missões e permitir que seja feita a seleção de quais delas comporiam o jogo.

Há a possibilidade de utilizar dispositivos de ECG portáteis (Emotiv®) e medir a ativação das regiões do cérebro durante uma partida. Podem ser implementados tipos mais emocionantes de imprevistos no jogo, como por exemplo um incêndio em uma loja ou a presença de batedores de carteira, que, ao se aproximarem dos jogadores, reduzem o dinheiro disponível na carteira do personagem. É possível implementar o jogo em pareceria com uma empresa e, a partir do desempenho dos funcionários, mapear quais funções executivas cada um poderia desenvolver melhor, tornando-os mais saudáveis mentalmente e mais eficientes em suas atividades.

Pode-se ainda realizar estudos que avaliem se partidas regulares de Lugares Divertidos teriam um efeito benéfico para desenvolver as funções executivas dos idosos. O jogo pode ser disponibilizado em outras clínicas além da clínica de psicologia da PUC-Rio, permitindo uma coleta ainda maior de dados, que poderiam integrar um grande banco de dados com resultados de partidas de Lugares Divertidos. Estes dados poderiam alimentar algoritmos de aprendizado de máquina para melhora a identificação e possível diagnóstico do comprometimento cognitivo leve. O uso de ambientes virtuais de rede (Networked Virtual Environments) pode aumentar ainda mais a imersão no jogo e ajudar idosos com problemas de socialização a interagirem mais e melhor.

Espera-se ainda, em uma instalação futura do jogo, aumentar a quantidade de dados coletados com propósitos de Game Analytics, permitindo uma melhor medição de performance e servindo de base para algoritmos de aprendizado de máquina (machine learning). Estes algoritmos poderiam simular um jogador real, com ou sem déficit cognitivo, e identificar padrões que ajudem na medição, treinamento e 
diagnóstico do comprometimento cognitivo. Os mesmos algoritmos poderiam inclusive ser aplicados para, a partir de dados do jogo atual, selecionar o tipo de imprevisto ou ajuste em mecânica do jogo que venha a maximizar o treinamento de uma função executiva específica.

É animador observar que não faltam possibilidades para diversos trabalhos futuros com Lugares Divertidos, sempre a cargo de uma equipe interdisciplinar envolvendo Informática e Psicologia. 


\section{Referências}

1. M, Camarano A. Envelhecimento da População Brasileira: uma Contribuição Demográfica, Texto par Discussão 858 -IPEA (Instituto de Pesquisa Ecconômica Aplicada). 2002.

2. Kanasi E, Ayilavarapu S, Jones J. The aging population: demographics and the biology of aging. Periodontol 2000. Outubro de 2016, pp. 13-8.

3. Fichman, Helenice Charchat, Fernandes, Conceição Santos, Oliveira, Rosinda Martins, Caramelli, Paulo, Aguiar, Daniele, \& Novaes, Regina. Predomínio de Comprometimento Cognitivo Leve Disexecutivo em idosos atendidos no ambulató-rio da geriatria de um hospital público terciário na cidade do Rio de Janeiro. Neuropsicologia Latinoamericana. 2013, pp. 31-40.

4. Fichman H C, Caramelli, Paulo, Sameshima, Koichi, \& Nitrini, Ricardo. Declínio da capacidade cognitiva durante o envelhecimento. Brazilian Journal of Psychiatry, 27(1). 2005, pp. 79-82.

5. A, Diamond. Executive functions. Annual Review of Psychology 64. 2013, pp. 135-168.

6. Neuropsicologia [Notas de Aula]. Departamento de Psicologia PUC-Rio. C, Fichman H. 2020.

7. Sternberg, R. J., \& Mio, J. S. Cognitive psychology. s.I. : Cengage Learning/Wadsworth, 2009.

8. M, Oliveira R. . Abordagem Cognitiva da Compreensão Leitora: implicações para a educação e práti-ca clínica. Interação em Psicologia (Online), v. 18. pp. 397-406.

9. Martha Ann Bell, Tatiana Garcia Meza. Executive Function. [A. do livro] Janette B. Benson. Encyclopedia of Infant and Early Childhood Development. s.I. : Elsevier, 2020.

10. MOGRABI, D. C., et al. Relationship between activities of daily living and cognitive ability in a sample of older adults with heterogeneous educational level . Annals of Indian Academy of Neurology. Janeiro de 2014, pp. 17(1):71-76.

11. Doebel, Sabine. How your brain's executive function workds - and how to improve it. TED Talk. https://www.ted.com. [Online] Dezembro de 2018.

https://www.ted.com/talks/sabine_doebel_how_your_brain_s_executive_fu nction_works_and_how_to_improve_it/transcript. 
12. Valladares-Rodriguez $S$, Pérez-Rodriguez R, Fernandez-Iglesias JM, Anido-Rifón LE, Facal D, Rivas-Costa C. Learning to Detect Cognitive Impairment through Digital Games and Machine Learning Techniques. Methods of Information in Medicine. Setembro de 2018, pp. 57(4):197-207.

13. Bonnechère $B$, Van Vooren $M$, Bier JC, De Breucker $S$, Van Hove $O$, Van Sint Jan S, Feipel V, Jansen B. The Use of Mobile Games to Assess Cognitive Function of Elderly with and without Cognitive Impairment. Journal of Alzheimers Disease. 2018, pp. ;64(4):1285-1293.

14. Jirayucharoensak $S$, Israsena $P, P a n-N g u m ~ S$, Hemrungrojn $S$, Maes $M$. A game-based neurofeed-back training system to enhance cognitive performance in healthy elderly subjects and in patients with amnestic mild cognitive impairment. Clinical Interventions in Aging. Fevereiro de 2019, pp. 14:347-360.

15. Krawczyk DC, Han K, Martinez D, Rakic J, Kmiecik MJ, Chang Z, Nguyen L, Lundie M, Cole RC, Nagele M, Didehbani N. Executive Function Training in chronic traumatic brain injury patients: study protocol. Trials. 20, 2019, Vol. 435.

16. Jocelyn Parong, Richard E. Mayer, Logan Fiorella, Andrew MacNamara, Bruce D. Homer, Jan L. Plass. Learning executive function skills by playing focused video games. Contemporary Educational Psychology. 2017, Vol. 51, pp 141-151.

17. Hagler S, Jimison HB, Pavel M. Assessing executive function using a computer game: computational modeling of cognitive processes. Journal of Biomed and Health Informatics. 18, 2014, Vol. 4, pp 1442-1452.

18. Johann VE, Karbach J. Validation of new online game-based executive function tasks for children. Journal of Experimental Child Psychology. Dezembro de 2018, pp. 176:150-161.

19. Tong $T$, Chignell $M$, DeGuzman CA. Using a serious game to measure executive functioning: response inhibition ability. Applied Neuropsychology Adult. Novembro de 2019, pp. 12:1-12.

20. Chicchi Giglioli IA, de Juan Ripoll C, Parra E, Alcañiz Raya M. Are 3D virtual environments better than 2D interfaces in serious games performance? An explorative study for the assessment of executive functions. Applied Neuropsychology Adult. Março de 2021, pp. 28(2):148157.

21. Kuiper JS, Zuidersma M, Oude Voshaar RC, Zuidema SU, van den Heuvel ER, Stolk RP, Smidt N. Social relationships and risk of dementia: A systematic review and meta-analysis of longitudinal cohort studies. Ageing Research Reviews. Julho de 2015, pp. 22:39-57.

22. National Research Council (US) Committee on Aging Frontiers in Social Psychology, Personal-ity, and Adult Developmental Psychology; 
Carstensen LL, Hartel CR. When I'm 64. National Academies Press. 2006, pp. 5, Social Engagement.

23. Antonucci, T. C. Social relations: An examination of social networks, social support, and sense of control. [ed.] In J. E. Birren \& K. W. Schaie. Handbook of the psychology of aging. s.l. : Academic Press, 2001, pp. p. 427-453.

24. Bowling, A., \& Grundy, E. The association between social networks and mortality in later life. Reviews in Clinical Gerontology. 1998, pp. 8(4): 353-361.

25. Berkman, L. F. The relationship of social networks and social support to morbidity and mortality. [ed.] In S. Cohen \& S. L. Syme. Social support and health. s.l. : Academic Press, 1985, pp. 241-262.

26. Vaillant, G. E., Meyer, S. E., Mukamal, K., \& Soldz, S. Are social supports in late mid-life a cause or a result of successful physical ageing? Psychological Medicine. 1998, pp. 28(5): 1159-1168.

27. Antonucci TC, Fuhrer R, Dartigues JF. Social relations and depressive symptomatology in a sample of community-dwelling French older adults. Psychology and Aging. Março de 1997, pp. 12(1):189-195.

28. Bassuk SS, Glass TA, Berkman LF. Social disengagement and incident cognitive decline in community-dwelling elderly persons. Ann Intern Med. Agosto de 1999, pp. 131(3):165-73.

29. Arbuckle TY, Gold DP, Andres D, Schwartzman A, Chaikelson J. The role of psychosocial context, age, and intelligence in memory performance of older men. Psychology and Aging. Março de 1992, pp. $7(1): 25-36$.

30. Neuropsicologia - Wikipédia, a enciclopédia livre. pt.wikipedia.org. [Online] [Citado em: 05 de 04 de 2021.] https://pt.wikipedia.org/wiki/Neuropsicologia.

31. Cohen RA, Marsiske MM, Smith GE. Neuropsychology of Aging. [A. do livro] Michael J. Aminoff/ François Boller. 2019, Vols. 149-180.

32. Video - Normal Brain vs. Alzheimer's. Dementia Care Central. [Online] [Citado em: 01 de Janeiro de 2021.] https://www.dementiacarecentral.com/video/video-brain-changes/.

33. Fichman, Helenice Charchat, Oliveira, Rosinda Martins, \& Fernandes, Conceição Santos. Neuropsychological and neurobiological markers of the preclinical stage of Alzheimer's disease. Psychology \& Neuroscience. 2011, pp. 4(2), 245-253. 
34. UEHARA, E., Charchat, H e FERNAN-DES, J. L. Funções executivas: um retrato integrativo dos principais modelos e teorias deste conceito. Neuropsicologia Latinoamericana. 2013, pp. v. 5, p. 25-37.

35. Landeira, $\mathrm{J}$, et al. Working memory and mathemathical thinking: a cognitive and effective neuroscience approach. Jornal Internacional de Estudos em Educação Matemátic. 2015.

36. Malloy - Diniz L F, Fuentes D., Mattos P, Abreu N et al. Avaliação Neuropsicológica. s.I. : Artes Médicas, 2010.

37. Brown-Peterson Task - Wikipedia. Wikipedia. [Online] 17 de Março de 2021. [Citado em: 12 de Junho de 2021.] https://en.wikipedia.org/wiki/Brown\%E2\%80\%93Peterson_task.

38. Memory span - Wikipedia. Wikipedia. [Online] 13 de Março de 2021. [Citado em: 12 de Junho de 2021.] https://en.wikipedia.org/wiki/Memory_span.

39. Buttelmann F, Karbach J. Development and Plasticity of Cognitive Flexibility in Early and Middle Childhood. Fronttiers in Psychology. Junho de 2017, p. 8:1040.

40. S, Monsell. Task switching. Trends in Cogn Science. Março de 2003, pp. 7(3):134-140.

41. Colé $P$, Duncan LG, Blaye A. Cognitive flexibility predicts early reading skills. Frontiers in Psychology. Junho de 2014, p. 5:565.

42. Nihal Yeniad, Maike Malda, Judi Mesman, Marinus H. van IJzendoorn, Suzanne Pieper. Shifting ability predicts math and reading performance in children: A meta-analytical study. Learning and Individual Differences. 2013, pp. Volume 23, Pages -9.

43. Porteus Maze Test - Wikipedia. Wikipedia. [Online] 19 de Janeiro de 2021. [Citado em: 13 de Junho de 2021.] https://en.wikipedia.org/wiki/Porteus_Maze_test.

44. Cunha GM. Real time Emotion Recognition Based on Images Using ADM and SVM. Tese orientada pelo professor Feijo $B$.

45. S, De Lima E, B, Feijó e L, Furtado A. Player behavior and personality modeling for interactive storytelling in games. Entertainment Computing. 2018, pp. v. 28, p. 32-48.

46. F, Bicalho L, A, Baffa e B, Feijó. A Game Analytics Model to Identify Player Profiles in Singleplayer Games. Rio de Janeiro : s.n., 2019. 18th Brazilian Symposium on Computer Games and Digital Entertainment (SBGames). Vol. 1, pp. 11-20. 
47. Mirror Networking. Mirror Networking. [Online] https://mirrornetworking.com/.

48. de Lima, E S, B, Feijó e L, Furtado A. Procedural Generation of Quests for Games Using Genetic Algorithms and Automated Planning. Rio de Janeiro : s.n., 2019. 18th Brazilian Symposium on Computer Games and Digital Entertain-ment (SBGames). pp. 144-153.

49. de Lima E S, Feijó B, Furtado A L e M, Gottin V. Personality and Preference Modeling for Adaptive Storytelling.. Foz do Iguaçú : s.n., 2018. 17th Brazilian Symposium on Computer Games and Digital Entertainment (SBGames), 2018.

50. Mograbi DC, Faria Cde A, Fichman HC, Paradela EM, Lourenço RA. Relationship between activi-ties of daily living and cognitive ability in a sample of older adults with heterogeneous educational level. Ann Indian Acad Neurol. Jan de 2014 Jan; pp. 71-6.

51. Nitrini R, Lefèvre $B H$, Mathias $S C$, Caramelli $P$, Carrilho $P E$, Sauaia $N$, Massad E, Takiguti C, Da Silva IO, Porto CS, et al. Neuropsychological tests of simple application for diagnosing dementia. Arquivos de Neuropsiquiatria. Dezembro de 1994, pp. 52(4):457-465.

52. Boroń, M., Brzeziński, J. \& Kobusińska. A P2P matchmaking solution for online games. Peer-to-Peer Network Applications. 2020, pp. Vol. 13: 137-150.

53. Arbuckle TY, Gold DP, Andres D, Schwartzman A, Chaikelson J. The role of psychosocial context, age, and intelligence in memory performance of older men. Psychology and Aging. Março de 1992, pp. $7(1): 25-36$.

54. Kirova AM, Bays RB, Lagalwar S. Working memory and executive function decline across normal aging, mild cognitive impairment, and Alzheimer's disease. Biomed Research International. Outubro de 2015, p. 2015:748212. 